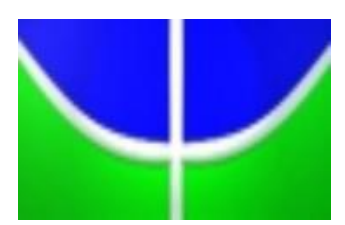

UNIVERSIDADE DE BRASÍLIA

FACULDADE DE AGRONOMIA E MEDICINA VETERINÁRIA PROGRAMA DE PÓS-GRADUAÇÃO EM AGRONOMIA

OZONIZAÇÃO COMO MÉTODO ALTERNATIVO NA CONSERVAÇÃO DE MORANGO PRODUZIDO EM SISTEMA ORGÂNICO

SABRINA MAGALY NAVAS CAJAMARCA

DISSERTAÇÃO DE MESTRADO EM AGRONOMIA 


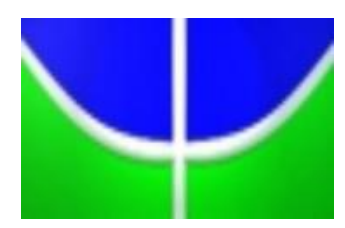

UNIVERSIDADE DE BRASÍLIA

FACULDADE DE AGRONOMIA E MEDICINA VETERINÁRIA PROGRAMA DE PÓS-GRADUAÇÃO EM AGRONOMIA

OZONIZAÇÃO COMO MÉTODO ALTERNATIVO NA CONSERVAÇÃO DE MORANGO PRODUZIDO EM SISTEMA ORGÂNICO

SABRINA MAGALY NAVAS CAJAMARCA

ORIENTADOR: DR. ERNANDES RODRIGUES DE ALENCAR

CO-ORIENTADORA: DRA. ANGELA PATRICIA SANTANA

DISSERTAÇÃO DE MESTRADO EM AGRONOMIA

PUBLICAÇÃO: 86

BRASÍLIA/DF

FEVEREIRO/2015 


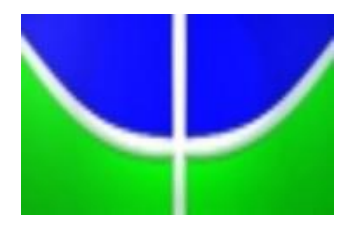

UNIVERSIDADE DE BRASÍLIA

FACULDADE DE AGRONOMIA E MEDICINA VETERINÁRIA PROGRAMA DE PÓS-GRADUAÇÃO EM AGRONOMIA

\section{OZONIZAÇÃO COMO MÉTODO ALTERNATIVO NA CONSERVAÇÃO DE MORANGO PRODUZIDO EM SISTEMA ORGÂNICO}

SABRINA MAGALY NAVAS CAJAMARCA

DISSERTAÇ̃̃̃O DE MESTRADO SUBMETIDA AO PROGRAMA DE PÓSGRADUAÇÃ̃O EM AGRONOMIA, COMO PARTE DOS REQUISITOS NECESSÁRIOS À OBTENÇÃO DO GRAU DE MESTRE EM AGRONOMIA.

APROVADA POR:

ERNANDES RODRIGUES DE ALENCAR, Dr. Professor Adjunto UnB - FAV (Orientador )/CPF: 900.558.021-68/e-mail: ernandesalencar@unb.br

MICHELLE SOUZA VILELA

(Examinador Interno)/ CPF: 919623401-63/e-mail: michellevilelaunb@ gmail.com

STHER MARIA LENZA GRECO

(Examinador Externo)/CPF: 877125471-49/e-mail: sther@ifb.edu.br

Instituto Federal de Brasília 


\section{FICHA CATALOGRÁFICA}

Cajamarca, Sabrina Magaly Navas

Ozonização como método alternativo na conservação de morango produzido em sistema orgânico./ Sabrina Magaly Navas Cajamarca; orientação de Ernandes Rodrigues Alencar. - Brasília, 2015.

104 p.:il.

Dissertação de Mestrado (M) - Universidade de Brasília/Faculdade de Agronomia e Medicina Veterinária, 2015.

1.Ozonizacao. 2. Morango. 3. Propriedades fisico-quimicas e microbiologicas

Ernandes, R. A.Ph.D

\section{REFERÊNCIA BIBLIOGRÁFICA}

CAJAMARCA, S. M. N. Ozonização como método alternativo na conservação de morango produzido em sistema orgânico. Brasília: Faculdade de Agronomia e Medicina Veterinária, Universidade de Brasília, 2015, 102p. Dissertação de Mestrado.

\section{CESSÃO DE DIREITOS}

NOME DO AUTOR: Sabrina Magaly Navas Cajamarca

TÍTULO DA DISSERTAÇÃO: Ozonização como método alternativo na conservação de morango produzido em sistema orgânico

GRAU: Mestre ANO: 2015

É concedida à Universidade de Brasília permissão para reproduzir cópias desta dissertação de mestrado para única e exclusivamente propósitos acadêmicos e científicos. $\mathrm{O}$ autor reserva para si os outros direitos autorais, de publicação. Nenhuma parte desta dissertação de mestrado pode ser reproduzida sem a autorização por escrito do autor. Citações são estimuladas, desde que citada à fonte.

Nome: Sabrina Magaly Navas Cajamarca

CPF: 704.161.371-21

Endereço: Colina Bloco K - Asa norte - Brasília/DF

CEP: 70.910-900

Tel: (61) 9616-6820 / e-mail: sabrinacajamarca@gmail.com 
DEDICATORIA

Com o amor mais puro que tem existido na faz da terra A minha Mãe Maria pessoa cheia da graça de Deus A meu Pai Luis, irmãos, irmãs, sobrinhas, sobrinhos e amigos junto com eles temos caminhado e construído o verdadeiro gozo 


\section{AGRADECIMENTOS}

Ao Padre Criador que sempre revelou-se para mim do jeito mais simples

À Universidade de Brasília (UnB), Programa de pós-graduação em agronomia pelo apoio institucional e a oportunidades de cursar o mestrado, e à Coordenação de Aperfeiçoamento de Pessoal de Nível Superior (CAPES), pela bolsa de estudo.

Ao professor Ernandes Rodrigues de Alencar pela orientação e valiosos ensinamentos para o desenvolvimento do meu trabalho.

À professora Angela Patricia Santana pela ajuda e confiança.

Ao Professor Luiz Eduardo Bassay Blum pela valiosa colaboração.

A Nara pelo ensinamento e paciência

Ao Marcio pela grande disposição e ajuda

A todos os funcionários dos laboratórios Lamal e Alimentos que compartilharam o trabalho e amizade durante este tempo.

Ao produtor rural de Brazilandi Rogimar que gentilmente ajudo neste trabalho A todos os professores que compartilharam os seus conhecimentos. e a amizade A minha grande Mãe Maria que é a minha luz, a meu Pai que confio em mim, A meus irmãos Freddy, Jenny, Ligia, Patricio, Cristian, Adriana, Andresito, que sempre se orgullaram de mim a meus lindos sobrinhos, Alvarito, Dani, Pame, Alex, Matias e o bebê alegria da minha vida a meus cunhados Mercedes, Paulino e Gabriela pelo carinho compartido.

As meus amigos Débora e Jorge Ricardo que compartilharam para mim o seu amor e grande família,

A minhas amigas Carla e Alejandra, que fizeram que o curso seja muito valioso.

As minhas Amigas Suzi e Julia companheiras da vida e a Flivia que me é como uma irmã presente de Deus.

A Rut e Samara amigas da vida pessoas que acreditaram em mim com muito amor.

A Ludovico Eunaudi e Gustavo Cerati e Cristhiam

A Shakti Ma uma pessoa muito especial na minha vida..

Gracias totales!!! 


\section{ÍNDICE GERAL}

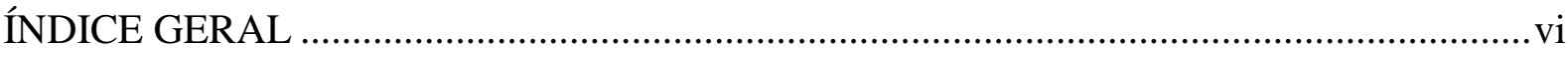

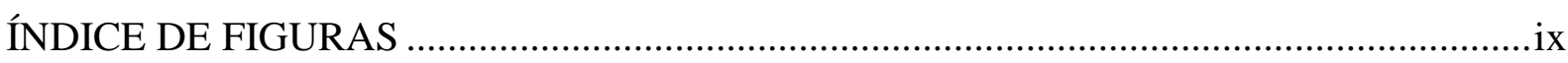

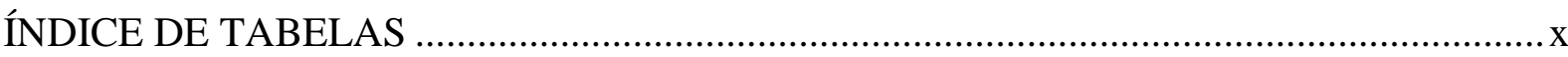

LISTA DE ABREVIATURAS E SIGLAS …..................................................................

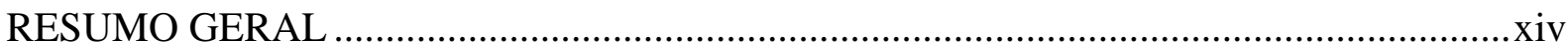

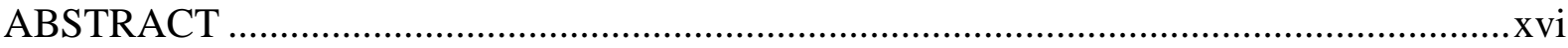

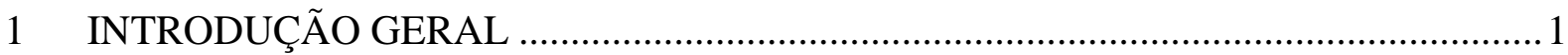

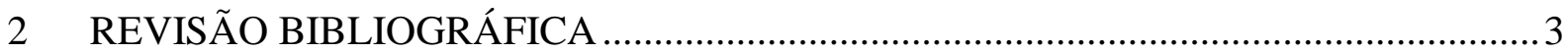

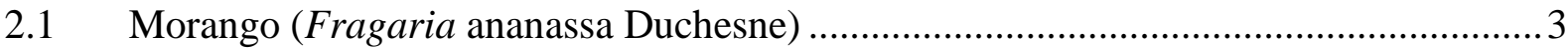

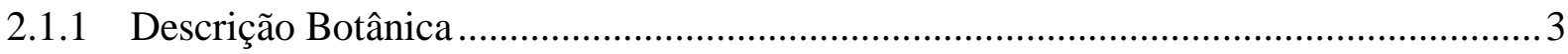

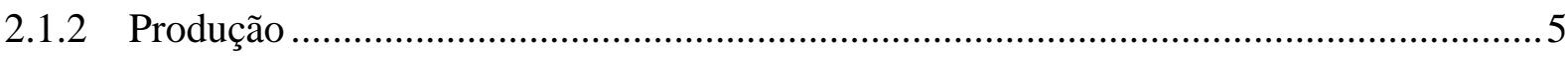

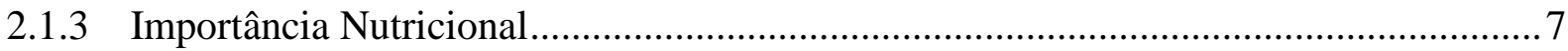

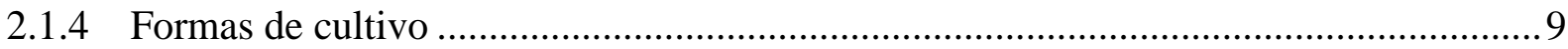

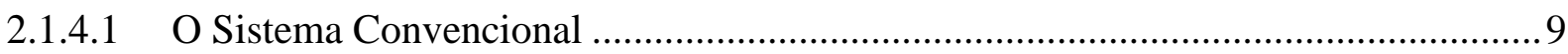

2.1.4.2 O sistema de Cultivo Orgânico................................................................................ 11

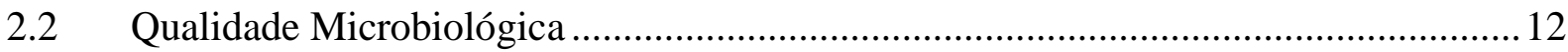

2.2.1 Microrganismos de interesse nesta pesquisa ......................................................... 13

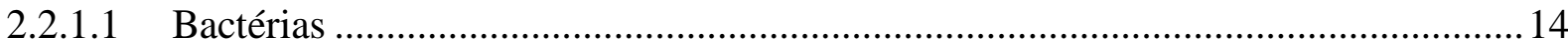

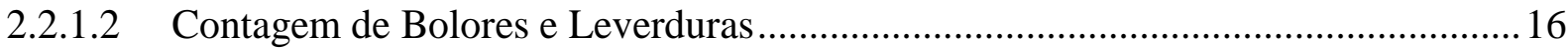

2.3 Parâmetros químicos utilizados na avaliação da qualidade de frutos...........................20

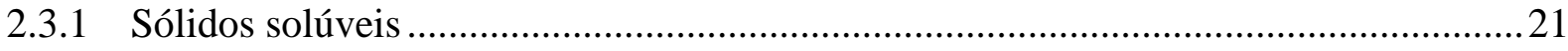

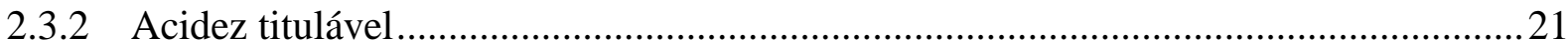

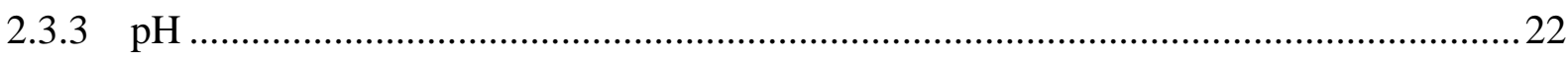

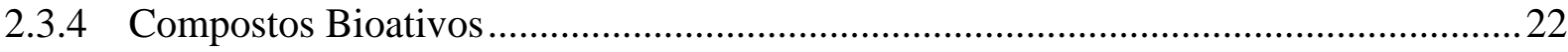

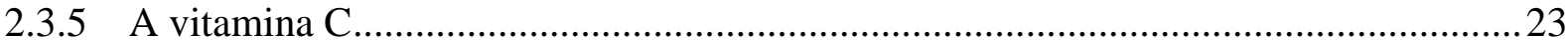

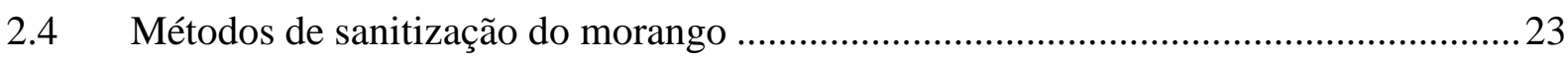

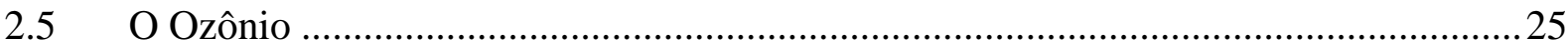

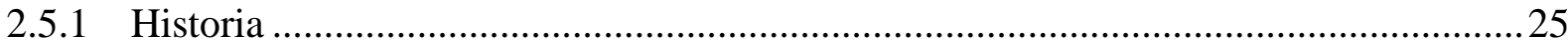

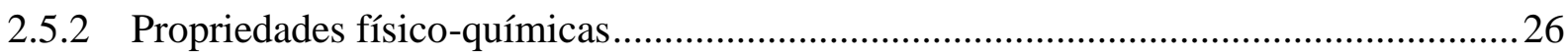




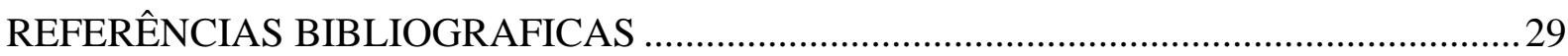

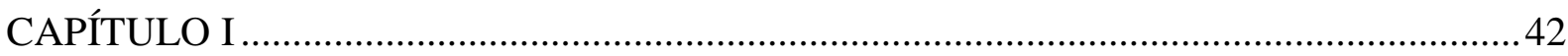

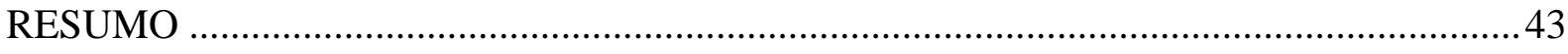

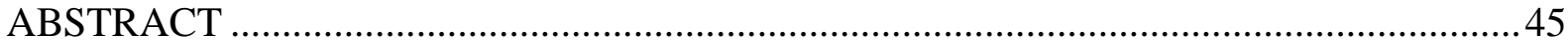

1 INTRODUÇÃ

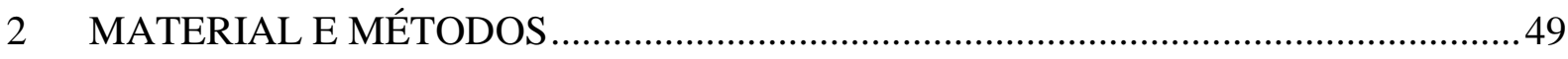

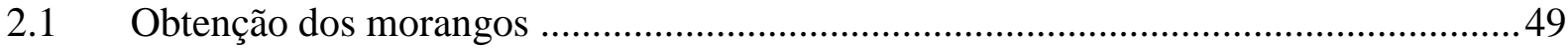

2.2 Geração do ozônio e determinação da concentração do gás ........................................49

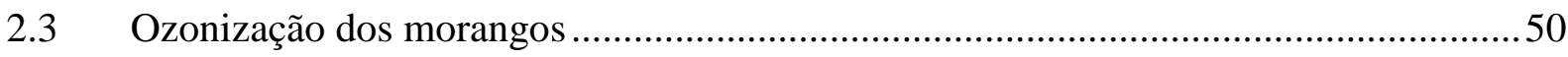

2.4 Análises microbiológicas dos morangos submetidos ou não a ozonização..................50

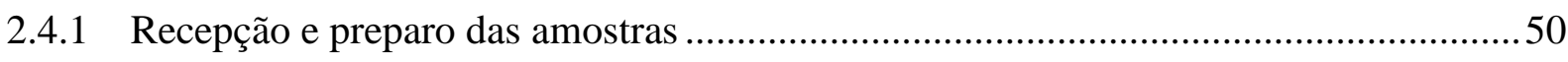

2.4.2 Preparo das diliuçoes seriadas das amostras de morango...........................................51

2.4.3 Análise de Número Mais Provável de coliformes termotolerantes e coliformes a $35^{\circ} \mathrm{C}$ 51

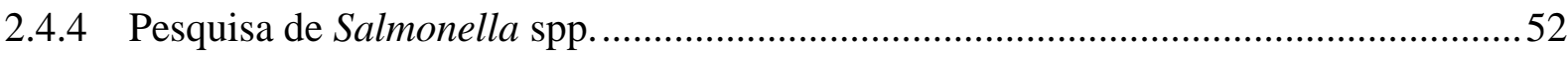

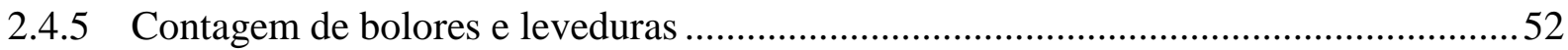

2.4.6 Contagem de bactérias Mesofílicas Aeróbias...........................................................53

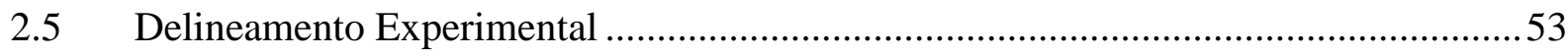

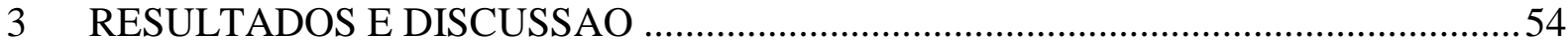

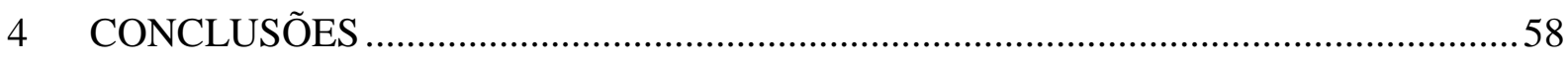

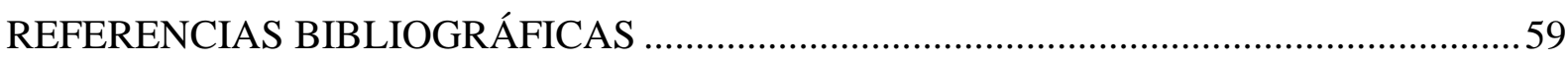

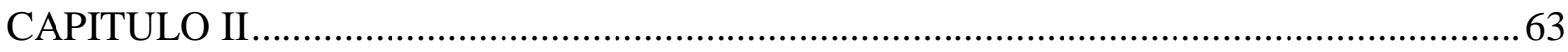

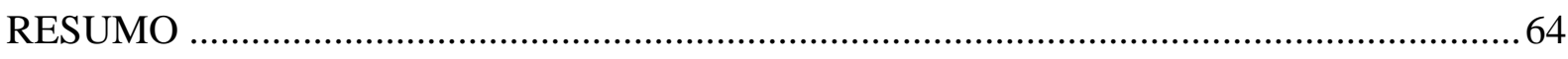

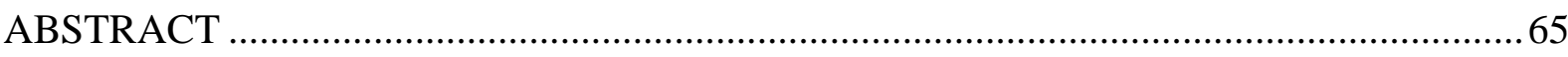

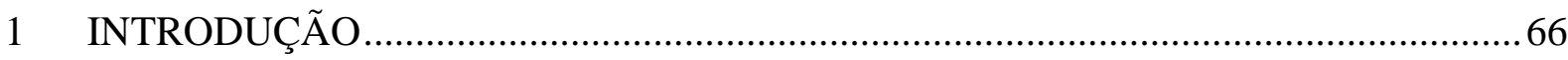

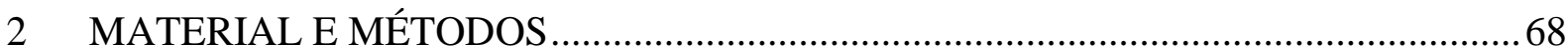

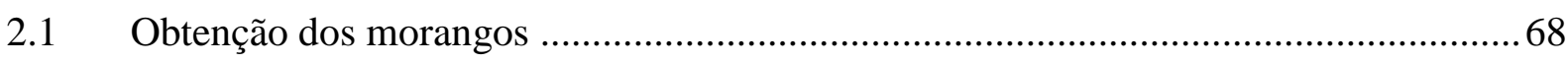

2.2 Geração do ozônio e determinação da concentração do gás ........................................68

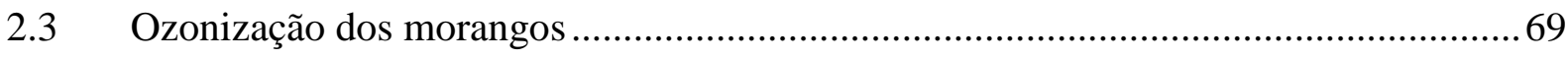

2.4 Avaliação da qualidade pós-colheita dos morangos submetidos à ozonização em

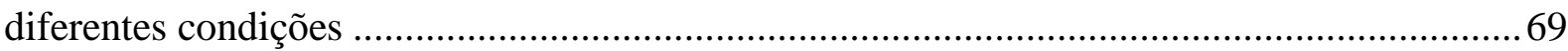

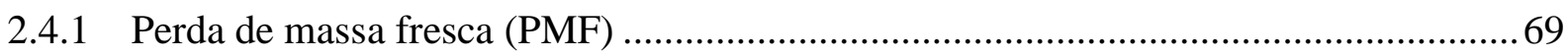




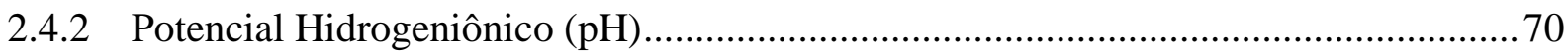

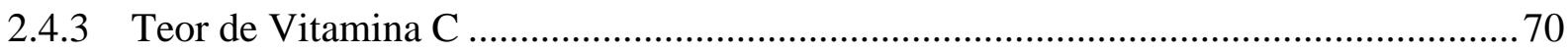

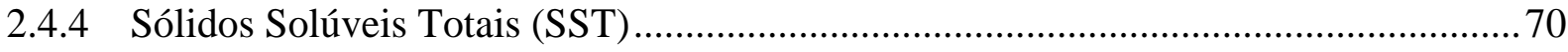

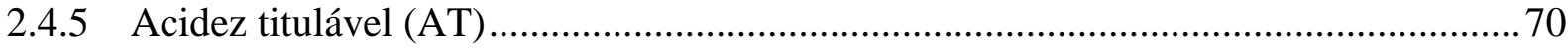

2.4.6 Relação entre Sólidos Solúveis Totais e Acidez Titulável (SST/AT) .........................70

2.4.7 Avaliação da coloração dos morangos ................................................................... 71

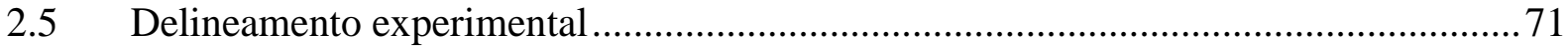

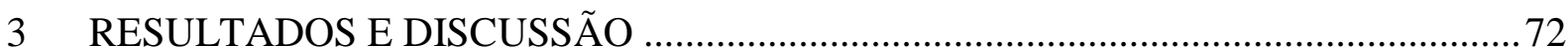

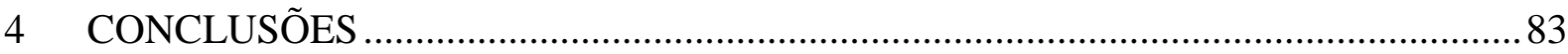

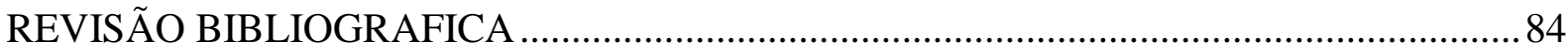




\section{ÍNDICE DE FIGURAS}

Figura 1 - Evolução da Produção mundial do morango............................................................ 6

Figura 2 - Esquema do principio de geração de ozônio baseado no método de efeito corona 28

\section{Capítulo II}

Figura 1 - Perda de massa fresca (\%) em morangos ozonizados em diferentes combinações de concentração do gás $(\mathrm{ppm})$ e período de exposição (min) e armazenados a $5{ }^{\circ} \mathrm{C}$ 71

Figura 2 - Curvas referentes ao $\mathrm{pH}$ em morangos ozonizados em diferentes combinações de concentração do gás (ppm) e período de exposição (min) e armazenados a $5{ }^{\circ} \mathrm{C}$.

Figura 3 - Teor de Vitamina C (mg 100g-1 de fruto) em morangos ozonizados em diferentes combinações de concentração do gás ( $\mathrm{ppm}$ ) e período de exposição (min) e armazenados a 5 ${ }^{\circ} \mathrm{C}$.

Figura 4- Sólidos Solúveis Totais ( ${ }^{\circ}$ Brix) em morangos ozonizados em diferentes combinações de concentração do gás (ppm) e período de exposição (min) e armazenados a 5 ${ }^{\circ} \mathrm{C}$.

Figura 5 - Saturação de cor em morangos ozonizados em diferentes combinações de concentração do gás (ppm) e período de exposição (min) e armazenados a $5{ }^{\circ} \mathrm{C}$

Figura 6 - Diferença de cor $(\Delta \mathrm{E})$ em morangos ozonizados em diferentes combinações de concentração do gás (ppm) e período de exposição (min) e armazenados a $5{ }^{\circ} \mathrm{C}$. 81 


\section{ÍNDICE DE TABELAS}

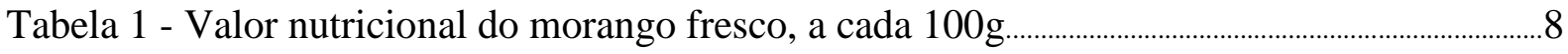

Tabela 2 - Diferentes agentes oxidantes e os respetivos potenciais de oxidação 27

\section{Capitulo I}

Tabela 1 - Contagem Total de Salmonella spp., Coliformes totais e Coliformes termotolerantes em morangos ozonizados em diferentes combinações de concentração do gás (ppm) e período de exposição (min) e armazenados a $5^{\circ} \mathrm{C}$.

Tabela 2 - Valores médios referentes contagem de bolores e leveduras (log UFC g-1) em morangos submetidos a diferentes combinações de concentração do gás (ppm) e período de exposição (min).

Tabela 3 - Valores médios referentes ao contagem de bolores e leveduras (log UFC g-1) em morangos submetidos ozonização e armazenados por 12 dias a $5^{\circ} \mathrm{C}$

Tabela 4 - Valores médios referentes à contagem de mesófilos aeróbios (log UFC g-1) em morangos ozonizados em diferentes combinações de período de exposição (min) e concentração do gás (ppm) e armazenados a $5^{\circ} \mathrm{C}$

\section{Capitulo II}

Tabela 1 - Equações de regressão ajustadas e respectivos coeficientes de determinação referentes à perda de massa fresca (\%) em morangos ozonizados em diferentes combinações de concentração do gás (ppm) e período de exposição (min) e armazenados a 5 ${ }^{\circ} \mathrm{C}$.

Tabela 2 - Equações de regressão ajustadas e respectivos coeficientes de determinação referentes ao $\mathrm{pH}$ em morangos ozonizados em diferentes combinações de concentração do gás (ppm) e período de exposição (min) e armazenados a $5^{\circ} \mathrm{C}$.

Tabela 3 - Equações de regressão ajustadas e respectivos coeficientes de determinação referentes à concentração de Vitamina C (mg 100g-1 de fruto) em morangos ozonizados em diferentes combinações de concentração do gás ( $\mathrm{ppm}$ ) e período de exposição (min) e armazenados a $5{ }^{\circ} \mathrm{C}$

Tabela 4- Equações de regressão ajustadas e respectivos coeficientes de determinação referentes a Sólidos Solúveis Totais ( ${ }^{\circ}$ Brix) em morangos ozonizados em diferentes combinações de concentração do gás (ppm) e período de exposição (min) e armazenados a 5 ${ }^{\circ} \mathrm{C}$ 
Tabela 5 - Valores médios de acidez total titulável (\% de acido cítrico) em morangos ozonizados em diferentes combinações de concentração do gás (ppm) e período de exposição (min) e armazenados a $5^{\circ} \mathrm{C}$

Tabela 6 - Valores médios de relação sólidos solúveis totais ( ${ }^{\circ}$ Brix) e acidez total titulável (\% acido cítrico) em morangos ozonizados em diferentes combinações de concentração do gás (ppm) e período de exposição (min) e armazenados a $5^{\circ} \mathrm{C}$

Tabela 7 - Valores médios de saturação de cor (Croma) em morangos ozonizados em diferentes combinações de concentração do gás ( $\mathrm{ppm}$ ) e período de exposição (min) e armazenados a $5{ }^{\circ} \mathrm{C}$

Tabela 8 - Valores médios de tonalidade de cor $\left(\mathrm{h}^{\circ}\right)$ em morangos ozonizados em diferentes combinações de concentração do gás (ppm) e período de exposição (min) e armazenados a 5 ${ }^{\circ} \mathrm{C}$.

Tabela 9 - Equações de regressão ajustadas e respectivos coeficientes de determinação referentes a diferença de cor $(\Delta \mathrm{E})$ em morangos ozonizados em diferentes combinações de período de exposição (min) e concentração do gás (ppm) e armazenados a 5 ${ }^{\circ} \mathrm{C}$ 


\section{LISTA DE ABREVIATURAS E SIGLAS}

\begin{tabular}{|c|c|}
\hline$\%$ & Porcentagem \\
\hline \pm & Mais ou menos \\
\hline${ }^{\circ} \mathrm{C}$ & Graus Celsius \\
\hline AHIA & Associação Americana de Higiene Industrial \\
\hline ANVISA & Agência Nacional de Vigilância Sanitária \\
\hline AT & Acidez titulável \\
\hline $\mathrm{CMCC}$ & California Minor Crops Council \\
\hline CSC & California Strawberry Commission \\
\hline DNA & Ácido desoxirribonucleico \\
\hline EAggEC & E.coli enteroagregativa \\
\hline $\mathrm{EC}$ & E. coli \\
\hline EFSA & European Food Safety Authority \\
\hline EHEC & E. coli. entero-hemorrágica \\
\hline EIEC & E. coli. Enteroinvasora \\
\hline EPA & Eviromental Protection Agency \\
\hline EPEC & E. coli. enteropatogênica clássica \\
\hline EPRI & Instituto de Pesquisa de Energias Elétricas \\
\hline ETA & Enfermedades transmitidas pelos alimentos \\
\hline FAO & Food and Agricultural \\
\hline FDA & Food and Drug Administration \\
\hline $\mathrm{G}$ & Grama \\
\hline GRAS & Generally Recognized as Safe \\
\hline $\mathrm{H}_{2} \mathrm{SO}_{4}$ & Ácido sulfúrico \\
\hline $\mathrm{I}_{2}$ & Iodo \\
\hline IBRAF & Instituto Brasileiro de Frutas \\
\hline ICMSF & International Commission on Microbiological Specifications for Foods \\
\hline IPD & Instituto de Promocão e Desenvolvimento \\
\hline KI & Iodeto de potássio \\
\hline LAMAL & Laboratório de Microbiologia de Alimentos \\
\hline $\mathrm{Mg}$ & Miligrama \\
\hline Mim & Minuto \\
\hline
\end{tabular}


$\mathrm{mL}$

$\mathrm{Na}_{2} \mathrm{~S}_{2} \mathrm{O}_{3}$

NPM

$\mathrm{O}_{3}$

OSHA

Ppm

SST

USDA
Mililitro

Hidróxido de sódio

Números mais provável

Ozônio

Administração de Saúde e Segurança Ocupacional

Partes por millão

Sólidos solúveis totais

US Department of Agriculture, Research Service. 


\section{RESUMO GERAL}

O morango é consumido predominantemente in-natura, sendo necessário garantir a qualidade do produto durante o cultivo, colheita, transporte e armazenamento, com intuito de reduzir perdas e alcançar melhor aceitação pelo consumidor. Dessa forma, faz-se necessária a adoção de métodos que sejam eficientes na redução de microrganismos, tanto patogênicos como deteriorantes, de tal forma a garantir a segurança do produto e, consequentemente, reduzir a velocidade do processo de deterioração. Uma alternativa que vem sendo estudada como agente antimicrobiano em produtos de origem vegetal e animal é o gás ozônio, que possui alto potencial oxidativo, o que o torna eficiente no controle dos diversos grupos de microrganismos. Diante do exposto, objetivou-se com este trabalho avaliar o efeito do ozônio aplicado em morango produzido em sistema orgânico sobre microrganismos deteriorantes e patogênicos e o efeito na qualidade do produto, adotando-se diferentes combinações de concentração e período de exposição ao gás. Foram utilizados morangos da variedade "Festival" adquiridos diretamente de um produtor orgânico da região administrativa de Brazlândia no Distrito Federal, coletados no estado de maturação comercial (3/4 maturação). Os morangos, devidamente selecionados, foram divididos em cinco lotes correspondendo aos tratamentos: morangos não ozonizados - controle; morangos ozonizados na concentração de 1000 ppm durante 30 minutos; morangos ozonizados na concentração de 1000 ppm durante 60 minutos; morangos ozonizados na concentração de 2000 ppm durante 30 minutos; morangos ozonizados na concentração de 2000 ppm durante 60 minutos. Após a ozonização, os frutos foram armazenados em câmara fria a $5{ }^{\circ} \mathrm{C}$ por 12 dias. As análises dos frutos foram realizadas no dia da ozonização (tempo zero) e a cada três dias de armazenamento. Foi avaliada a pesquisa de Salmonella spp. e a análise de Número Mais Provável de coliformes à $35^{\circ} \mathrm{C}$ e Coliformes termotolerantes, contagem de bolores e leveduras e contagem de bactérias mesofílocas aeróbias. Avaliações qualitativas dos frutos foram realizadas no dia da ozonização (tempo zero) e a cada três dias de armazenamento. As variáveis qualitativas avaliadas foram percentual de perda de massa fresca, $\mathrm{pH}$, teor de Vitamina $\mathrm{C}$, sólidos solúveis totais, acidez titulável, relação entre sólidos solúveis totais, saturação, tonalidade e diferença de cor. Adotou-se Delineamento Inteiramente Casualizado em esquema fatorial 5X5, sendo cinco tratamentos e cinco períodos de armazenamento $(0,3,6,9$ e 12 dias), com quatro repetições. Inicialmente realizou-se análise de variância e posteriormente teste de Tukey a 5\% de probabilidade. Em função da ausência de Salmonella spp. e da inexpressiva contagem de 
coliformes totais e de coliformes termotolerantes, não foi possível avaliar o efeito da ozonização sobre esses grupos de microrganismos nos morangos. Com relação à contagem de bolores e leveduras, não houve variação significativa em função da ozonização, sendo que a máxima redução foi de 0,82 ciclo $\log$, nos frutos ozonizados na concentração de 2.000 ppm, por 60 minutos. Verificou-se, no início do armazenamento, contagem de bactérias mesófilicas aeróbias nos frutos ozonizados nas concentrações de 1.000 e 2.000 ppm, por 60 minutos, foi inferior à contagem obtida nos frutos não ozonizados. Outra tendência observada foi a redução significativa na contagem de bactérias mesofílicas aeróbias no terceiro dia de armazenamento nos frutos ozonizados nas concentrações de 1.000 ppm, por 60 minutos, e 2.000 ppm, por 30 e 60 minutos, em comparação aos valores médios obtidos no início do armazenamento. O percentual de perda de massa fresca foi menos intenso nos frutos ozonizados. Em geral, as variáveis pH e sólidos solúveis totais apresentaram mesma tendência em frutos ozonizados ou não. Não houve variação significativa em função da exposição ao ozônio nas variáveis acidez titulável, relação entre sólidos solúveis totais, saturação, tonalidade de cor. Com relação a diferença de cor, ocorreu aumento menos intenso nos frutos ozonizados. Concluiu-se, a partir dos resultados obtidos, que a ozonização é um método promissor, no que tange o controle de microrganismos em morangos produzidos em sistema orgânico e na manutenção da qualidade do produto. É importante a realização de outros trabalhos, adotando-se diferentes combinações de concentração e período de exposição ao gás, de tal forma que se consiga aumentar a eficácia do método no controle dos microrganismos, sobretudo na contagem de bolores e leveduras.

Palavras-chave: Ozônio; microrganismos patogênicos; microrganismos deteriorantes; qualidade; armazenamento. 


\section{ABSTRACT}

The strawberry is predominantly consumed in-kind, being necessary to ensure product quality during cultivation, harvest, transport and storage in order to reduce losses and achieve better consumer acceptance. Thus, it is necessary to adopt methods that are effective in reducing microorganisms, both pathogenic and spoilage, so to ensure the safety of the product and thus decelerate the deterioration process. An alternative that has been studied as an antimicrobial agent in plant and animal products is ozone gas, which has high oxidative potential, which makes it effective in controlling various groups of microorganisms. Considering this, the aim of this work is to evaluate the effect of ozone applied in strawberry produced in organic system on rough and pathogenic microorganisms and also the effect on product quality, adopting different combinations of concentration and gas exposure period. It was used a variety of strawberries called Festival, acquired directly from an organic farmer in the administrative region of Brazlândia (in Distrito Federal, Brazil) collected in the state of commercial maturity (3/4 maturation). Strawberries, properly selected, were divided into five lots corresponding to the following treatments: 1) not ozonated strawberries - control; 2) strawberries ozonized at 1,000 ppm for 30 minutes; 3) strawberries ozonized at 1,000 ppm for 60 minutes; 4) strawberries ozonized at a concentration of 2,000 ppm for 30 minutes; and 5) strawberries ozonized at a concentration of 2,000 ppm for 60 minutes. After ozonation, the fruits were stored in a cold chamber at $5{ }^{\circ} \mathrm{C}$ for 12 days. The fruit analysis were performed on the day of ozonation (time zero) and each every three days storage. The presence of Salmonella spp were evaluated. Besides, and quantified total coliforms and fecal coliforms, molds and yeasts and mesophilic aerobics fruit quality evaluations were performed on the day of ozonation (time zero) and every three days of storage. Qualitative variables were percentage of weight loss, $\mathrm{pH}$, vitamin $\mathrm{C}$ content, total soluble solids, titratable acidity, soluble solids ratio, saturation, hue and color difference. Completely randomized design in factorial $5 \times 5$ was adopted, with five treatments and five storage periods $(0,3,6,9$ and 12 days), with four replications. Initially it was performed analysis of variance and subsequently Tukey test at 5\% probability. Due to the absence of Salmonella spp. and inexpressive total coliform count and coliform was not possible to assess the effect of ozonation on these groups of microorganisms in the strawberries. Considering to yeasts and molds, there was no significant variation as a function of ozonation, and the maximum reduction was $0.82 \log$ cycle, fruits ozonized at a concentration of 2,000 ppm for 60 minutes. It has been found, the beginning of storage, the mesophilic aerobic count fruit ozonized at concentrations of 1,000 
and 2,000 ppm for 60 minutes, less than the count obtained ozonized no fruit. Another trend was observed a significant reduction in the mesophilic aerobic count in the third storage day in fruit ozonized at concentrations of 1,000 ppm for 60 minutes, and 2,000 ppm for 30 and 60 minutes compared to values obtained at the start of storage. The mass loss rate was less intense in ozonated fruit. In general, $\mathrm{pH}$ and soluble solids showed the same trend ozonized fruits or not. There was no significant variation due to exposure to ozone in the variables titratable acidity, ratio of total soluble solids, saturation, color tone. Regarding the color difference has been less intense increase in ozonated fruit. It was concluded from the results obtained, that ozonation is a promising method, regarding the control of microorganisms in strawberries produced in organic system and maintaining product quality. It is important to perform multiple trials, adopting different combinations of concentration and gas exposure period, so that it can increase the effectiveness of the method in the control of microorganisms, especially yeasts and molds.

Keywords: Ozone; pathogenic microorganisms; spoilage microorganisms; quality; storage. 


\section{INTRODUÇÃO GERAL}

Alimentar-se é muito importante, mais alimentar-se bem é um dever para manter um bom estado de saúde e qualidade de vida. Atualmente existe uma grande mudança alimentar a nível mundial, o que tem provocado um aumento no consumo de frutas e hortaliças in natura. O Brasil é o terceiro maior produtor de frutas no mundo (ANUÁRIO BRASILEIRO DE FRUTICULTURA, 2014), e segundo o Instituto Brasileiro de Frutas (Ibraf), estima-se que no ano 2012 o consumo per capita de frutas atingiu os 70,84 quilos/habitante/ano.

Destaca-se dentro deste consumo as chamadas "pequenas frutas", que apresentam um grande aumento na produção. Nos últimos 60 anos o consumo mundial do morango, que forma parte desta denominação, tem apresentado um constante e elevado acréscimo, em torno de 400 vezes maior. O consumidor aprecia o morango pelos atributos intrínsecos como: a cor, o brilho, sabor, textura e odor. Além das vantagens nutricionais, antioxidantes, antiinflamatórias e antialérgicas, sendo cada vez, mas estudadas nos efeitos na saúde.

Atualmente a produção mundial segundo a FAO (2014) é aproximada a 4,52 milhões de toneladas, sendo o maior produtor os Estados Unidos, com 1.366.850 toneladas. No Brasil a produção é de aproximadamente 133.000 toneladas (EMATER, 2014). No entanto, o promissório cultivo de morango encontra-se questionado, principalmente pelo uso de químicos para o controle de pragas e doenças, o que pode provocar uma redução na qualidade do fruto ao apresentar resíduos químicos que constituem um risco para a saúde do consumidor. Em 2012, os dados publicados pela Agência Nacional de Vigilância Sanitária mostraram que foram detectados cinco diferentes tipos de resíduos de ingredientes ativos irregulares no cultivo de morango (ANVISA, 2012). Tal fato tem provocado demanda crescente por produtos com qualidade higiênico-sanitária satisfatóriao, aos consumidores optam por produtos inócuos, nutritivos e isentos de agrotóxicos.

Nesse sentido, o produtor tem procurado o aperfeiçoamento do cultivo orgânico do morango com o uso de boas práticas agrícolas de manejo, apresentando ampliação expressiva neste tipo de produção, dando um valor agregado ao morango orgânico no mercado. De acordo com Darolt (2001) apud Camargo (2008), vários produtores da região Sul do Brasil têm mostrado que o cultivo orgânico apresenta viabilidade técnica, econômica, social e ecológica.

O fruto obtido no cultivo orgânico apresenta polpa mais firme e maior quantidade de sólidos solúveis, além de apresentar coloração mais intensa (ANDRADE, 2014). Os Estados Unidos têm aumentado as vendas das pequenas frutas orgânicas em 50\% desde o ano 2008 a 
2011, e os morangos são responsáveis da metade das vendas com 37.800 toneladas colhidas. Salienta-se que o Brasil ocupa a quarta posição em superfície destinada à agricultura orgânica produtiva no mundo, com 7.114 .764 ha (IPD, 2014). E no ano 2013 o Distrito Federal apresentou uma produção de 100 toneladas aproximadamente de morango orgânico.

O morango é uma fruta muito susceptível à contaminação, e um fator limitante é garantir um eficiente manejo fitossanitário nas diferentes etapas de cultivo, pelo que são importantes estudos na fase de pós-colheita com foco em boas práticas de conservação para aumentar a vida de prateleira, e que não comprometam a pureza a microbiológica e a qualidade físico-química dos frutos.

As tecnologias de santificação são utilizadas como parte da cadeia produtiva na conservação e sanidade do produto até chegar ao consumidor. Atualmente o cloro e seus produtos derivados são os mais utilizados na higienização das verduras e frutas. A legislação brasileira tem aceitado o uso do cloro na sanitização dos alimentos, na etapa pós-colheita. No entanto, Lazarova (1999) menciona que as principais desvantagens do processo de sanitização com cloro é a formação de subprodutos químicos mutagênicos, em água e alimentos. Em virtude disso existe a necessidade de pesquisar métodos alternativos de desinfeção para uso nos alimentos.

O ozônio é considerado um método sanitizante não tradicional. Foi descoberto em 1785, e usado pela primeira vez no ano 1906 na França, numa estação de tratamento de água potável. No ano de 1982, a GRAS (Generally Recognized as Safe), aprovou seu uso para sanitização de alimentos e em 1995, os Estados Unidos fez uso do ozônio para a sanitização de garrafas de água (GRAHAM, 1997; SOPHER et al., 2002; GUZEL-SEDYDIM, 2004). Além disso, o ozônio tem sido proposto como alternativa no controle de insetos de grãos armazenados (ROZADO et al., 2008). Nos Estados Unidos o uso de ozônio foi aprovado no Food Drug Administration (FDA) a partir de 26 de Junho de 2001 (FDA, 2001).

Existem diferentes trabalhos referentes ao uso de ozônio como sanitizante de alimentos, no entanto, são necessários estudos mais aprimorados desta tecnologia para estabelecer a eficiência das doses ou tempos de exposição do gás, para assim garantir a pureza microbiológica e não comprometer as características físico-químicas dos alimentos.

Em vista ao exposto, o objetivo deste trabalho foi avaliar a ozonização como método alternativo na conservação de morango produzido em sistema orgânico, adotando-se diferentes condições. 


\section{REVISÃO BIBLIOGRÁFICA}

\subsection{Morango (Fragaria ananassa Duchesne)}

\subsubsection{Descrição Botânica}

O morango pertence ao Reino Plantae, divisão Magnolophyta, classe Magnoliopsida, ordem Rosales, família Rosaceae, subfamília Rosoideae, tribo Potentilleae, e gênero Fragaria (SILVA et al., 2007). Existem aproximadamente 24 espécies destas, 12 são diploides $(2 n=2 x=14)$, cinco tetraploides $(2 n=4 x=28)$, um hexaploide $(2 n=6 x=42), 2$ octaploides $(2 \mathrm{n}=8 \mathrm{x}=56)$, um decaploide $(2 \mathrm{n}=10 \mathrm{x}=70)$ e três espécies hibridas $F$ x bifera (diploide e triploide), F. x bringhurstii (pentaploide, hexaploide e nanoploide) e $F \times$ ananassa ssp. cuneifolia (HUMMER et al., 2009; STAUDT, 2009).

No inicio do século XVIII, um oficial do exército francês, Amédee Frézier, levou algumas plantas da espécie Fragaria chiloensis L. Duchesne originária do sul do Chile e da Argentina para o jardim do Rei em Paris, onde clones da espécie Fragaria virginiana Duchesne, originária do leste de América do norte, encontravam-se em cultivo. Os híbridos que emergiram de um cruzamento acidental entre estas duas espécies apresentaram boas características em tamanho, cor e odor o que provocou um grande desenvolvimento da indústria de morango na França sendo o primeiro híbrido nomeado como Fragaria ananassa Duchesne nomeado também "pinheiro" ou "morango abacaxi” (DARROW, 1966). O morango pinheiro tornou-se o progenitor do morango que é cultivado até hoje, sendo a espécie mais cultivada e mais importante economicamente (STAUDT, 1962; TOLEDO, 2003; NYUGUNA, 2010).

Existem relatos sobre a ocorrência das espécies Fragaria vesca e Fragaria moschata, na França e na Inglaterra, desde o século XV (SANHUENZA, 2005; OLIVEIRA 2012). Na atualidade, são conhecidos cultivares que possuem genes de Fragaria vesca e Fragaria ovalis, de origem européia (BRAHM et al., 2004).

O morangueiro é uma planta perene, dicotiledônea, herbácea e estolonífera. Apresenta caule semisubterrâneo, curto e fibroso, chamado coroa, com entrenós curtos, cujas gemas terminais permitem o desenvolvimento das folhas. As folhas são alternas compostas, trifoliadas e inseridas no caule por pecíolos considerados longos. Os folíolos são dentados de 
cor verde escuro na face superior acinzentada e pilosa na inferior e apresentam crescimento rasteiro (GUIMARÃES et al., 2013).

O sistema radicular é fasciculado, compreendendo raízes primárias e secundárias. Esta ultima é constantemente renovada a cada vez que morrem e atingem uma profundidade normalmente de 50 a $60 \mathrm{~cm}$ das quais, aproximadamente nos $95 \%$ se fixam nos primeiros 20 cm de solo (RONQUE, 1999). As raízes apresentam um sistema fasciculado e originam-se da coroa e crescem principalmente nas épocas de dias curtos, menor do que 12 horas de luz. Em épocas frias é necessário utilizar cobertura plástica para elevar a temperatura do solo, favorecer o crescimento radicular, ajudar no controle de doenças (SANHUENZA et al., 2005). Os estolões se desenvolvem das gemas basais, capazes de gerar raízes dando origem a novas plantas.

Suas flores são geralmente hipogínicas e andrógenas, porém, em algumas cultivares, as flores podem ser unissexuais masculinas ou femininas (BRANZANTI, 1989; RONQUE, 1998 apud CAMARGO, 2008). Encontram-se agrupadas em inflorescências e o número varia muito numa mesma cultivar e estas inflorescências apresentam um pedúnculo floral que é ereto e curva-se após a polinização na formação do fruto. As pétalas são livres e lobuladas, podendo ser brancas ou avermelhadas, dispostas ao redor do receptáculo apresentando de oito a dez sépalas. Após a fecundação, os óvulos se transformam em aquênios que estimulam o engrossamento do receptáculo, convertendo-se numa superfície comestível que é botanicamente denominado como pseudofruto ou infrutescência, o que chamamos de morango. Os aquênios permanecem aderidos a esta superfície sendo os frutos verdadeiros, diminutos que apresentam cores vermelhas ou amarelas, sendo composto por uma única semente (HENNION et al.,1997; SANHUENZA et al., 2005).

$\mathrm{Na}$ atualidade, em função dos trabalhos desenvolvidos de melhoramento genético, existe muitas cultivares adaptados às diferentes condições climáticas e ambientais. No Brasil, a cultura foi distribuída em diversas regiões no início da década de 1970. Nesta mesma época no Rio Grande do Sul houve grande impulso comercial do morango, concentrando-se principalmente no Vale do Rio Caí e na Serra Gaúcha e a cultivar Campinas foi uma das primeiras cultivares utilizadas (SANHUENZA et al, 2005; PASSOS, 1998). Além disso, surgiram as cultivares Guarani, Monte Alegre e Princesa Isabel desenvolvidos pelo Instituto Agronômico de Campinas. As cultivares Santa Clara, Konvoy-Cascata e Vilanova foram concebidos pela Embrapa Clima Temperado (ANTUNES; FILHO, 2005). 
A cultivar Flórida Festival utilizada neste trabalho, é originaria do cruzamento entre a cultivar Rosa linda da Estação de Agricultura da Flórida e a cultivar Oso grande da Universidade da Califórnia. As quais foram selecionadas por apresentar características como: maior rendimento no inicio da produção, bom formato do fruto, maior tamanho e firmeza dos frutos em relação ás cultivares produzidas na época de seu desenvolvimento. Esta cultivar tem sido desenvolvida desde 1995, e os últimos ensaios foram realizados em Janeiro do ano 2000 na Universidade de Flórida. Esta cultivar é suscetível à antracnose causada por Colletotrichum acutatum Simmonds e podridão da coroa causada por Colletotrichum gloeosporodies Penz. No Brasil esta cultivar foi introduzido pela primeira vez no ano 2007 do país Argentino (CHANDLER et al., 2000).

A cultivar Flórida Festival é de dias curtos, isto é, iniciam o florescimento em condições de fotoperíodo geralmente menor do que 12 horas. Em épocas de outono e inverno, apresenta aparência vigorosa e os folíolos apresentam comprimentos de 7 a $12 \mathrm{~cm}$, com cálices grandes e vistosos e frutos de forma cônica. Quando maduros, os frutos apresentam aspecto brilhante e coloração vermelha escura, com textura firme e excelente odor. Esta cultivar é suscetível a Antracnose causada por Colletotrichum acutatum Simmonds e a mancha-angular, ocasionada por Xanthomonas fragariae Kennedy \& King (CHANDLER, 2000).

\subsubsection{Produção}

Na última década, o cultivo e a produção do morango têm aumentado de acordo com a demanda de mercado. Os maiores produtores em 2013 foram os Estados Unidos, com 1.366.850 toneladas do fruto, seguido pelo México com 360.426 toneladas, Turquia 353.173 toneladas, Espanha 289.900 toneladas, e Egito 242.297 toneladas (FAO, 2014). A produção mundial do morango dos últimos 60 anos (Figura 1), aumentou constantemente, sendo um cultivo difundido em todo o mundo. 


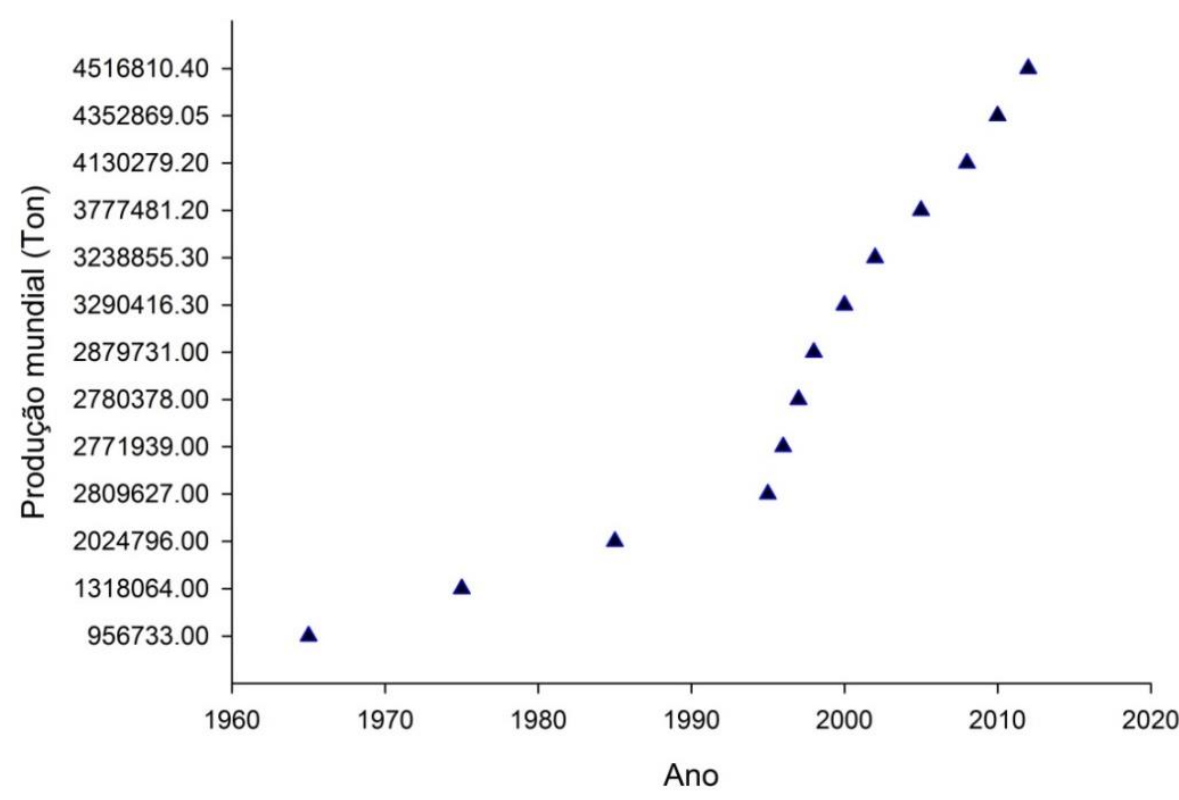

Figura 1 - Evolução da Produção mundial do morango. Fonte: FAOSTAT (2014).

No Brasil, a produção total do morango alcança 133 mil toneladas, ocupando 3.718 hectares. A maior parte da produção no país distribui-se entre cinco estados. Minas Gerais aparece como o maior produtor do país, com 72 mil toneladas em 1.790 hectares, responsável por quase 55\% da produção nacional. Essa atividade gera aproximadamente 26 mil empregos e envolve 5.900 produtores na atividade (EMATER - MG 2012). Em segundo lugar esta São Paulo, com 31.000 toneladas, seguido pelo Rio Grande do Sul, com 16.000 toneladas, Paraná com 9.000 toneladas e Espírito Santo com 7.000 toneladas (FERNANDES, 2013).

No Distrito Federal, o cultivo do morango foi introduzido no ano 1960 de maneira experimental por agricultores de origem japonesa vindos da região de Atibaia em São Paulo. Segundo a EMATER no ano 2013 o DF destacou-se como pilar econômico na produção do morango com 6.632 toneladas, vindas de 182 produtores, o que representa, a nível familiar, uma elevada demanda de mão de obra, permitindo a geração de emprego e renda local. Do total atual da produção, 97,7\% deste cultivo ocorre no sistema convencional, e 1,48\% é cultivado no sistema orgânico (sendo um total de 98,5 toneladas). O sistema agroecológico corresponde com uma pequena porcentagem, 0,87\% (LOPES et al., 2005; HENZ, 2010; ANTUNES, 2013). 


\subsubsection{Importância Nutricional}

O morango é considerado atraente pelas características sensoriais e, principalmente pela composição nutricional. Os morangos contêm fibras, carboidratos, proteínas e açúcares. Possuem também os principais minerais, vitaminas do complexo $\mathrm{B}$, ácido fólico e vitamina $\mathrm{C}$, além de ser uma rica fonte de compostos fitoquímicos, representados pelos polifenóides que, em conjunto, atuam como agentes antioxidantes (GIAMPIERI et al., 2012). Segundo estudos realizados, tem-se demonstrado que os morangos apresentam de 2 a 11 vezes maior capacidade antioxidante do que as maçãs, pêssegos, peras, uvas, tomates, laranjas e kiwis (WANG; CAO, 1996; HALVORSEN et al., 2002; SKALZO et al., 2005).

Existem evidências de que, em função do amplo conteúdo de fibra dietética e frutose, estes frutos podem contribuir na regulação dos níveis de açúcar. Sendo uma importante fonte de ácidos graxos, essenciais à saúde, encontrados nas sementes deste (USDA, 2010).

O morango apresenta alto teor de ácido ascórbico, vitamina importante para a nutrição humana (SKALZO et al., 2005). A vitamina C destaca-se pela ação antiescorbútica. A deficiência desta vitamina pode provocar lesões na mucosa intestinal, hemorragias digestivas, vermelhidão nas gengivas, enfraquecimento dos dentes, dores agudas e inchaço nos membros superiores e inferiores além de deficiência no processo de cicatrização (BASU; SCHORAH, 1982). Para o ser humano é impossível sintetizar este tipo de vitamina sendo essencial adicionar na dieta alimentar o consumo de frutas e vegetais ricos em vitamina C. A ingestão diária recomendada de ácido ascórbico é de 100-150 mg / dia em adultos, que podem ser atendidas com uma média de $100 \mathrm{~g}$ de morangos por dia (ROSA et al., 2007).

São fontes naturais de compostos Polifenóides, que estão presentes na maioria das frutas com uma estrutura básica $\mathrm{C}_{6}-\mathrm{C}_{3}-\mathrm{C} 6$ da cadeia carbônica (ZHAO, 2007). A principal classe destes compostos é representada pelos flavonoides, sobretudo as antocianinas e antocianidinas que apresentam efeitos positivos na saúde, combatendo os radicais livres gerados pelo metabolismo celular e produzindo antioxidantes que protegem o coração, auxiliando na cicatrização, resistência capilar e melhorando o funcionamento da memória, por evitarem a oxidação das células, ajudando na absorção de ferro e na resistência aos processos infecciosos (SANHUENZA et al., 2005; FREEMAN, 2011; PINELLI, 2009). 
Tabela 1 - Valor nutricional do morango fresco, a cada 100g

\begin{tabular}{|c|c|c|}
\hline \multicolumn{3}{|c|}{ Tipo de Nutrientes por $100 \mathrm{~g}$} \\
\hline \multirow{11}{*}{$\begin{array}{c}\text { Principais } \\
\text { Componentes }\end{array}$} & Água (g) & 90,95 \\
\hline & Energia (kcal) & 32 \\
\hline & Proteína $(\mathrm{g})$ & 0,67 \\
\hline & Cinzas (g) & 0,4 \\
\hline & Totais lipídios (g) & 0,3 \\
\hline & Carboidratos (g) & 7,68 \\
\hline & Fibra alimentar (g) & 2 \\
\hline & Açúcares (g) & 4,89 \\
\hline & Sacarose $(\mathrm{g})$ & 0,47 \\
\hline & Glucose (g) & 1,99 \\
\hline & Frutose $(\mathrm{g})$ & 2,44 \\
\hline \multirow{10}{*}{ Minerais } & Cálcio (mg) & 16 \\
\hline & Ferro (mg) & 0,41 \\
\hline & Magnésio (mg) & 13 \\
\hline & Fósforo (mg) & 24 \\
\hline & Potássio (mg) & 153 \\
\hline & Sódio (mg) & 1 \\
\hline & Zinco (mg) & 0,14 \\
\hline & Cobre (mg) & 0,048 \\
\hline & Manganês (mg) & 0,386 \\
\hline & Selênio (mg) & 0,4 \\
\hline \multirow{17}{*}{ Vitaminas } & Vitamina C (mg) & 58,8 \\
\hline & Tiamina (mg) & 0,024 \\
\hline & Riboflavina (mg) & 0,022 \\
\hline & Niacina (mg) & 0,386 \\
\hline & Ácido pantotênico (mg) & 0,125 \\
\hline & Vitamina B6 (mg) & 0,047 \\
\hline & Folato (mg) & 24 \\
\hline & Colina (mg) & 5,7 \\
\hline & Betaína (mg) & 0,2 \\
\hline & Vitamina B12 (mg) & 0 \\
\hline & Vitamina A, RAE (mg) & 1 \\
\hline & Luteína p zeaxantina (mg) & 26 \\
\hline & Vitamina E, a-tocoferol (mg) & 0,29 \\
\hline & b-tocoferol (mg) & 0,01 \\
\hline & g-tocoferol (mg) & 0,08 \\
\hline & d-tocoferol (mg) & 0,01 \\
\hline & Vitamina $\mathrm{K}$, filloquinona (mg) & 2,2 \\
\hline
\end{tabular}

Fonte: Adapted from the U.S. Department of Agriculture, Agriculture Research Service.

(GAMPIERI et al., 2012). 


\subsubsection{Formas de cultivo}

Atividades agrícolas têm sido desenvolvidas pelo homem há 10.000 anos, e aperfeiçoadas segundo a necessidade a preferência alimentar e sobre tudo devido ao crescimento populacional. Essas mudanças provocaram o uso de diferentes técnicas de produção, maquinarias, adubos sintéticos, variedades melhoradas geneticamente e a intensificação do uso de agrotóxicos desenvolvidos, originando um grande desequilíbrio ecológico e o prejuízo ao meio ambiente e à saúde humana (tanto para o consumidor quanto para o produtor). Em virtude disto, entre as décadas de 1980 e 1990, surgiram na Europa, as primeiras medidas de controle do uso indevido de agrotóxicos, da busca da preservação do ambiente e do aproveitamento dos recursos no cultivo (MAZOYER; ROURDAT 2008, MARQUES et al., 2004; ILBERY, 1998).

A partir de 1984, o Ministério da Agricultura dos Estados Unidos da América tem reconhecido o uso de sistemas orgânicos como uma solução para os problemas ambientais decorrentes de uma agricultura produtivista intensiva no país. Na conferência das Nações Unidas RIO-92, reconheceu-se a necessidade de adotar práticas na agricultura para o desenvolvimento sustentável das nações, paralela a esta conferência no Fórum Global 92, organizações não governamentais (ONGs), juntamente com a sociedade civil iniciaram o Tratado das ONGs, referente à agricultura sustentável. Para isto a Organización Internacional de Normalización (ISSO) ajudou na regulamentação do comércio interno e na exportação, operacionalizando a maioria dos acordos firmados na RIO-92 (NEVES et al., 2000).

Vive-se, atualmente, num período emergente. De um lado a agricultura convencional, responsável pela grande produção de commodities, mas por outro, diferentes tendências de agricultura, como a agricultura orgânica, que tem ganhado muito espaço na preferência do consumidor, que anseia obter produtos sadios, livres de agrotóxicos e pela preocupação com a conservação do meio ambiente (HESPANHOL; BARBOSA, 2011).

\subsubsection{O Sistema Convencional}

O sistema convencional foi impulsionado nas décadas de 60 e 70, denominado como a Revolução Verde e que foi utilizado em grande parte dos cultivos. A agricultura convencional é o modo agrícola no qual prevalece a busca de maior produtividade, por meio da utilização 
intensa de insumos externos, que em curto prazo traz resultados econômicos visíveis, como o aumento da produtividade e a eficiência agrícola (MAZOYER; ROURDAT, 2008).

No cultivo convencional, o uso de produtos químicos contra pragas e doenças é prática fundamental. No Brasil, a Lei, conhecida como Lei de Agrotóxicos, regulamentada pelo Decreto de Lei $\mathrm{n}^{\circ} 4.074$ de 4 de Janeiro de 2002, adota e define o termo agrotóxico para ser empregado em substituição a termos como: defensivos agrícolas, biocidas, pesticidas, praguicidas, produtos fitossanitários e agrotóxicos. A Agência de Proteção Ambiental (EPA) define o termo agrotóxico como uma substância química ou mistura de substâncias utilizadas para prevenir, destruir, repelir ou mitigar qualquer praga, ou mesmo, para regular, desfolhar e dessecar plantas (EPA, 2014; JARDIM, 2009)

No Brasil, a maior parte da produção de morango é obtida pelo cultivo convencional. Segundo a EMATER, no ano de 2013, o Distrito Federal teve uma produção de 6.480 toneladas de morango convencional, o que representa $97 \%$ da produção total na região (ANTUNES, 2013). No cultivo do morango, o sistema convencional baseia-se principalmente no uso de agroquímicos para conter o aparecimento de pragas e doenças, o que pode provocar a redução da qualidade do fruto, por apresentar resíduos químicos que constituem risco para a saúde do consumidor.

No ano 2012, dados publicados pela Agência Nacional de Vigilância Sanitária evidenciou a presença de cinco diferentes tipos de resíduos de ingredientes ativos irregulares (ANVISA, 2012). Por meio do Programa de Análise de Resíduos de Agrotóxicos em Alimentos (PARA), baseados nos relatórios de atividades divulgados no ano 2012, o morango juntamente com o pimentão e o pepino, lidera o ranking dos alimentos mais contaminados, com presença de resíduos de agrotóxicos, totalizando 59\% de amostras irregulares. Dentre os problemas detectados nas análises dessas amostras, encontram-se teores de resíduos de agrotóxicos acima do limite máximo de resíduos (LMR) permitido. Além, do uso de agrotóxicos não autorizados para esta cultura. As amostras utilizadas nas análises foram tomadas de 12 estados do país. Tal fato tem ocorrido desde o ano 2002 com a cultura do morango, revelando os resultados insatisfatórios mais elevados nas análises de resíduos de agrotóxicos na categoria de frutas (OSHITA, 2012). 


\subsubsection{O sistema de Cultivo Orgânico}

No ano 2008 o Brasil permaneceu entre os cinco primeiros países com destaque em termos de área de cultivo orgânico no mundo, com 1.770 .000 hectares, e a produção continua crescendo a uma taxa de $20 \%$ ao ano (MADAIL et al., 2007; EMBRAPA, 2010). Atualmente, a demanda do mercado orgânico é cada vez mais exigente e aumenta o número de consumidores que optam por produtos livres de agrotóxicos, que não causem danos à saúde e que não representem risco ao meio ambiente (GAZZONI, 2006).

De acordo com a Lei ${ }^{\circ} 10.831$ de 2003 , consideram que:

\footnotetext{
"Sistema orgânico de produção agropecuária todo sistema em que se adotam técnicas específicas, mediante a otimização do uso dos recursos naturais e socioeconômicos disponíveis e o respeito à integridade cultural das comunidades rurais, tendo por objetivo a sustentabilidade econômica e ecológica, a maximização dos benefícios sociais e a minimização da dependência de energia não renovável, empregando, sempre que fora possíveis métodos culturais, biológicos e mecânicos, em contraposição ao uso de materiais sintéticos, a eliminação do uso de organismos geneticamente modificados e radiações ionizantes, em qualquer fase do processo de produção, processamento, armazenamento, distribuição e comercialização, e a proteção do meio ambiente".
}

Abrangendo nesta legislação, todas as diferentes correntes de agricultura alternativa ou sustentável ou ecológica como Agricultura Biodinâmica, Agricultura Orgânica, Agricultura Organobiológica e Agricultura Natural (SCHULTZ, 2007).

Alguns pioneiros da produção agroecológica do Brasil definem a Agricultura Orgânica como um sistema de produção que evita o uso de fertilizantes sintéticos, agrotóxicos, reguladores de crescimento e aditivos para a alimentação animal obtido sinteticamente. Os sistemas de agricultura orgânica baseiam-se na rotação de culturas, elaboração de adubos aproveitando o esterco animal, leguminosas, resíduos orgânicos e minerais naturais. São aspectos importantes deste sistema, o controle biológico de pragas para manter a estrutura e produtividade do solo e o fornecimento de nutrientes para as plantas (DULEY, 2003). Visando estabelecer sistemas agrícolas ecologicamente equilibrados e produtivos, independentemente se pequenos ou grandes produtores, o objetivo é obter alimentos nutritivos e livres de resíduos tóxicos (MADAIL et al., 2007). 
Os Estados Unidos é o maior produtor de morango, mas o cultivo orgânico representa $3 \%$ do total da produção, com uma área plantada de 663 hectares e 20.198,55 toneladas de produção, sendo os estados da Califórnia e Washington, os maiores produtores (PEREZ; PLATTNER, 2013). No Brasil, a produção total do morango está crescendo e contabiliza cerca de 133 mil toneladas por ano com área ocupada de 3.500 ha, estima-se que, apenas $1 \%$ desse total, seja cultivado no sistema orgânico (ANTUNES et al., 2007). A produção Integrada do Morango (PIMo) surgiu no ano 2008 como uma necessidade em função da conscientização dos produtores de se adaptarem aos novos princípios e a se qualificarem, a fim de poderem competir no mercado internacional (ANDRIGUETO et al., 2008; MANDAIL et al., 2007). No Distrito Federal, no ano 2013, o cultivo orgânico de morango alcançou uma produção de 98,5 toneladas, representando 1,5\% do total da produção agrícola, segundo a pesquisa desenvolvida pela EMATER - DF (ANTUNES, 2013).

\subsection{Qualidade Microbiológica}

O consumo in natura de morango orgânico está comprometido pela suscetibilidade dos frutos à contaminação microbiológica. As más práticas de manejo do cultivo, manipulação dos frutos sem um devido controle, o uso de matéria orgânica sem os devidos processos de compostagem entre outros, tem permitido que os patógenos penetrassem na epiderme dos frutos do morango, e o consumo deste, causa afecções à saúde humana (BOLLEN, 1985; OSHITA, 2012). Outra forma de contaminação é o uso de água de irrigação contaminada, fator que favorece ao desenvolvimento de potentes microrganismos contaminantes (VANETTI, 2007). O contexto pode se tornar pior se a manipulação na colheita e antes da comercialização não é precedida de algum processo de lavagem, sanitização e refrigeração (MATTOS, 2004). Para garantir morangos de boa qualidade é fundamental que os indivíduos envolvidos nesta atividade adotem boas práticas agrícolas e de produção, evitando o número de enfermidades transmitidas pelos alimentos (ETA) (ALCÂNTARA, 2009).

Existem fatores que determinam a capacidade de sobrevivência ou multiplicação dos microrganismos e se relacionam com as características intrínsecas do alimento como: a água, o pH, o potencial de oxi-redução, a composição química, os fatores antimicrobianos naturais e a interação entre micro-organismos. Os fatores externos, também chamados "extrínsecos" 
são a temperatura ambiental, umidade relativa do ambiente e composição gasosa do ambiente (FRANCO; LANDGRAF, 2008).

Os microrganismos presentes nos alimentos podem ser classificados de acordo com o tipo de interação existente:

- Microrganismos deteriorantes: produzem alterações químicas prejudiciais causando deterioração microbiana e modificação das características organolépticas. Estas modificações ocorrem pela atividade metabólica dos micro-organismos que tentam perpetuar a espécie usando os alimentos como fonte de energia, nitrogênio, água e vitaminas;

- Microrganismos patogênicos: são um risco para a saúde humana ou animal e podem afetar aos homens e animais o que vai depender do tipo de alimento consumido e o micro-organismo presente. Geralmente a presença deste patógeno é um indicador de condições insatisfatórias de sanidade nas diferentes etapas agrícolas.

- Microrganismos que junto aos alimentos produzem alterações benéficas transformando as características e obtendo como resultado um novo alimento. Estes tipos de microrganismos são encontrados há muito tempo na fabricação de vinho, cerveja, queijo, etc. (FRANCO; LANDGRAF, 2008)

\subsubsection{Microrganismos de interesse nesta pesquisa}

Considerando um panorama onde o morango e a sua susceptibilidade ao manejo, a composição nutricional (água, energia, proteína e açucares) e as condições ambientais inadequadas para a conservação tem o perfeito ambiente para o desenvolvimento de microorganismos deteriorantes e patogenicos. Segundo o ICMSF (1998), a microbiota normalmente presente no fruto do morango constitui-se em bolores, leveduras, bactérias lácticas e outros micro-organismos, ácido tolerantes como bactérias acéticas, Zynomonas e algumas espécies de Bacillus. Isso ocorre quando o pH nos frutos diminui. As bactérias estão normalmente presentes em número reduzido encontrados em vegetais e frutas que incluem pseudômonas, coliformes e mesofilos (SANTOS, 2008). 


\subsubsection{Bactérias}

Os coliformes formam parte dos micro-organismos indicadores utilizados na avaliação da qualidade microbiológica dos alimentos. No ano 1914, institutos americanos de saúde pública atribuíram a estes micro-organismos a função de grupo padrão de significância sanitária. No Brasil, o Ministério da Saúde, a partir da resolução $\mathrm{n}^{\circ} 12$, de 2 de janeiro de 2001, da Agência Nacional de Vigilância Sanitária (ANVISA) adotou a denominação de coliformes a $45^{\circ} \mathrm{C}$, sendo que este tomaram os padrões de origem fecal e termotolerantes. Além, se serem conhecidos como micro-organismos indicadores, existem cepas patogênicas que produzem sérias doenças no homem e os animais (FRANCO; LANDGRAF, 2008).

Os coliformes totais são bactérias da família Enterobacteriaceae que apresentam formas de bastonetes, gram-negativas, não produzem esporos e podem ser aeróbios ou anaeróbios facultativos, no processo de fermentação da lactose gerando um gás, a $37^{\circ} \mathrm{C}$ a partir de 24 a 48 horas. Pertencem a este grupo as bactérias dos gêneros Escherichia, Enterobacter, Citrobacter e Klebsiella, dos quais só Escherichia coli tem como hábitat primário o trato intestinal e os outros gêneros estão presentes no ar, na poeira, no solo e em diferentes alimentos. É importante avaliar a presença destes micro-organismos e conhecer as condições higiênicas, já que elevadas contagens destes organismos indicam contaminação dos alimentos, nos diferentes processos de produção (SIQUEIRA et al., 1997).

Os coliformes termotolerantes diferenciam-se dos coliformes totais pela capacidade de multiplicar-se e fermentar a lactose a $44,5^{\circ} \mathrm{C}$, em 24 horas e produzir gás. Incluem algumas cepas de Enterobacter e Kliebsiella, sendo as mais importantes as do gênero Escherichia, que indica contaminação fecal. O meio de vida primária da Escherichia coli é o trato intestinal (de animais e do homem) encontrado também no solo e em adubos elaborados com estercos o que torna a contaminação muito fácil. Sobrevive em estercos de animais durante 56 dias a $37{ }^{\circ} \mathrm{C}$ (SIQUEIRA, 1997; SILVA et al., 2007).

Escherichia coli representa bactérias gram-negativas não esporuladas que apresentam forma de bastonetes. É considerada a espécie dominante estando entre os micro-organismos anaeróbios facultativos que comumente fermentam lactose com produção de ácido e gás, conseguindo fermentar glicose, que produz igualmente ácido e gás. Fazem parte da microbiota intestinal dos humanos e animais de sangue quente, estirpes não patogênicas. Entretanto, algumas estirpes são patogênicas e apresentam fatores de virulência, provocando 
no homem, infecções gastrointestinais, tais como diarreia, cólicas intestinais e hemorrágicas e infecções como síndrome hemolítico-urêmica, além de meningites e septicemias (OFFIT; MOSER, 2009; DUBREIL, 2014; YANG; WANG, 2014).

Segundo Franco; Landgraf (2008), as estirpes patogênicas de E.coli dividem-se em cinco categorias segundo características como virulência, evidências clínicas e epidemiologia: E. coli. enteropatogênica clássica (EPEC); E. coli. enteroinvasora (EIEC); E. coli. enterotoxigênica (ETEC); E. coli. entero-hemorrágica (EHEC) e E.coli enteroagregativa (EAggEC). No ano 2011, os EUA tiveram surtos de origem alimentar relacionados ao sorotipo E. coli O157: H7, pertencente às cepas de EHEC em morangos a nível industrial numa granja na cidade de Newberg do estado de Washington (SHAW et al., 2014; STONE, 2011). Estudos descrevem a presença de E.coli $\mathrm{O} 157: \mathrm{H} 7$ durante todas as fases do cultivo do morango. O agente pode sobreviver dentro do solo e em folhas, até a fase da pós-colheita (SHAW et al., 2014). De acordo com um relato feito pelas autoridades de saúde de Oregon, os morangos frescos de uma fazenda foram relacionados com a presença E.coli O157; H7, surto que deixou pelo menos 15 pessoas doentes e causou uma morte (STONE, 2011; SHAW et al., 2015).

Salmonella é gênero de bactéria gram-negativa, pertencente à família Enterobacteriaceae. Possui forma de bastonete intracelular. A maioria movimenta-se por meio de flagelos perítricos (exceto Salmonella gallinarum). É um organismo anaeróbio facultativo não esporulado, apresentando dimensões de 0,7-1,5 x 2,0-5 $\mu \mathrm{m}$. Produz gás por meio da glicose, com exceção de Salmonella typhi. Atualmente, é um dos agentes mais relevantes de doenças transmitidas pelos alimentos (FRANCO; LANDGRAF, 2008). Segundo Caffer (2008), existem diferentes pesquisas com DNA e práticas de hibridação que mostraram que o gênero Salmonella esta constituída por duas espécies: Salmonella entérica e Salmonella bongori. A primeira espécie apresenta seis subespécies: salamae, arizonae, diarizonae, houtenae e indica. Da mesma forma, as subespécies de $S$. entérica e a espécie $S$. bongori se dividem em mais de 2400 sorotipos, definidos em função das diferentes associações dos fatores antígenos somáticos O e flagelares H (CAFFER et al., 2008). No esquema Kauffmann-White a divisão do gênero está baseada em função dos antígenos somáticos "O", antígenos flagelares "H" e os antígenos capsulares "Vi" agrupando as salmonelas mais comumente relacionadas à infecção humana. Além das classificações anteriores as doenças provocadas por Salmonella spp. costumam se subdividir em três grupos: 
Salmonella typh, agente causal da febre tifoide; Salmonella paratyphi, responsável pelas febres entéricas e a Salmonella em geral, causadoras das enterocolites (FRANCO; LANDGRAF, 2008).

Existem relatos, em âmbito mundial, com relação a surtos de Salmonella spp. em diversos alimentos. Muitas espécies são resistentes em condições adversas permanecendo inativas por muito tempo até que as condições sejam favoráveis novamente. Em abril de 2008 foi reportado um surto ligado com Salmonella entérica, sorotipo Saintpaul que originou mais de 1.400 casos nos Estados Unidos e Canadá, através de tomates e pimentas importados do México (KLONTZ et al., 2010). Segundo o relatório da "European Food Safety Authority" (EFSA) de 2010, a Salmonella spp. foi identificada como a causa mais frequente dos surtos de origem alimentar e a segunda doença zoonótica mais frequente nos EUA, sendo a Salmonella enteritidis e Salmonella typhimurium os sorotipos mais associados às doenças humanas (FERNÁNDEZ et al., 2013). Um grande quantitativo de frutas e vegetais frescos tem sido associado a infecções por Salmonella spp. nos últimos anos, como a alface, brotos de sementes, melão, tomate, pimenta e manjericão (BERGER et al., 2010; HEATON; JONES, 2008). Neste mesmo país, a Salmonella spp. tem sido responsável por quase um milhão e meio de infecções relatadas, ocasionando milhares de hospitalizações e centenas de mortes a cada ano (JIN et al., 2008; PATEL et al., 2010). Embora o consumo de morango apresente uma demanda ascendente, também aumentam as preocupações sobre a segurança microbiológica. Conforme o relatado numa pesquisa realizada nos EUA pela "Food and Drug Administration" (FDA), em 1999, descobriu-se que um em cada 143 amostras testadas de morangos importados apontou a presença de Salmonella spp. (HUANG et al., 2013).

\subsubsection{Contagem de Bolores e Leverduras}

Os bolores representam fungos de diferentes gêneros, são eucariotos isto é, possui um núcleo típico no interior de suas células, comparável ao das plantas e animais. São organismos multinucleados, apresentam filamentos conhecidos como hifas que em conjunto formam micélios caracterizados como os principais agentes comuns de decomposição e amolecimento do tecido vegetal, principalmente frutas e vegetais (JAY, 1994). As duas principais funções do micélio são a fixação dos bolores ao substrato (micélio vegetativo) e promoção da reprodução por meio da produção de esporos (micélio reprodutivo). Os fungos perfeitos são o 
resultado da reprodução sexual e os fungos imperfeitos são gerados pela reprodução assexuada, ou ainda, podem estar presentes os dois processos ao mesmo tempo. Encontra-se com maior frequência em frutas e vegetais ácidos com menor teor de vitamina B, e com superfícies discretamente secas, sendo fundamental a presença de ar para o crescimento dos mesmos. (FRANCO; LANDGRAF, 2008). Considera-se a existência de um milhão e quinhentas mil espécies de fungos distribuídas pelo mundo, destas aproximadamente 70 mil espécies de fungos foram até hoje descritas, representando apenas o 5\% do total existente (SILVA, 2008).

Segundo o Compêndio de Doenças do Morango, existem cinquenta e umas espécies de fungos, três de bactérias, oito de nematoides e vinte e seis vírus que provocam doenças nesta cultura (LORENZETTI, 2012). Destacando-se os principais gêneros de bolores que atacam nesta cultura:

O gênero Colletotrichum, possui diferentes espécies que provocam doenças no morango: C. gloesporoides, Colletotrichum fragariae e Colletotrichum gloeosporioides (teleomorph Glomerella cingulata) são as três principais espécies que causam podridão nas frutas e na coroa do morango (MAAS, 1984). É o agente causal de uma das mais importantes doenças do morango, a Antracnose, que provoca danos no caule, folhas, estolões, flores e frutos. Comumente, espécies de Colletotrichum são classificadas com base na morfologia conidial, presença de acévulos, produção de apressório e planta hospedeira de origem (LIU et al., 2007). É muito comum que a doença inicie o desenvolvimento na fase de cultivo, mas os sintomas não aparecem antes do amadurecimento das frutas (ALVAREZ; NISHIJIMA, 1987).

Em morangos, a espécie $C$. acutatum, gera extensas perdas na produção dos frutos (SREENIVASAPRASAD; TALHINHAS, 2005), e é considerado o segundo patógeno mais relevante do mundo depois de Botrytis cinerea em termos de impactos econômicos. Segundo Smith e Black (1986), Colletotrichum acutatum foi identificado pela primeira vez em 1983 em morangos do estado da Califórnia. Desde então, ele se espalhou ao longo de todo o mundo, través do material vegetativo (CALLEJA et al., 2013).

Botrytis é o agente causal da doença conhecida como mofo cinzento, que provoca danos a frutíferas, oleráceas e ornamentais. Este gênero abrange principalmente flores e frutos, porém, pode provocar tombamento em plântulas, manchas foliares e apodrecimento de brotos, bulbos, rizomas, tubérculos e raízes (TÖFOLI et al., 2011). Botrytis cinerea Pers. é a espécie registrada no cultivo de morango. A contaminação pode ocorrer na flor e permanecer 
em repouso até a maduração dos frutos, a partir de então se inicia a multiplicação acelerada deste fungo, causando deterioração das frutas o que causa esporulação abundante do agente patogênico (KOVACH et al., 2000). Este bolor se desenvolve e dissemina-se até em condições de refrigeração, já que a germinação de conídios e o crescimento micelial pode ocorrer a temperaturas baixo $0^{\circ} \mathrm{C}$ (DORBY; LICHTER, 2007; LAHLALI et al., 2007). No Brasil é considerada a doença mais importante em pós-colheita de morango (REIS e COSTA, 2011). Pode causar de $30 \%$ a $40 \%$ de perdas na colheita se não existe algum tipo de controle, no caso de infestações agudas, as perdas podem chegar a $50-60 \%$ até chegar a perdas económicas de 100\% (CSC; CMCC, 2003). Também provoca perdas significativas durante o transporte e comercialização (CEPONIS et al., 1987).

Penicillium spp. também é considerado uma das principais causas de deterioração de uma ampla gama de frutos como peras, maçãs, frutas pequenas, frutas silvestres e até as que têm caroço (SNOWDON, 1990; SOMMER et al., 1994). É considerado um patógeno muito importante para os citros. Provoca grande prejuízo na fase de pós-colheita, e armazenamento. Os bolores mais importantes são o bolor verde, causado por Penicillium digitatum Sacc. e bolor azul, Penicillium italicum Wehmer (PALOU, 2014; KLIMATI et al., 1997).

O patógeno penetra, normalmente, através de feridas ou lesões produzidas durante a colheita e manuseio. A infecção também pode ocorrer através do final da haste, pelo tubo do cálice aberto ou pode ganhar uma entrada através de outros patógenos que causem a primeira infecção. Provocam podridão mole chegando a tomar toda a área. Os frutos muito amadurecidos são susceptíveis à infecção de mofo azul, mesmo em baixas temperaturas de armazenamento de frutas, embora o seu desenvolvimento seja favorecido pelo ambiente quente em locais de varejo e de consumo (MARI et al., 2002).

Os bolores do gênero Rhizopus, possuem micélios cenocíticos e rizóides que ajudam na fixação ao substrato, na absorção de nutrientes e na reprodução assexuada. Os sintomas iniciais são a alteração da cor, o amolecimento do fruto e o escorrimento dos fluidos. Rhizopus stolonifer é a espécie considerada a mais importantes deste gênero, e uma das principais doenças na pós-colheita de morango. Embora a doença não seja observada no campo, as estruturas do fungo podem ser espalhadas pelo vento e insetos das folhas infectadas passam para o fruto, causando a infecção, que geralmente ocorre durante a colheita e o manuseio dos frutos maduros. Devido à grande variedade de hospedeiros que $R$. stolonifer podem infectar e sua rápida penetração e colonização, tornou-se um importante alvo de 
controle na fase de campo. Temperaturas abaixo de $6^{\circ} \mathrm{C}$ evitam a germinação de esporos e temperaturas inferiores a $8^{\circ}-10^{\circ} \mathrm{C}$ produzem uma inibição na produção de esporângios. (KLIMATI et al., 1997; ROMANANZI et al., 2001; CSC e CMCC, 2003; FRANCO; LANDGRAF, 2008; ZHANG et al., 2010).

A presença do fungo Rhizotocnia sp. tem sido associada a uma diversidade de sintomas no morangueiro, provocando severas perdas (MAAS, 1984). É causado pela espécie Rhizoctonia solani Kühn. É caracterizada pela presença de cancros no pseudocaule e podridão das raízes, responsáveis pela diminuição do crescimento e do rendimento da planta (KRISTIC et al, 1997; REIS; COSTA, 2011). Geralmente este fungo contamina os frutos por contato direto com o solo ou por partículas presentes no ambiente, como propágulos do patógeno. Apresentam lesões de cor marrom e firme consistência (KLIMATI et al., 1997).

Os indivíduos classificados como Phythophthora spp. são favorecidos por solos com deficiente drenagem, e quando a fruta entra em contato com o solo, o patógeno Phythophthora cactorum tem facilidade em contaminar o morango (ALVITER et al., 2010). Os frutos podem ser infectados em todos os estágios de desenvolvimento, provocando uma descoloração acastanhada. Numa fase posterior, quando o fruto este maduro as área afetadas sofrem uma depressão, formando em alguns casos uma massa cotonosa. Além disso, em condições de elevada umidade apresentam crescimento de mofo branco fino na superfície do fruto (KLIMATI et al., 1997; MADDEN et al., 1991). Odor e sabor desagradáveis são sintomas evidentes do apodrecimento gerado por este fungo. Há relatos de campos de morango com alta incidência com esta podridão, que podem ter seu odor sentido há uma distância de $250 \mathrm{~m}$. Os frutos maduros infectados têm um gosto amargo e desagradável, que pode ser sentido até mesmo em compotas e geléias (REIS; COSTA, 2011; JELÉN et al., 2005).

As leveduras são fungos predominantemente unicelulares não homogêneos. A grande maioria se reproduz vegetativamente por meio de brotamento das células e menos frequentemente por fissão celular. Essa característica confere às leveduras a capacidade de se reproduzirem aceleradamente sob condições anaeróbias em ambientes líquidos, o que ajuda na dispersão das células, multiplicando-se melhor em condições aeróbias. Apresentam formas esféricas, ovoides, cilíndricas ou triangulares. As leveduras se multiplicam mais lentamente do que as bactérias, não competindo bem em ambientes que permitam o desenvolvimento 
bacteriano, já que precisam de menos umidade do que as bactérias, e de pH ácido (TANIWAKI; SILVA, 2001; FRANCO; LANDGRAF, 2008).

Geralmente, a multiplicação de leveduras está acompanhada pela produção de $\mathrm{CO}_{2} \mathrm{e}$ etanol, mas no processo de deterioração pode-se observar a formação de uma película, turvação, floculação e, em alguns casos, esses microrganismos são capazes de produzir pectinesterases, que atacam a pectina e eliminam a turvação natural dos sucos (ICMSF, 1980 apud FAZIO 2006). A melhor fonte de energia são os açúcares, entretanto as leveduras oxidativas são capazes de oxidar os ácidos orgânicos e álcool. Existem muitos tipos de leveduras que sobrevivem nos alimentos, mas os gêneros mais comuns nas frutas são: Sacharomyces, Hanseniaspora, Pichia, Cândida, Rodotorula, Kloechera e Crypococcus (WILEY, 1997).

A presença de Bactérias Mesófilas Aeróbias, assim como as leveduras, é empregada para indicar a qualidade sanitária dos alimentos. Desenvolvem-se em temperaturas entre 20 e $40{ }^{\circ} \mathrm{C}$. Encontram-se presentes ou não nos alimentos demostrando a inocuidade dos mesmos. Fazem parte deste grupo bactérias: patogênicas e não patogênicas. Geralmente, as bactérias mesófilas estão predominantemente presentes em frutas que são cultivadas e coletadas em temperatura ambiente em países de clima quente, como o Brasil. No caso do morango apresenta elevada quantidade de água e nutrientes, o que torna alvo de diferentes grupos de microrganismos. Além disso, o crescimento de bactérias lácticas e leveduras são favorecidos pelo baixo pH presente nesta fruta (PEREIRA et al., 2010; FRANCO; LANDGRAF, 2008; TORREZAN et al., 2000). Caso ocorra algum tipo de deterioração no fruto, as características organolépticas são afetadas. Há casos de toxinfecção alimentar onde foram encontradas cepas mesófilas de Proteus, Pseudomonas, e Enterococos presentes em números elevados (FRANCO; LANDGRAF, 2008).

\subsection{Parâmetros químicos utilizados na avaliação da qualidade de frutos}

No morango, a qualidade é definida como um conjunto de atributos físicos e qúmicos. A aparência, firmeza, sabor e o valor nutricional são muito importantes e atrativos para o consumidor, sendo estes atributos relacionados com sólidos solúveis totais, $\mathrm{pH}$, acidez, compostos bioativos, compostos fenólicos e ácido ascórbico que influem no sabor e cor do fruto (COSTA, 2009). 


\subsubsection{Sólidos solúveis}

Os sólidos solúveis (SS) são compostos solúveis em água encargados de fornecer a quantidade de substâncias sólidas que se encontram presentes na polpa das frutas. Além disso, são responsáveis pelo sabor, sendo constituído majoritariamente por açúcares, principalmente sacarose, frutose e glicose. Também estão presentes, em menor volume, pectinas, fenólicos, vitaminas, sais, ácidos e aminoácidos e ácidos orgânicos (LUCENA, 2006; CHITARRA, 1999).

Açúcares e ácidos orgânicos têm grande importância entre os componentes químicos da fruta. Os açúcares são em parte responsáveis por o sabor da fruta e determinam o valor calórico de morangos (MONTERO et al., 1996) e estão presentes nos frutos de forma livre ou combinada, sendo os responsáveis pela doçura por meio de um equilíbrio com os ácidos (CHITARRA; CHITARRA, 2005). Entre os diversos componentes da fruta, os sólidos solúveis totais, representados pelo ${ }^{\circ}$ Brix desempenham um papel primordial para a sua qualidade, o que atua como indicador de uma adequada colheita (SILVA, 2011; SILVA et al., 2002; SHAW, 1990).

A quantidade de sólidos solúveis totais no morango varia segundo o estágio de maturação, tendendo a elevar-se conforme aumentam os dias de armazenamento. Os sólidos solúveis também variam conforme a influência de fatores climáticos e as diferentes entre cultivares, variando de 4,5 a $15{ }^{\circ}$ Brix (MOTERO et al., 1996). A determinação do ${ }^{\circ}$ Brix é utilizada nos processos industriais na fabricação de doces, sucos, néctares, polpas, álcoois, açúcares, sorvetes e bebidas em geral, pois quanto maior a quantidade de sólidos solúveis, menor a quantidade de açúcar a ser adicionado no processo industrial (SILVA et al., 2002) .

\subsubsection{Acidez titulável}

A acidez titulável (AT) representa todos os grupos ácidos (ácidos orgânicos livres, na forma de sais e compostos fenólicos) (LUCENA, 2006). Os ácidos orgânicos encontram-se dissolvidos nos vacúolos, de forma livre ou combinados, como sais, ésteres, glicosídeos ou outros compostos (CHITARRA; CHITARRA, 2005). Estão envolvidos no sabor, textura, pH e coloração dos morangos, alterando a qualidade sensorial da fruta (MONTERO et al., 1996). $\mathrm{Na}$ fase de maturação, o teor de ácidos orgânicos, geralmente, tende a decrescer devido à 
oxidação dos ácidos no ciclo dos ácidos tricarboxílicos, consequência da respiração. De modo contrário aos SS, a acidez diminui com o avanço da maturação (OLIVEIRA, 2005). Segundo Shaw (1990), o aroma do morango vai depender, em parte, do equilíbrio entre o teor de sólidos solúveis e o titulável acidez expressada na fruta madura

\subsection{3 pH}

$\mathrm{O}$ pH é constituído pela concentração hidrogeniônica da solução, fator intrínseco do alimento, que desempenha papel de seleção sobre a microflora mais apta a desenvolver-se. A medida do $\mathrm{pH}$ é importante para a avaliação de deterioração presente no alimento, como o crescimento de microrganismos, atividade das enzimas, retenção de sabor e odor de produtos (LUCENA, 2006).

\subsubsection{Compostos Bioativos}

As frutas do morango possuem compostos bioativos que apresentam relação com o sistema de defesa da planta no ataque de pragas, patógenos, radiação solar. A maioria desses compostos são constituintes extranutricionais que ocorrem tipicamente em pequenas quantidades nos alimentos, porém com uma grande diversidade e são subdivididos em grupos com milhares de compostos distintos (HORST; LAJOLO 2009). Forma parte deste grupo os compostos polifenoides, vitamina $\mathrm{C}$, ácido fólico, os quais apresentam capacidade antioxidante, relevante in vitro e in vivo (WANG e LIN, 2000; SKALZO et al., 2005).

Os polifenóides pertencem ao grupo dos metabólitos secundários e operam como moduladores do desenvolvimento da planta, por meio do controle do ácido indolacético (IAA) (GARCIA et al., 1992). Têm a capacidade de aumentar a rigidez da parede celular, atuando como pontes moleculares entre os componentes da parede celular (FRY, 1986; SEERAM et al., 2006, TULIPANI et al., 2008).

Da classe dos flavonoides presentes no morango, o mais destacado é o grupo das antocianinas, consideradas como grupo de pigmentos solúveis em água, sendo responsáveis pela atrativa cor vermelha do morango (PINELI et al., 2011). Segundo Zabetaki et al.,(2000), as principais antocianinas do morango são a pelargonidina-3-glucósido e a cyanindin-3glucósido. Possuem grande capacidade antioxidante devido sua estrutura química que 
apresenta três anéis com ligas duplas conjugadas e hidroxilas dispostas ao longo da cadeia, sendo os responsáveis pela captura de radicais livres para evitar danos celulares e doenças degenerativas (KONG et al., 2003).

\subsubsection{A vitamina $\mathbf{C}$}

A vitamina $\mathrm{C}$ ou ácido ascórbico desempenha um papel antioxidante importante na regeneração dos músculos, pele, dentes e ossos, na regulação da temperatura corporal, na absorção de ferro e oferecendo proteção contra diferentes doenças de aspecto degenerativo, além do envelhecimento. Esta vitamina é uma das treze principais vitaminas que formam um complexo necessário para o adequado funcionamento do organismo humano. Além disso, têm propriedades hidrossolúveis, o que permite ao organismo eliminar o excesso de concentração destas (BRAVERMAN, 1967; BERVARI, 1992).

A deficiência desta vitamina provoca vulnerabilidade a doenças como o escorbuto. No entanto, o excesso do consumo pode ocasionar diarreia, dor abdominal e cálculos renais. Esta vitamina é capaz de dar e receber elétrons exercendo o rol antioxidante (OLIVEIRA, 1998). O corpo humano não tem a capacidade de sintetizar esta vitamina, sendo necessário adicionar à dieta alimentar, por meio do consumo de frutas e verduras. Especialistas do Instituto Nacional da Saúde (National Institute of Health), através de publicação no Journal of the American Medical of Health indicaram o aumento de vitamina C de 60mg para 100 a 200 mg por dia (SILVA, 2007; PINELI, 2009; SMIRNOFF, 1996; LEE, 2000).

O morango é uma valiosa fonte de vitamina C, possuindo elevada quantidade, variando entre 39 a $89 \mathrm{mg}$ em 100 gramas de fruta, in natura, tendo um valor médio de $60 \mathrm{mg}$ em cada 100 gramas de morango, estes valores podem variar por diversos fatores como a cultivar, estágio de maturação, época, condições de cultivo e armazenamento (CHITARRA, 1999).

\subsection{Métodos de sanitização do morango}

A armazenagem do morango com tecnologias adequadas é muito importante para o controle dos padrões microbiológicos sanitários e a conservação da qualidade dos frutos. Por 
esta razão, existem vários processos de sanitização disponíveis, para que o produto mantenha as suas características físico-químicas e microbiológicas durante o armazenamento, não apresentando risco ao consumidor.

No Brasil, a legislação tem admitido o uso de produtos clorados e alguns derivados para os processos de sanitização nos alimentos na fase de pós-colheita. No entanto, outros países possuem mais de um método de sanitização garantidos como seguros, "Generally Recognized as Safe" (GRAS, 1997).

O cloro e seus derivados são amplamente utilizados nos processos de sanitização na etapa pós-colheita, além disso, é o principal desinfetante no tratamento de água potável (SAWYER et al., 1994). Porém, o uso descontrolado pode provocar algumas desvantagens como: descoloração do alimento e perda da qualidade (MORETTI, 2007; PARISH, et al., 2003). Existem pesquisas que indicam formação de subprodutos químicos mutagênicos, tóxicos e carcinogênicos em água, alimentos e superfícies de contato (SILVA et al., 2011; NASCIMENTO; SILVA 2010; SILVEIRA et al., 2008). O uso de cloro em forma de gás é corrosivo, e em altas concentrações de hipoclorito são instáveis, o que pode gerar clorados como subprodutos, além de menos eficaz em ambientes com pH ácido (EPA, 1999).

O ácido peracético é outro método usado na sanitização do morando. Provoca oxidação da parede da célula microbiana, danos ao sistema enzimático e, consequentemente, inativação da célula microbiana. Além disso, apresenta baixa estabilidade à estocagem (BRACKET, 1987; KOSEKI et al., 2004; YU et al.,2001).

Entre os métodos físicos de sanitização, destaca-se a aplicação de calor (seco, vapor e imersão), porém, alguns produtos geram alterações nutricionais, sensoriais, de textura e de aroma (RICO et al., 2007). Outro método físico é a radiação ultravioleta na faixa de 200 a 280 $\mathrm{nm}$, classificada como UV-C, que apresenta capacidade para reduzir podridões durante o armazenamento (CAMILI et al., 2005). Embora apresentem efeitos positivos, a UV-C também produz efeitos não desejáveis como a descoloração da casca em tomates (LIU et al., 1993) e o escurecimento em morangos e em mamões (MARQUENIE et al., 2002). Diante dos problemas apresentados pelos métodos de conservação anteriormente citados, observa-se a necessidade de estudar novos métodos de sanitização como a aplicação de alta pressão hidrostática; campo elétrico pulsado de alta intensidade; ultrassom e o ozônio, que é permitido 
na Europa, como desinfetante de água para o consumo humano, desde 1893 (PRESTES, 2007).

Atualmente, existem inúmeras áreas de aplicação de ozônio a nível industrial, tais como higiene da superfície de alimentos, saneamento dos equipamentos de indústrias de alimentos, possibilitando a reutilização das águas residuais (GUZEL-SEYDIM et al., 2004). O ozônio tem várias características que podem ser utilizados para melhorar a qualidade de pós-colheita de produtos hortícolas, sendo quimicamente reativo e exercendo atividade antibiótica significativa sobre uma variedade de organismos de deterioração, incluindo fungos e bactérias (HOWART et al., 1994). O uso de ozônio na etapa de pós-colheita possibilita a conservação dos produtos com altos parâmetros de qualidade microbiológica e física, já que o ozônio possui elevado potencial de oxidação, podendo oxidar contaminantes no ar e na água. É eficiente contra germes e vírus e, pode ser aplicado em forma gasosa ou dissolvido na água. É considerada uma grande vantagem, pois possibilita a liberação de oxigênio no processo de degradação (DI BERNARDO, 2007).

\subsection{O Ozônio}

\subsubsection{Historia}

O ozônio foi descoberto em 1785 pelo cientista holandês Vom Marum, que submeteu oxigênio puro e ar atmosférico a intensas descargas elétricas, obtendo uma redução do volume do gás e observando que durante as descargas, originaram-se reações químicas produzindo um gás com odor característico (HILL; RICE, 1982). Em 1840, Chirtian Schönbein, continuou os experimentos do holandês, patrocinado por uma patente americana, testada por Fewson em 1888 na desodorização de gases de esgoto.

Na França, em 1906, foi estabelecida a primeira estação de tratamento de água potável com uso do ozônio. Na Alemanha, em 1910, o ozônio foi usado em fábricas de embalagem de carne. Nos Estados Unidos, utilizou-se primeiramente em 1918, para desinfetar piscinas, em seguida, em 1940 foi utilizado em aproximadamente 350 estações de tratamento de água e em 1942 a nível industrial foi aproveitado em salas de armazenamento de ovos e em instalações de armazenamento de queijo. Novamente na Alemanaha, em 1972, o ozônio foi usado para tratar aguas residuais. Em 1977, na Rússia, utilizou-se o composto para reduzir a quantidade 
de Salmonella em ovos com casca. No ano de 1982, a GRAS (Geralmente Reconhecido como Seguro), para garrafas de água em Estados Unidos sendo reafirmado em 1995. O Instituto de Pesquisa de Energias Elétricas (EPRI), em 1997 em conjunto com um grupo de especialistas, declarou GRAS no processamento de alimentos nos Estados Unidos, permitindo em 2001, o uso de ozônio como um agente antimicrobiano no tratamento, armazenamento e processamento de alimentos (GRAHAM, 1997; GUZEL-SEDYDIM, 2004; SOPHER et al., 2002). Estima-se que no ano 2001 já havia 3.000 instalações de tratamento de água a base de ozônio a nível mundial (KHADRE; YOUSEF, 2001).

\subsubsection{Propriedades físico-químicas}

A composição química do ozônio $\left(\mathrm{O}_{3}\right)$ é caracterizada pela forma triatômica alotrópica de oxigênio, gerada pela transformação de oxigênio molecular em oxigênio atômico, ambos presentes em um ambiente de carga elétrica. Possibilita a recombinação, onde o átomo de oxigênio central se liga a dois átomos de oxigênio equidistantes. É um gás incolor, instável, reativo e tóxico, possui odor característico, pode ser facilmente detectado em concentrações de 0,02-0,1 $\mathrm{mg} \mathrm{m} \mathrm{m}^{3}$. Os níveis máximos permitidos, segundo a Associação Americana de Higiene Industrial (AIHA) e a Administração de Saúde e Segurança Ocupacional (OSHA), são $0,2 \mathrm{mg} \mathrm{m}^{-3}$ durante 8 horas no dia ou $0,6 \mathrm{mg} \mathrm{m}^{-3}$ por 10 minutos (PONCE et al., 2007; NOVAK., et al 2007).

O ozônio é aproximadamente $50 \%$ mais denso que o oxigênio, com uma massa molecular igual a 48 , condensando-se a $-112,4^{\circ} \mathrm{C}$. O ponto de congelamento é $-251,4{ }^{\circ} \mathrm{C}$, formando um sólido de cor violeta escuro. Sua decomposição é muito rápida, e a temperaturas acima de $100^{\circ} \mathrm{C}$ apresenta propriedade explosiva (KIM, 1999; KHADRE; YOUSEF, 2001; REBOUÇAS; GONÇALVES, 2013). A maior característica do ozônio, além de ser uma grande vantagem, é não deixar efeito residual no produto e, dessa forma, não apresenta risco para a saúde do consumidor e não contamina o ambiente. Na água, o principal oxidante intermediário formado a partir da decomposição de ozônio é o radical hidroxila $(\mathrm{OH}-)$ (HOIGNE; BADER, 1975; SILVEIRA, 2004).

De acordo com a Tabela 3, o ozônio é um potente agente oxidante (2,07 mV), que apresenta características físico-químicas que permitem também sua utilidade no tratamento de 
efluentes industriais, desinfecção de equipamentos (DOSTI et al.,2005), descontaminação dos alimentos (ARTES et al., 2009) e armazenamento dos grãos (ROZADO et al., 2008).

Tabela 2 - Diferentes agentes oxidantes e os respetivos potenciais de oxidação

\begin{tabular}{lc}
\hline Desinfetantes & Potencial de oxidação (mV) \\
\hline Ozônio & 2,07 \\
Flúor & 3,06 \\
Peróxido de hidrogênio & 1,78 \\
Permanganato & 1,67 \\
Dióxido de cloro & 1,5 \\
Hipoclorito & 1,49 \\
Cloro & 1,36 \\
\hline
\end{tabular}

Fonte: Manley et al.,1967 apud Guzel-Seydim; Greene; Seydim, 2004.

O ozônio como agente desinfetante, atua inicialmente rompendo a membrana ou parede celular; reagindo com vários constituintes como as glicoproteínas, glicolipídeos e enzimas, interagindo com substâncias presentes no citoplasma e no núcleo, degradando purinas e pirimidinas do DNA, produzindo a desnaturação dos componentes celulares causando sua ruptura e morte celular no mínimo tempo de contato e inibindo a recuperação dos micro-organismos após o ataque (CHIATTONE et al., 2008).

Segundo Graham (1997), o ozônio atua na conservação e descontaminação de frutas e legumes, atuando como um biocida contra bactérias Gram-positivas (Listeria monocytogenes, Staphylococcus aureus, Enterococcus faecalis), bactérias Gram-negativas (Escherichia coli, Salmonella Typhimurium, Yersinia enterocolitica, Pseudomonas aeruginosa), vírus, fungos (Cândida parapsilosis, Candida tropicalis) e esporos de bactérias (Bacillus cereus). Dependendo do tipo de micro-organismo, o ozônio pode atuar até 3.125 vesses mais rápido do que o cloro na desativação celular (GOULART, 2011). A aplicação de ozônio em frutas tem possibilitado aumento da vida de prateleira. Em maçãs, por exemplo, o tratamento com ozônio resultou em menor perda de peso e deterioração, provavelmente em razão da oxidação do etileno (GUZEL-SEDYDIM, 2004).

O processo mais utilizado para a geração de ozônio a nível industrial é o método de descarga por efeito corona, sendo o mais difundido e empregado comercialmente. O ozônio é 
gerado pela passagem de oxigênio puro entre dois eletrodos submetidos a uma elevada carga elétrica (aproximadamente $10.000 \mathrm{~V}$ ), ocasionando a dissociação do oxigênio. A recombinação de radicais livres de oxigênio, com moléculas de oxigênio presentes no sistema origina o ozônio (METCALF; EDDY, 1991).

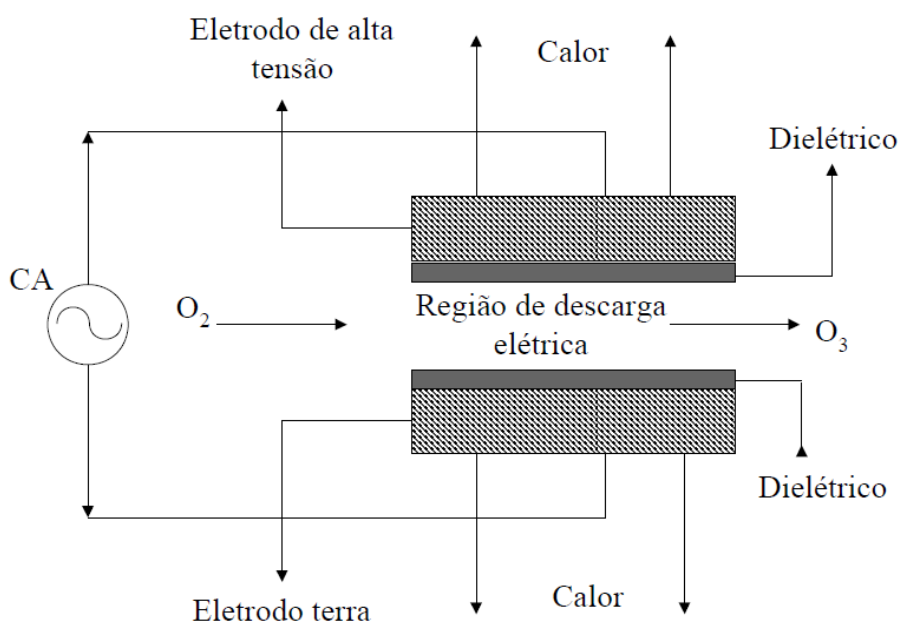

Figura 2 - Esquema do principio de geração de ozônio baseado no método de efeito corona. Fonte: Hotz (2006)

O ozônio no processo da pós-colheita não é usado somente para inativar microrganismos, mas também para a degradação de aflatoxina B1 e o controle de pragas (HABIBI et al., 2009). Este método de descontaminação tem a vantagem de ser muito mais barato em comparação com métodos como a radiação, por exemplo. Com o uso do ozônio, as verduras e frutas comercializadas tem apresentado um elevado grau de pureza microbiológica que ajuda a proteger a saúde do consumidor (BRODOWSKA; ŚMIGIELSKI, 2013). Nos EUA, as principais empresas embaladoras de maçãs em Ohio têm substituído o uso de cloro pela aplicação de ozônio, aumentando o controle de micro-organismos e o reaproveitamento da água. A empresa instalou um sistema de tratamento com ozônio na água melhorando as operações e economizando mais de 12.000 litros de água por semana, já que esta é reutilizada e não substituída diariamente (SOPHER et al., 2002). 


\section{REFERÊNCIAS BIBLIOGRAFICAS}

ALCÂNTARA, E. M. Caracterização física, química e microbiológica de morango, alface e cenoura. 2009. 124 f. Dissertação (Mestrado em Ciências dos Alimentos) - Universidade Federal de Lavras, MG. 2009.

ALVAREZ, A.M.; NISHIJIMA, W.T. Postharvest diseases of papaya. Plant Disease, v.71, n.8, p. 681-686, 1987.

ALVITER, R. L.; WILSON, L.; MADDEN, L. V.; ELLIS, M.A. A. C. A Comparative evaluation of post-infection efficacy of mefenoxam and potassium phosphite with protectant efficacy of azoxystrobin and potassium phosphite for controlling leather rot of strawberry caused by Phytophthora cactorum. Crop Protection, v. 29, p. 349-353, 2010.

ANDRADE, C. Cultivo orgânico de morango muda qualidade de frutos. Agência Universidade São Paulo. Piracicaba. Agência USP de Notícias. 2014.

ANDRIGUETO, J. R.; NASSER, L.C.B.; TEIXEIRA, J.M.A.; SIMON, G.; VERAS, M.C.V.; MEDEIROS, S.A.F. Produção Integrada de Frutas. PIF e Sistema Agropecuário de Produção Integrada - SAPI no Brasil. Ministério da Agricultura; 2008.

ANTUNES, L. E. C.; FILHO, J. D. Sistema de Produção do morango. Sistemas de Produção. v. 5, Embrapa Clima Temperado, p. 63, 2005.

ANTUNES, L. E. C.; PERES, N. A. Strawberry production in Brazil and South America.International Journal of Fruit Science, v. 13, n.1-2, p.156-161, 2013.

ANTUNES, L. E. C.; REISSE R JÚNIOR, C. Fragole i prodottori brasiliani mirano all' esportazione in Europa. Frutticoltura (Bologna), v. 69, p. 60-65, 2007.

ARTÉS, F.; GÓMEZ, P.; AGUAYO, E.; ESCALONA, V.; ARTÉS-HERNÁNDEZ, F. Sustainable sanitation techniques for keeping quality and safety of fresh-cut plant commodities. Postharvest Biology and Technology, v.51, p. 287 - 296, 2009.

BASU, T. K.; SCHORAH, C. J. Vitamin $\mathbf{c}$ in health and disease Londres: AVI Pub. Co., 1982. $152 \mathrm{p}$.

BERBARI, S. A. G. Avaliação da qualidade de algumas variedades de morango para o processo de congelação. 1992. 90 f. Dissertação (Mestrado em Ciências). Escola Superior de Agricultura Luiz de Queiroz, Piracicaba, SP. 1992.

BERGER, C.N.; SODHA, S.V.; SHAW, R.K.; GRIFFIN, P.M.; PINK, D.; HAND, P.; FRANKEL, G. Minireview: fresh fruit and vegetables as vehicles for the transmission of human pathogens. Environmental Microbiology, v. 12, n. 9, p. 2385- 2397, 2010.

BOLLEN, G.J. The fate of plant pathogens during composting of crop residues. In: GASSER, J.K.R. (Ed.). Composting of agricultural and other wastes. London: Elsevier Applied Science. 1985. 
BRACKETT, R.E. Microbiological consequences of minimally processes fruits and vegetables. Journal of Food Quality, v.10, p. 195-206, 1987.

BRAHM, R.U.; OLIVEIRA, R.P. Potencial de multiplicação in vitro de cultivares de morangueiro. Revista Brasileira de Fruticultura, v.26, n.3, p.507-510, 2004.

BRANZANTI, E.C. La fresa. Mundi - Prensa: Madrid, 1989. 386p.

BRASIL. AGÊNCIA NACIONAL DE VIGILÂNCIA SANITÁRIA. Resolução RDC $\mathrm{n}^{\circ} 12$, de 02/01/2001. Regulamento Técnico sobre padrões microbiológicos para alimentos. Diário Oficial da República Federativa do Brasil, Brasília, DF, 10 jan. 2001, Seção I, p. 45-53.

BRASIL. Decreto $\mathrm{n}^{\circ}$ 4.074, de 04 de janeiro de 2002. Diário Oficial da República Federativa do Brasil, Brasília, DF, 2002 jan. Disponível em: http://www.planalto.gov.br/ CCIVIL_03/decreto/2002/D4074.htm. Acesso: 20 de janeiro de 2015.

BRAVERMAN, J. B. S. Vitaminas. In: Introducción a la bioquímica de los alimentos. Omega: Barcelona, p.206-241, 1967.

BRODOWSKA, A. J.; ŚMIGIELSKI, K. Ozonation - an alternative decontamination method for raw plant materials. Biotechnology of Food Scient, v.77, n.1, p.37-43, 2013.

CAFFER, M. I.; TERRAGNO, R.; BINSZTEIN. Manual de Procedimientos Diagnóstico y Caracterización de Salmonella spp. Departamento Bacteriología Instituto Nacional de Enfermedades Infecciosas A.N.L.I.S. "Dr. Carlos G. Malbrán" Centro Regional de Referencia del WHO Global Salm Surv para América del Sur. 2008. 37p.

CALLEJA, J. E.; ILBERY, B.; SPENCE, N.J.; MILLS, P.R. The effectiveness of phytosanitary controls in preventing the entry of Colletotrichum acutatum in the UK strawberry sector. Plant Pathology, v.62, p. 266-278, 2013.

CAMARGO, L. Produtividade e qualidade de cultivares de morangueiro em sistemas orgânico e convencional na região de Guarapuava-PR. 2008. 86 f. Dissertação (Mestrado em Agronomia)-Universidade Estadual do Centro-Oeste, Guarapuava-PR. 2008.

CAMILI, E.C.; CIA, P.; BENATO, E.A. Indução de resistência contra doenças pós-colheita. In: CAVALCANTI, L.S.; DI PIERO, R.M.; CIA, P.; PASCHOLATI, S.F.; RESENDE, M.L.V. de; ROMEIRO, R.S. (Org.). Indução de resistência em plantas a patógenos e insetos. 1. ed. Piracicaba: Fealq, 2005. p. 195-218.

CEPONIS, M.J.; CAPPELLINI, R.A.; LIGHTNER, G.W. Disorders in sweet cherry and strawberry shipments in the New York market, 1972-1984. Phytopathology. p. 472-475, 1987.

CHANDLER, C. K.; LEGARD, D. E.; DUNIGAN, D.D. Strawberry Festival' Strawberry. Horticultural Science, v. 35, n. 7, p. 1366-1367, 2000.

CHIATTONE, P.; TORRES, L.: ZAMBIAZI, R. Aplicação do ozônio na indústria dos alimentos. Departamento de Ciência e Tecnologia Agroindustrial . Universidade Federal de Pelotas. 2008. 
CHITARRA, A. B. Armazenamento de frutos e hortaliças por refrigeração. Lavras. UFLA: FAEPE. 1999. 62 p.

CHITARRA, M. I. F.; CHITARRA, A. B. Pós-colheita de frutas e hortaliças: fisiologia e manuseio. Lavras: UFLA. $2^{a}$ Ed., 2005, 256p.

COSTA, F. B. Fisiologia da conservação de cultivares de morangos inteiros e minimamente processados. 2009. 115 f. Tese (Doutorado em Fisiologia Vegetal)Universidade Federal de Viçosa, Viçosa, MG. 2009.

CSC (California Strawberry Commission) and CMCC (The California Minor Crops Council) A Pest Management Strategic Plan for Strawberry Production in California. 2003.

DARROW, G.M. 1966. The strawberry. History, breeding and physiology, Holt, Rinehart and Winston, New York p. 447

DI BERNARDO, L.; BRANDAO, C.; HELLER, B. Tratamento de águas de abastecimento por filtração em múltiplas etapas. 2007. 121p.

DORBY, S.; LICHTER, A. Post-harvest Botrytis infection: etiology, development and management. In: ELAD, Y.,WILLIAMSON, B., TUDZYNSKI, P., DELEN, N. (Eds.), Botrytis: Biology, pathology and control. Dordrecht: Springer, 2007. p. 223-242.

DOSTI,B.; GUZEL, Z.; GREENE, A. Effectiveness of ozone, heat and chlorine for destroying common food spoilage bacteria in synthetic media and biofilms. International Journal of Dairy Technology, v.58, p. 19-24, 2005.

DUBREUIL, J. D. Escherichia coli - Enterotxigenic E. coli (ETEC). Encyclopedia of Food Microbiology. 2da edição, 2014. p 728 - 734.

DULEY, R. Agricultura orgânica, biodinâmica, natural, agroecológica ou ecológica. Informações econômicas, v.33, n.10, 2003.

EFSA, European Food Safety Authority, 2010. The community summary report on trends and sources of zoonoses, zoonotic agents and food-borne outbreaks in the European Union in 2008. EFSA Journal v.8, p. 1496.

EPA: Eviromental Protection Agency. Alternative Disinfectants and oxidants Guidance Manual. United States. 1999.

EPA: United States Environmental Protection Agency. About pesticides. Disponível em: http://www.epa.gov/pesticides/about/index.htm. Acesso em: 12 de outubro de 2014.

FAO- Food and Agricultural commodities production. Disponível em: http://faostat.fao.org/site/339/default.aspx. Acesso em: 20 de dezembro 2014.

FAZIO, M. L. S. Qualidade microbiológica e ocorrência de leveduras em polpas congeladas de frutas. 2006. 132 f. Dissertação (Mestrado em Ciências e Tecnologia de Alimentos) - Universidade Estadual Paulista Júlio de Mesquita Filho, São José de Rio Preto, SP. 2006. 
FDA: Food and Drug Administration. Secondary direct food additives permitted in food for human consumption. Federal Register, v.66, n.123, p.33829-33830, 2001.

FERNANDES, M. Empresa de Assistência Técnica e Extensão Rural do Estado de Minas Gerais $2009 \quad$ Disponível em: <http://www.emater.mg.gov.br/portal.cgi?flagweb=site_tpl_paginas_internas\&id=1363>. Acesso em: 22 de novembro de 2013.

FERNÁNDEZ, A.; NORIEGA, E.; THOMPSON, A. Inactivation of Salmonella enterica serovar Typhimurium on fresh produce by cold atmospheric gas plasma technology. Food Microbiology, v. 33, p. 24-29, 2013.

FERREIRA, D.F. Sisvar: a computer statistical analysis system. Disponível em: http://www.dex.ufla.br/ danielff/softwares.htm. Acesso em: 28 de janeiro de 2014.

Ficha técnica el cultivo de la fresa. Disponível em: <www.agrolalibertad.gob.pe/.../Ficha\%20Técnica\%20>, Acesso em: 1 de novembro de 2013.

Fórum Global, 1992, Tratado das ONGs relativo à agricultura sustentável, documento 10, Rio de Janeiro.

FREEMAN,B. Institute for Food Safety and Health Illinois Institute of Technology. Disponível em:https://www.iit.edu/magazine/spring_2011/pdfs/spring11_researchbriefs.pdf Berry Health Benefits Symposium Westlake Village CA, 2011. Acesso em 14 dezembro de 2014.

FRY, S.C. Cross-linking of matrix polymers in the growing cell walls of angiosperms. Annual Review Plant Physiology, v. 37, p. 165-166, 1986.

GARCIA, F.; CALDERON,A.; MUÑOZ R,; ROS B. The decarboxylative pathway of indole3 -acetic acid is not functional in grapevine protoplasts. Journal of Experimental Botany, v.43, n.5, p.715-721, 1992.

GAZZONI, D.L. Alimentos Melhores e Mais Seguros. Disponível em: http://catir.agricultura.gov.br/dotlrn/clubs/deprossistemaagropecuariodeproduo integrada $>>$ comunidadedoscoordenadores/news/item?item_id=417685. 2006. Acesso em: 03 de dezembro de 2013.

GIAMPIERI, F.; TULIPANI, S.; ALVAREZ, J.; QUILES, J.; MEZZETTI, B.; BATTINO, M.; The strawberry: Composition, nutritional quality, and impact on human health. Nutrition, p. 9-19, 2012.

GOULART, A.C Ozônio. Disponível em: ttp://www.snatural.com.br/ Ozonio.htm. 2011. Acesso em: 24 de fevereiro de 2014.

GRAHAM, D.M. Use of ozone for food processing. Food Technology, v.6, n.51, p.72-75, 1997.

GUIMARÃES, A.G.; ANDRADE, V.C.; PASCUAL.M. Estimativa da quantidade de DNA em morangueiro. Current Agricultural Science and Technology, v.19, p.19-23, 2013. 
GUZEL-SEYDIM, Z. B.; GREENE, A. K.; SEYDIM, A. C. Use of ozone in the food industry. Lebensm.-Wiss. u. - Technology, v.37, p. 453-460. 2004.

HABIBI NAJAFI, M. B. H.; KHODAPARAST M.H. Efficacy of ozone to reduce microbial populations in date fruits. Food Control, v.20, p. 27-30, 2009.

HALVORSEN, B.L.; HOLTE, K.; MYHRSTAD, M.C.; BARIKMO, I.; HVATTUM, E.; REMBERG, S.F.; WOLD, A.B.; HAFFNER, K.; BAUGERØD, H.; ANDERSEN, L.F.; MOSKAUG, Ø.; JACOBS, D.R. J.; BLOMHOFF, R. A systematic screening of total antioxidants in dietary plants. Journal Nutrition, v.132, p.461-471, 2002.

HEATON, J.C.; JONES, K. Microbial contamination of fruit and vegetables and the behaviour of enteropathogens in the phyllosphere: a review. Journal of Applied Microbiology, v.104, p. 613-626, 2008.

HENNION, B.; VESCHAMBRE, D. La fraise: Maîtrise de la production. Paris, France, p. 299, 1997.

HENRIQUES, A.; BASSANI,V.; RASEIRA, M.; ZUANAZZI, J. Antocianinas e Capacidade Antioxidante de Frutas. $2^{\circ}$ Simpósio Nacional do Morango. $1^{\circ}$ Encontro de Pequenas Frutas e Frutas Nativas. Pelotas - Rio Grande do Sul. p. 271, 2004.

HENZ, G. P. Desafios enfrentados por agricultores familiares na produção de morango no Distrito Federal. Horticultura Brasileira, v. 28, n. 3, p. 260-265, 2010.

HESPANHOL, R. A. M.; BARBOSA, S. A. Formas alternativas de produção: a agricultura orgânica no Município de Presidente Prudente- SP. Campo Território: revista de geografia agrária, v. 6, n. 12, p.200-223, 2011.

HILL,A.; RICE,R.; Handbook of Ozone Technology and Applications. Michigan, 1982.

HOIGNE, J.; BADER, H. Ozonation of water: Role of hydroxyl radicals as oxidizing intermediates. Science, v. 21, n. 4216, p. 782-784, 1975.

HORST, M.A.; LAJOLO, F.M. Biodisponibilidade de compostos bioativos em alimentos. In: FRANCISCATOCOZZOLINO, S.M.F. (Org.). Biodisponibilidade de nutrientes. 3 ed. São Paulo: Ed. Manole, 2009. 1368 p.

HOWARD, R.J.; GARLAND, J.A.; SEAMAN, W.L Diseases and Pests of Vegetable Crops in Canada: An Illustrated Compendium. Canadian Phytopathological Society and Entomological Society of Canada, M.O.M. Printing Ltd., Ottawa, Canada. 554p. 1994.

HUANG, Y.; YE, M.; CHEN, H. Inactivation of Escherichia coli O157:H7 and Salmonella spp. in strawberry puree by high hydrostatic pressure with/without subsequent frozen storage. International Journal of Food Microbiology, v. 160, p 337-343, 2013.

HUMMER, K.; NATHEWET, P.; YANAGI, T. Decaploidy in Fragaria iturupensis Staudt (Rosaceae). American Journal of Botany, v. 96, p. 713-716, 2009. 
ICMSF- International Commission on Microbiological Specification for Foods. Microorganisms in foods 6: Microbial ecology of food commodities. Blackie Academic \& Professional, London, 1998.

ILBERY, B.W. Agricultural change on the West Midlands urban fringe. Tijdschrift voor Economische en Sociale Geografie, v. 79, n.2, p. 108-121, 1998.

INSTITUTO BRASILEIRO DE FRUTAS (IBRAF) Disponível em: /http://www.ibraf.org.br/estatisticas/Exporta\%C3\%A7\%C3\%A3o/Comparativo_das_Exporta \%C3\%A7\%C3\%B5es_Brasileiras_de_Frutas_frescas_2010-2009.pdf//. Acesso em: 19 de dezembro 2014.

INSTITUTO DE PROMOCÃO E DESENVOLVIMENTO (IPD) Disponível em: //http://www.ipd.org.br/pt-br/noticia/21/brasil-tem-area-de-7114300-hectares-de-producaoorganica-certificada-para-o-mercado-externo// .Acesso em 12 janeiro de 2014.

JARDIM, I.C.S.F.; ANDRADE, J.A.; QUEIROZ, S.C.N. Resíduos de agrotóxicos em alimentos: uma preocupação ambiental global - um enfoque às maçãs. Química Nova. v. 32, n. 4, p. 996-1012, 2009.

JAY, J.M. Microbiologia moderna de los alimentos. 3.ed. Zaragoza: Acríbia, 1994. 606p.

JELÉN, H.H.; KRAWCZYK, J.; LARSEN, T.O.; JAROSZ, A.; GOLEBNIAK,B. Main compouds responsible for off-odour of strawberries infected by Phithophthora cactorum. Letter in Applied Microbiology, v. 40, n.4, p. 255-259, 2005.

JIN, T.; ZHANG, H.; BOYD, G.; TANG, J. Thermal resistance of Salmonella enteritidis and Escherichia coli K12 in liquid egg determined by thermal-death-time disks. Journal of Food Engineering, v. 84, p. 608-614, 2008.

KHADRE, M. A.; YOUSEF, A. E. Decontamination of a multilaminate aseptic food packaging material and stainless steel by ozone. Journal Food Safety, v. 21, n. 1, p.1-13, 2001.

KIM, J.G; YOUSEF, A.E.; DAVE, S. Application of ozone for enhancing the microbiological safety and quality of foods: a review. Journal Food Protection, v. 62, n. 9, p. 1071-1087, 1999.

KLIMATI, H.; AMORIN, L.; BERGAMIN FILHO, A.; CAMARGO, L.E.A.; RESENDE, J.A.M. Manual de Fitopatologia: Doenças das plantas cultivadas. São Paulo: Ceres 1997. $706 \mathrm{p}$.

KLONTZ, K. C., KLONTZ, J. C., MODY, R. K., HOEKSTRA, R. M. Analysis of tomato and jalapeño and serrano pepper imports into the United States from Mexico before and during a national outbreak of Salmonella serotype Saintpaul infections in 2008. Journal of Food Protection, v.73, n.11, p.1967-1974, 2010.

KONG, J. M.; CHIA, L.S.; GOH, N. K.; CHIA, T. F.; BROUILLARD. R. Analysis and biological activities of anthocyanins. Phytochemistry, 2003 v. 64, n. 5, p. 923-933. 
KOSEKI, S.; ISOBE, S.; ITOH, K. Efficacy of acidic electrolyzed water ice for pathogen control on lettuce. Journal Food Protection. v.67, p. 2544-2549, 2004.

KOVACH, J.; PETZOLDT, R.; HARMAN, G.E. Use of honey bees and bumble bees to disseminate Trichoderma harzianum 1295-22 to strawberries for botrytis control. Biology Control, v.18, p. 235-242, 2000.

KRISTIC, B.; VICO, M.; TOSIC, M.; STOJANOVIC, G. Peroxidase Isoenzymes in Strawberry Roots infected with Binucleate Rhizoctonia spp. And their Implication in Disease Resistance. Journal Phythopatology, v. 145, p. 429-433, 1997.

LAHLALI, R., SERRHINI, M.N., FRIEL, D., JIJAKLI, M.H. Predictive modelling of temperature and water activity (solutes) on the in vitro radial growth of Botrytis cinerea International Journal of Food Microbiology, v. 114, p.1-9, 2007.

LAZAROVA, V.; SAVOYE, P.; JANEX, M. Advanced wastewater disinfection technologies: state of the art and perspectives. Water Science and technology, v. 40. p. 201213. 1999.

LEE, S.K.; KADER, A. A. Preharvest and postharvest factors influencing vitamin C content of horticultural crops. Postharvest Biology Technology, n.20, p.207-220, 2000.

LIU, G.; KENNEDY, R.; GREENSHIELDS, D. L.; PENG, G.; FORSEILLE, L.; SELVARAJ, G.; WEI, Y. Detached and Attached Arabidopsis Leaf Assays Reveal Distinctive Defense Responses Against Hemibiotrophic Colletotrichum spp. Molecular Plant-Microbe Interactions , p. 1308-1319, 2007.

LIU, J.; STEVENS, C.; KHAN, V.A.; LU, J.Y.; WILSON, C.L.;ADEYEYE, O.; KAMWE, M.K.; PUSEY, P.L.; CHALUTZ, E.;SULTANA, T.; DROBY, S. Aplication of ultraviolet-C light on storage rots and ripening of tomatoes. Journal of Food Protection, v.56, p. 831-892 1993.

LOPES, H.; SILVA, B.; NASCIMENTO, E.; RAMOS, L.; PEREIRA, M.; CARNEIRO, R. A cultura do morangueiro no Distrito Federal. Brasília-DF: EMATER, p. 76, 2005.

LORENZETTI, E. R. Controle de doenças do morangueiro com óleos essenciais e Trichoderma spp. 2012. 107 f. Tese (Doutorado em Fitopatologia) - Universidade Federal de Lavras, Lavras M G. 2012.

LUCENA, E. M. P. de. Desenvolvimento e maturidade fisiológica de manga "Tommy Atkins" no vale do São Francisco. 2006. 152 f. Tese (Doutorado em Agronomia) Universidade Federal do Ceará, Fortaleza, 2006.

MAAS, J. L. Compendium of Strawberry Diseases. American Phytopathological Society, St. Paul, 1984 MN.

MADAIL, J. C. M.; ANTUNES, L. E.; BELARMINO, L. C.; DA SILVA, B. A.; GARDIN, J.A. Avaliação econômica dos sistemas de produção de morango: Convencional, Integrado e Orgânico. ISSN 1806-9185. Pelotas, RS. 2007 
MADAIL, J.C.M.; ANTUNES, L.E.C.; REISSER, JUNIOR. C.; BELARMINO, L.C.; NEUTZLING, D.M.; SILVA, B.A. Economia da produção de morango: estudo de caso de transição para produção integrada. Boletim de Pesquisa e Desenvolvimento, v. 53, p.1-25. 2007.

MADDEN, L.V.; ELLIS, M.A.; GROVE, G.G.; REYNOLDS, K.M.; WILSON, L.L.; 1991. Epidemiology and control of leather rot of strawberries. Plant Diseases, v. 75, p. 39-445, 1991.

MARI, M.; LEONI, O.; LORI, R.; CEMBALI,T. Antifungal vapour-phase activity of allylisothiocyanate aganinst Penicillium expansum on pears. Plant Pathology, v. 51, p. 231-236, 2002.

MARQUENIE, D.; MICHIELS, C.W.; GEERAERD, A.H.; SCHENK,A.; SOONTJENS,C.;VAN IMPE, J.F.;NICOLAI, B.M. Using survival analysis to investigate the effect of UV-C and heat treatment on storage rot of strawberry and sweet cherry. International Journal of Food Microbiology, v.73. 2002.

MARQUES, R.P.; MONTEIRO, A.C.; PEREIRA, G.T. Crescimento, esporulação e viabilidade de fungos entomopatogênicos em meios contendo diferentes concentrações do óleo de Nim (Azadirachta indica). Ciência Rural, v.34, n.6, p.1675-1680. 2004.

MATTOS, M.L.T. Segurança Alimentar: $O$ caso do morango. In RASEIRA, M.ANTUNES,L; TREVISAN, R; DIAS,E.G. $2^{\circ}$ Simpósio Nacional do morango e $1^{\circ}$ Encontro de Pequenas Frutas e Frutas Nativas. Palestras Pelotas - RS: EMBRAPA 2004.

MAZOYER, M.; ROUDART, L. História das agriculturas no mundo: Do neolítico à crise contemporânea. p. 568, Editora UNESPI 2009.

METCALF e EDDY. Wastewater Engineering. 3ed. Treatment, disposal, reuse, Mc Graw Hill International Editions, 1991. 349 p.

MONTERO, T. M.; MOLLÁ, E. M.; ESTEBAN, R. M.; ANDRÉU, F. J. L. Quality attributes of strawberry during ripening. Scientia Horticulturae, v. 65, p. 239-250, 1996.

MORETTI, C.L. Manual de processamento mínimo de frutas e hortaliças. Brasília: Embrapa Frutas e Hortaliças e SEBRAE. 2007. 531p.

NASCIMENTO, M.S.; SILVA, N. Tratamentos químicos na sanitização de morango (Fragaria vesca L). Brazilian Journal of Food Technology, v. 13, p.11-17. 2010.

NEVES, M. C. P.; MEDEIROS, C. A. B.; ALMEIDA, D. L.; DE-POLLI, H.; RODRIGUES, H. R.; GUERRA, J. G. M.; NUNES, M. U. C.; CARDOSO, M. O.; AZEVEDO, M. S. F. R.; VIEIRA, R. C. M.; SAMINEZ, T. C. O. Agricultura Orgânica: Instrumento para a sustentabilidade dos sistemas de produção e valoração de produtos agropecuários. Seropédica: Embrapa Agrobiologia, 2000. 22 p. (Embrapa Agrobiologia. Documentos, 122).

NJUGUNA, W. Development and Use of Molecular Tools in Fragaria. 2010. 389 f. Tese (Doctor of Philosophy) - Oregon State University. 2010. 
NOVAK, J.; YUAN, J. The ozonation concept: Advantagens of ozone treatment and comercial developments. Advances in thermal and non-thermal food preservation. Edited by Gaurav Tewari and Vijay Juneja, p. 185-193, 2007.

OFFIT, P. A. J.; MOSER, C.A. The problem with Dr Bob's alternative vaccine schedule. Pediatrics, v. 123, p. 164-170, 2009.

OIVEIRA, A.; BONOW, S.; Novos desafios para o melhoramento genético da cultura do morangueiro no Brasil. Informe Agropecuário, Belo Horizonte, v.33. 2012.

OLIVEIRA, F. E. da R.; Qualidade de pêssegos Diamante (Prunus pérsica (L.) Batsch) submetidos ao 1- metilciclopropeno. 2005. 68 f. Dissertação (Mestrado em Agroquímica e Agrobioquímica) - Universidade Federal de Lavras, Lavras, MG. 2005.

OLIVEIRA, J.E.D.; MARCHINI, J. S. Ciências nutricionais. Sao Paulo: Sarvier, 1998. 403p.

OSHITA, D.; JARDIM, S.F.C.I. Morango: uma preocupação alimentar, ambiental e sanitária, monitorado por cromatografia líquida moderna, Scientia Chromatographica. v.4, n.1, p. 52$76,2012$.

PALOU, L. Penicillium digitatum, Penicillium italicum (Green Mold, Blue Mold). Postharvest Decay Control Strategies. 2014, 45-102p.

PARISH, M.; BEUCHAT, L.; SUSLOW. T.; HARRIS, L.; GARRET, E.; FARBER, J.; BUSTA; F. Methods to reduce or eliminate pathogens from fresh and fresh-cut produce. Comprehensive Reviews in Food Science and Food Safety, v.2. p.161-173. 2003.

PASSOS, F.A. Influência de sistemas de cultivo na cultura do morango (Fragaria ananassa Duch). 1998. 105 f. Tese (Doutorado em Agronomia) - Escola Superior de Agricultura "Luiz de Queiroz", Universidade de São Paulo, Piracicaba, SP. 1998.

PATEL, M. K.; CHEN, S.; PRINGLE, J.; RUSSO, E.; VIÑARAS, J.; WEISS, J. A prolonged outbreak of Salmonella Montevideo infections associated with multiple locations of a restaurant chain in Phoenix, Arizona, 2008. Journal of Food Protection, v. 73, n. 10, p.1858-1863, 2010.

PEREIRA, G. V. M.; MAGALHÃES, K. T.; MOREIRA, G. M.; PEREIRA, V. M.; SILVA, M. S.; SCHWAN, R. F. Diversidade fenotípica de bactérias presentes em frutos de morango Fragaria ananassa) orgânico. In: XIX Congresso de pós-graduação da Universidade Federal de Lavras. 2010, Lavras, Anais... Lavras, 2010.

PEREZ, A.; PLATTNER, K. Organic fruit and berries. Economic Research Service, USDA, p. 1-13, 2013

PINELI, L. L. O. Qualidade e potencial antioxidante in vitro de morangos in natura e submetidos a processamentos. 2009. 222 f. Tese (Doutorado em Ciências da Saúde)Faculdade de Ciências da Saúde, Universidade de Brasília, Brasília, DF. 2009.

PINELI, L. L.O.; MORETTI, C.L.; DOS SANTOS, M.S.; CAMPOS, A.B.; BRASILEIRO, A.V.; CÓRDOVA, A.C.; CHIARELLO, M.D.. Antioxidants and other chemical and physical 
characteristics of two strawberry cultivars at different ripeness stages. Journal of Food Composition and Analysis, v.24, p. 11-16, 2011.

PONCE, A.; BASTIANI, M.; MINIM, V.; VANETTI, M. Características físico-químicas e microbiológicas de morango minimamente processado. Ciência e Tecnologia de Alimentos. p.1-6, 2007.

PRESTES, E. B. Avaliação da eficiência do ozônio como sanitizante em hortaliças folhosas minimamente processadas. 2007. 135 f. Tese (Doutorado em Tecnologia de Alimentos) - Universidade Estadual de Campinas, Campinas. 2007.

REBOUÇAS, L. O. S.; GONÇALVES, A. A. Uso de ozônio em sistemas de depuração de ostras visando a segurança para o consumidor. Revisão Actapesca, v. 1, p. 79-90, 2013.

REIS, A.; COSTA, H. Principais doenças do morangueiro no Brasil e seu controle. EMBRAPA Circular Técnica 96. Brasília DF. 2011.9 p.

RICO, D.; MARTIN-DIANA, A.B.; BARAT, J.M.; BARRY-RYAN, C. Extending and mearuring the quality of fresh-cut and vegetables: a review. Trends in Food Science \& Technology. v.18, p. 1-15, 2007.

ROMANAZZI, G.; NIGRO, F.; IPPOLITO, A.; SALERNO, M. Effect of short hypobaric treatments on postharvest rots of sweet cherries, strawberries and table grapes. Postharvest Biology and Technology, v.22, p. 1-6, 2001.

RONQUE, E.R.V. A cultura do morangueiro. Curitiba: EMATER - PR, 1999. 206p.

ROSA, J. S.; GODOY, R. L. O.; NETO, J. O.; CAMPOS, R. S.; MATTA,V. M.; FREIRE, C. A.; SILVA, A. S.; SOUZA, R. S. Desenvolvimento de um método de análise de vitamina C em alimentos por cromatografia líquida de alta eficiência e exclusão iônica. Ciência e Tecnologia de Alimentos, v.27, n. 4, p. 837 - 846, 2007.

ROZADO, A.; FARONI, L.; URRUCHI, W.; GUEDER, R.; PAES, J. Aplicação de ozônio contra Sitophiluszeamaise Triboliumcastaneum em milho armazenado. Revista Brasileira de Engenharia Agrícola Ambiental, v. 12, p. 282-285, 2008.

SANHUEZA, R. M. V.; HOFFMAN, A.; ANTUNES, L. S. C.; FREIRE, J. M. Sistema de Produção de Morango para Mesa da Região da Serra Gaúcha e Encosta Superior do Nordeste. Importância da Cultura. Sistema de Produção. Versão Eletrônica. 2005. Disponível em: http://sistemasdeproducao.cnptia.embrapa.br. Acesso em: 10 de dezembro de 2013.

SANTOS, C.; COELHO, A.; CARREIRO, S. Avaliação microbiológica de polpas congeladas. Ciência e Tecnologia de Alimentos, v. 28, n.4, p. 913-915, 2008.

SAWYER, C.N.; MCCARTY, P.L.; L. PARKIN, PARKIN. G.F. Chemistry for Environmental Engineering. McGraw Hill, Inc., New York, NY. p. 93-98, 1994.

SCALZO, A. J.; POLITI, A.; PELlEGRINI, N. D. C.; BRUNO MEZZETTI, A.; MAURIZIO BATTINO. Plant genotype affects total antioxidant capacity and phenolic contents in fruit. Basic Nutrition Investigation, n. 21, p. 207-213, 2005. 
SCALZO, J.; MEZZETTI, B.; BATTINO, M. Total antioxidant evaluation: critical steps for assaying berry antioxidant features. Biofactors, v. 23, p. 221-227, 2005.

SCHLIMME, D. V. Marketing lightly processed fruits and vegetables. Horticulture Science, v. 30, n. 1, p. 15-17. 1995.

SCHULTZ G. Agroecologia, agricultura orgânica e institucionalização das relações com o mercado nas organizações de produtores do Sul do Brasil. Agrária, v. 7, p.61-93, 2007.

SEERAM, N.P.; LEE, R.; SCHEULLER, H.S.; HEBER, D. Identification of phenolic compounds in strawberries by liquid chromatographic analysis of phenolic compounds in strawberries by liquid chromatography electrospray ionization mass spectroscopy. Food Chemistry, v. 97, p.1-11, 2006.

SHAW, A. L.; SVOBODA, A.; JIE, B.; NONNECKE, G.; MENDONCA, A. Survival of Escherichia coli on strawberries grown under greenhouse conditions. Food Microbiology, v. 46, p. 200-203, 2015.

SHAW, A. L.; SVOBODA, A.; JIE, B.; NONNECKE, G. Survival of Escherichia coli on strawberries grown under greenhouse conditions. Food Microbiology, v. 46 , p. 200-203, 2014.

SHAW, D.V. Response to selection and associated changes in genetic variance for soluble solids and titratable acids contents in strawberries. Journal of the American Society for Horticultural Science, v. 115, n.5, p. 839-843, 1990.

SILVA, A.F.; DIAS, M.S.C.; MARO, L.A.C. Botânica e fisiologia do morangueiro. Belo Belo Horizonte: EPAMIG, Informe Agropecuário, v.28, n.236, p.7-13, jan./fev. 2007.

SILVA, F. L.; ESCRIBANO - BAILÓN, M.T.; ALONSO, J.J.; RIVAS-GONZALO, J.C.; SANTOS-BUELGA, C. Anthocyanin pigments in strawberry LWT. Food Sciense and Technology. v.40, p. 374-382, 2007.

SILVA, J.; SILVA, E. S.; SILVA, P. S. L. Determinação da qualidade e do teor de sólidos solúveis nas diferentes partes do fruto da pinheira (Annona squamosa L.) Comunicação Científica. Revista Brasileira de Fruticultura, v.24, n.2, p. 562-564. 2002.

SILVA, L. F. Fungos: um estudo de ocorrência nos alimentos. 2008. 35 f. Trabalho de conclusão de curso (Especialização em Microbiologia) - Universidade Federal de Minas Gerais, Belo Horizonte, MG. 2008.

SILVA, T. P. Características produtivas e físico-químicas de frutos de morangueiro orgânico cultivado com o uso de extrato de algas. 2011. $121 \mathrm{f}$. Dissertação (Mestrado em Agronomia) - Universidade Federal de Paraná, Curitiba, PR. 2011.

SILVEIRA, A.C.; CONESA, A.; AGUAYO, E.; ARTES. F. Alternative Sanitizers to Chlorine for Use on Fresh-Cut "Galia" (Cucumismelovar. catalupensis) Melon. Journal of Food Science, v.73, n.9, p. 1146-1151, 2008. 
SILVEIRA, C.; Cloro e ozônio aplicados á desinfecção de efluente hospitalar tratado em contadores biológicos rotatórios com avaliação de efeitos tóxicos em Daphniasimilis. Porto Alegre, 2004.

SIQUEIRA, R. S.; BORGES, M. F. Microbiologia de frutas e produtos derivados. In: TORREZAN, R. (Coord.). Curso de processamento de frutas. Rio de Janeiro: EMBRAPA/CTAA, 1997. p. 2-13.

SMIRNOFF, N. The Function and Metabolism of Ascorbic Acid in Plants. Botanical Briefing. Annals of Botany, v.78, p. 661-669, 1996.

SNOWDON, A.L. A color atlas of post-harvest diseases and disorders of fruits and vegetables. Vol. 1. General introduction and fruits. CRC Press, Boca Raton, FL. 1990. 302 p.

SOMMER, N.F., FORTLAGE, R.J., EDWARDS, D.C. Postharvest diseases of selected commodities. In: ADEL, K. (Ed.). Postharvest Technology of Horticultural Crops. University of California, 1994 p. 117-160.

SOPHER, C. D.; GRAHAM, D. M.; RICE, R. G.; STRASSER, J.H. Studies on the Use of Ozone in Production Agriculture and Food Processing. Proceedings of the International Ozone Association. Pan American Group. 2002, p.15.

SREENIVASAPRASAD, S.; TALHINHAS, P. Genotypic and phenotypic diversity in Colletotrichum acutatum, a cosmopolitan pathogen causing anthracnose on a wide range of hosts. Molecular Plant Pathology - v. 6., p. 361-378, 2005.

STAUDT, G. Strawberry Biogeography, Genetics and Systematics. Proceeding of the 6th International Strawberry Symposium, v. 842, p.71-84, 2009.

STAUDT, G. Taxonomic studies in the genus Fragaria; typification of the Fragariaspecies known at the time of Linnaeus. Canadian Journal of Botany, v.40, p.869-886, 1962.

STONE, C.; Oregon Health Authority, Fresh strawberries implicated in E. coli O157 Outbreak in NW Oregon 2011. New York Berry News, v. 10, n. 7, p. 29, 2011.

TANIWAKI, M. H.; SILVA, N. Fungos em alimentos - ocorrência e detecção. Campinas, 82 p., 2001.

TÖFOLI, J.G.; FERRARI, J.T.; DOMINGUES, R.J. Botrytis sp. em espécies hortícolas: hospedeiros, sintomas e manejo. Biológico, São Paulo, v.73, n.1, p.11-20, 2011.

TOLEDO, M., Guia para a Produção de Morango de Honduras. Fundação Hondureña de Pesquisa Agrícola (FHIA). A Esperança, Intibucá, Honduras, C. A. 2003. 36 p.

TORREZAN, R.; UBOLDI EIROA, M. N.; PFENNING. L. Identificação de microrganismos isolados em frutas, polpas e ambiente industrial. Boletim do Centro de Pesquisa de Processamento de Alimentos (CEPPA), Curitiba, v. 18, n. 1, p. 2738, jan./jun.2000.

TULIPANI, S.; MEZZETTI, B.; CAPOCASA, F.; BOMPADRE, S.; BEEKWILDER, R. V.; CAPANOGLU, E.; BOVY, A.; BATTINO, M. Antioxidants, phenolic compounds, and 
nutritional quality of different strawberry genotypes. Journal of Agricultural and Food Chemistry, v.56, p. 696-704, 2008.

USDA - US Department of Agriculture, Agriculture Research Service. USDA national nutrient for standard references, release 23. Fruits and fruit juices; 2010

VANETTI, M.C.D. Microbiologia. In: MORETTI. C.L. Manual de processamento mínimo de frutas e hortaliças. Brasília: Embrapa Frutas e Hortaliças e SEBRAE 2007.

WANG, H.G. ; CAO, R.L. Prior Total antioxidant capacity of fruits. Journal Agriculture Food Chemistry, v.44, p. 70, 1996.

WANG, S. Y.; LIN, H. S. Antioxidant activity in fruits and leaves of blackberry, raspberry, and strawberry varies with cultivar and developmental stage. Journal of Agriculture Food Chemistry, v. 48, p. 140-146, 2000.

WILEY,R.C.(Ed). Frutas y hortalizas minimamente procesadas y refrigeradas. Madrid: Acribia, 1997. 362p.

YANG, X.; WANG, H. Escherichia coli - Pathogenic E. coli. Encyclopedia of Food Microbiology, p. 695-701, 2014.

YU, K., NEWMAN, M.C., ARCHBOLD, D.D., HAMILTON-KEMP, T.R. Survival of Escherichia coli O157:H7 on strawberry fruit and reduction of the pathogen population by chemical agents. Journal of Food Protection, v.64, p. 1334-1340, 2001.

ZAMBOLIM, L.; COSTA, H. Manejo Integrado de Doenças do Morangueiro. In: Boletim do Morango: Cultivo Convencional, Segurança Alimentar e Cultivo Orgânico. Belo Horizonte. 2006. 55p.

ZHANG, H.;, LONGCHUAN, M.; TURNER, M.; XU, H.; ZHENG, X.; DONG, Y.; JIANG, S. Salicylic acid enhances biocontrol efficacy of Rhodotorula glutinis against postharvest Rhizopus rot of strawberries and the possible mechanisms involved. Food Chemistry, v.122, p. 577-583, 2010.

ZHAO, Y. Berry Fruit: Value - Added Products for Health Promotion. 2007. 168 p. 
CAPÍTULO I

OZONIZAÇÃO COMO MÉTODO ALTERNATIVO NO CONTROLE DE MICRORGANISMOS EM MORANGOS PRODUZIDOS EM SISTEMA ORGÂNICO 


\section{OZONIZAÇÃO COMO MÉTODO ALTERNATIVO NO CONTROLE DE MICRORGANISMOS EM MORANGOS PRODUZIDOS EM SISTEMA ORGÂNICO}

\section{RESUMO}

Uma alternativa que vem sendo estudada como agente antimicrobiano em produtos de origem vegetal e animal é o gás ozônio, que possui alto potencial oxidativo, o que o torna eficiente no controle dos diversos grupos de microrganismos. Diante do exposto, objetivou-se com este trabalho avaliar o efeito do ozônio aplicado em morango produzido em sistema orgânico sobre microrganismos, adotando-se diferentes combinações de concentração e período de exposição ao gás. Foram utilizados morangos orgânicos da variedade "Festival”. Os morangos foram divididos em cinco lotes correspondendo aos tratamentos: morangos não ozonizados controle; morangos ozonizados na concentração de 1000 ppm durante 30 min; morangos ozonizados na concentração de 1000 ppm durante $60 \mathrm{~min}$; morangos ozonizados na concentração de 2000 ppm durante 30 min; morangos ozonizados na concentração de 2000 ppm durante $60 \mathrm{~min}$. Após a ozonização, os frutos foram armazenados em câmara fria a $5{ }^{\circ} \mathrm{C}$ por 12 dias. As análises microbiológicas dos frutos foram realizadas no dia da ozonização (tempo zero) e a cada três dias de armazenamento. Foi avaliada a pequisa de Salmonella spp. e as análises de Número Mais Provável de coliformes a $35^{\circ} \mathrm{C}$ e coliformes termotolerantes, Contagem de bolores e leveduras e contagem de bactérias mesofilicas aeróbias. Adotou-se Delineamento Inteiramente Casualizado em esquema fatorial $5 \mathrm{X} 5$, sendo cinco tratamentos e cinco períodos de armazenamento (0, 3, 6, 9 e 12 dias), com quatro repetições. Inicialmente realizou-se análise de variância e posteriormente teste de Tukey a 5\% de probabilidade. Em função da ausência de Salmonella spp., coliformes termotolerantes e da inexpressiva contagem de coliformes totais com valores no tempo zero no controle $2,32 \mathrm{NMP} \mathrm{g}^{-1}$ e 2000 ppm por 30 min $0,1 \mathrm{NMP}^{-1}$, não foi possível avaliar o efeito da ozonização sobre esses grupos de microrganismos. Com relação à contagem de bolores e leveduras, não houve variação significativa em função da ozonização, sendo que a máxima redução foi de 0,82 ciclo log, nos frutos ozonizados na concentração de $2.000 \mathrm{ppm}$ por $60 \mathrm{~min}$. Verificou-se, no início do armazenamento que a contagem de mesófilos aeróbios nos frutos ozonizados nas concentrações de 1.000 e 2.000 ppm, por 60 min foi inferior a contagem obtida nos frutos não ozonizados. Outra tendência observada foi a redução significativa na contagem de bactérias mesofílicas aeróbias no terceiro dia de armazenamento nos frutos ozonizados nas concentrações de 1.000 ppm, por $60 \mathrm{~min}$, e 2.000 ppm, por 30 e $60 \mathrm{~min}$. Concluiu-se, a partir 
dos resultados obtidos, que a ozonização é um método promissor, no que tange o controle de microrganismos em morangos produzidos em sistema orgânico.

Palavras-chave: Ozonização, controle microbiano, armazenamento. 


\section{OZONATION AS ALTERNATIVE METHOD OF MICRORGANISMS CONTROL IN STRAWBERRIES PRODUCED IN ORGANIC SYSTEM}

\section{ABSTRACT}

An alternative that has been studied as an antimicrobial agent in plant and animal products is ozone gas, which has high oxidative potential, which makes it effective in controlling various groups of microorganisms. Considering this, the aim of this research is to evaluate the effect of ozone applied in strawberry produced in organic system on microorganisms, adopting different combinations of concentration and gas exposure period. Organic strawberries variety called Festival were used. The strawberries were divided into five lots corresponding to the treatments: not ozonated strawberries - control; strawberries ozonized at 1,000 ppm for 30 min; strawberries ozonized at 1,000 ppm for $60 \mathrm{~min}$; strawberries ozonized at a concentration of 2,000 ppm for $30 \mathrm{~min}$; strawberries ozonized at a concentration of 2,000 ppm for $60 \mathrm{~min}$. After ozonation, the fruits were stored in cold storage at $5^{\circ} \mathrm{C}$ for 12 days. The microbiological analysis of fruits were held on the ozonation (time zero) and every three days of storage.The presence of Salmonella spp were evaluated and quantified total coliforms and fecal coliforms, molds and yeasts and mesophilic aerobic. Completely randomized design in factorial $5 \times 5$ was adopted, with five treatments and five storage periods $(0,3,6,9$ and 12 days), with four replications. Initially it was performed analysis of variance and subsequently Tukey test at 5\% probability. Due to the absence of Salmonella spp. and inexpressive total coliform count and coliform was not possible to assess the effect of ozonation on these groups of microorganisms in the strawberries. Concerning to yeasts and molds, there was no significant variation in the function of ozonation, and the maximum reduction was $0.82 \log$ cycle, fruits ozonized at a concentration of 2,000 ppm for $60 \mathrm{~min}$. In the beginning of storage it has been found the mesophilic aerobic count fruit ozonized at concentrations of 1,000 and 2,000 ppm for $60 \mathrm{~min}$, less than the count obtained ozonized no fruit. Another trend observed was a significant reduction in the mesophilic aerobic count in the third storage day in fruit ozonized at concentrations of $1,000 \mathrm{ppm}$ for $60 \mathrm{~min}$, and 2,000 ppm for 30 and $60 \mathrm{~min}$. The research concluded that ozonation is a promising method, regarding the control of microorganisms in strawberries produced in an organic system.

Keywords: ozonation, microbial control, storage. 


\section{INTRODUÇÃO}

Os frutos do morangueiro são atrativos para o consumidor, por apresentar características próprias, tais como: cor, o brilho, sabor, textura e odor (HENRIQUES et al., 2004). Os frutos também se destacam por serem importantes fontes de compostos bioativos, tais como vitamina C, folato e compostos fenólicos (FRANCO, 2002; PROTEGGENTE et al., 2002; GIAMPIERI et al., 2012). Outras vitaminas também são encontradas no morango, tais como tiamina, riboflavina, niacina, vitamina B6, vitamina $\mathrm{K}$, vitamina A e vitamina $\mathrm{E}$. Destaca-se que os compostos bioativos encontrados no morango estão associados a propriedades, tais como ação antioxidante, capacidade de reduzir a suscetibilidade a infecções, efeito diurético e atividade anti-inflamatória em reumatismo e gota (ROCHA et al., 2008).

O morango é consumido predominantemente in-natura, mas uma considerável quantidade é utilizada na indústria, para produção de geléias e sucos, (SEERAM et al, 2006; CALVETE et al, 2008). Dessa forma, deve-se garantir adequado manejo durante o cultivo, colheita, transporte e armazenamento, com intuito de reduzir perdas e alcançar melhor aceitação pelo consumidor (ZAMBOLIM; COSTA 2005; HENZ et al., 2008). Durante todas as etapas da cadeia produtiva, devem ser conservadas as propriedades físico-químicas do produto, tais como $\mathrm{pH}$, acidez total titulável, coloração e sólidos solúveis, além de controlado e/ou inibido o desenvolvimento de microrganismos patogênicos e deteriorantes, que comprometem a sanidade do produto. Ressalta-se que a vida de prateleira do morango é limitada, entre 5 e 7 dias, devido especialmente à alta atividade microbiana e respiratória (AGUAYO et al., 2006; NASCIMENTO e SILVA, 2010). Outro aspecto relevante, é que o morango esteve associado a surtos de hepatite A, além de contaminação por Norovírus, Cyclospora cayatanensis e Staphylococcus aureus (NOTERMANS et al., 2004; SIVAPALASINGAM et al., 2004).

Diante do exposto, faz-se necessária a adoção de métodos que sejam eficientes na redução de microrganismos, tanto patogênicos como deteriorantes, de tal forma a garantir a segurança do produto e, consequentemente, reduzir a velocidade do processo de deterioração. De acordo com BEUCHAT et al. (1998), é possível redução de até 90\% da carga microbiana, adotando-se lavagem com água corrente, porém não é suficiente para tornar o alimento seguro. Em função disso, é fundamental a etapa de sanificação, com a utilização de agentes que sejam eficientes na inativação dos microrganismos. Dentre as propriedades desejadas para 
um sanificante, destacam-se: possuir largo espectro antimicrobiano; ser de fácil uso; não possuir propriedades tóxicas e irritantes; ser de baixo custo (LELIEVELD et al., 2003).

Atualmente o cloro e derivados são muito utilizados na higienização das verduras e frutas, sendo aceito pela legislação brasileira. No entanto, segundo Nascimento e Silva (2010), com o uso do cloro, há risco de formação de compostos indesejáveis, como os trihalometanos, originados pela reação com matéria orgânica e que são considerados potenciais carcinógenos. Ainda de acordo com esses autores, em alguns países da Europa, como Alemanha, Holanda, Dinamarca, Suíça e Bélgica, o uso de cloro em alimentos frescos é proibido. Em vista disso, é essencial o estudo de alternativas ao cloro, que sejam eficientes na inativação de microrganismos e não representem risco aos consumidores. Uma alternativa que vem sendo estudada como agente antimicrobiano em produtos de origem vegetal e animal é o gás ozônio.

O gás ozônio $\left(\mathrm{O}_{3}\right)$, ou oxigênio triatômico, é uma forma alotrópica do oxigênio, que pode ser produzida naturalmente como resultado de relâmpagos ou radiação ultravioleta (KIM et al., 1999). Salienta-se que o ozônio foi classificado como GRAS (Generally Recognized as Safe) nos Estados Unidos e liberado como agente antimicrobiano pelo FDA (Food and Drug Administration) para uso em alimentos, tanto na forma gasosa quanto dissolvido em água (FDA, 2001). Dentre os compostos encontrados na natureza, o gás ozônio se destaca por apresentar o segundo maior potencial de oxidação (2,07 mV) (MUSTAFA, 1990; GUZELSEYDIM et al., 2004). Essa característica torna o ozônio um forte agente antimicrobiano com grande aplicabilidade na indústria de alimentos e um dos mais potentes sanitizantes conhecidos.

Já é conhecido o efeito do ozônio sobres diversos grupos de microrganismos, tais como os fungos dos gêneros Aspergillus, Fusarium, Geotrichum, Myrothecium, Alternaria, Penicillium, Botrytis e Mucor (RAILA et al., 2006; WU et al., 2006; ZOTTI et al., 2009; ALENCAR et al., 2013), além do vírus, e bactérias (KIM et al., 1999; KHADRE et al., 2001; OSKAN et al., 2011; AGUIRRE; CÁNOVAS, 2013; ALEXOPOULOS et a., 2013). Dentre as espécies de bactérias patogênicas que apresentaram sensibilidade ao gás ozônio, tem-se Listeria monocytogenes, Escherichia coli 0157:H7, Bacillus cereus e Samonella spp. (STEENSTRUP; FLOROS, 2004; AKBAS et al., 2008; PATIL et al., 2010; TORLAK et al., 2013). 
Com relação à aplicação do ozônio em alimentos produzidos em sistema orgânico no Brasil, é importante salientar que a legislação nacional permite o uso de atmosfera modificada com gás nitrogênio ou dióxido de carbono como método de conservação (BRASIL, 2014). Dessa forma, o gás ozônio pode ser uma alternativa para atmosfera modificada em alimentos obtidos em sistema orgânico. O gás pode ser gerado no próprio local de aplicação e o produto de sua degradação é um composto não tóxico, o oxigênio. Então, faz-necessária à obtenção de dados que comprovem a eficácia do ozônio no controle de microrganismos em alimentos orgânicos, de tal forma a subsidiar a inclusão dessa técnica dentre as permitidas.

Diante do exposto, objetivou-se com este trabalho avaliar o efeito do ozônio aplicado em morango produzido em sistema orgânico sobre microrganismos deteriorantes e patogênicos, adotando-se diferentes combinações de concentração e período de exposição ao gás. 


\section{MATERIAL E MÉTODOS}

O experimento foi conduzido no Laboratório de Pré-Processamento e Armazenamento de Produtos de Vegetais e no Laboratório de Microbiologia de Alimentos (LAMAL), localizados na Faculdade de Agronomia e Medicina Veterinária, na Universidade de Brasília, UnB, no Distrito Federal.

\subsection{Obtenção dos morangos}

Os morangos (Fragaria ananassa Duch) da variedade "Festival" foram adquiridos diretamente de um produtor orgânico da região administrativa de Brazlândia no Distrito Federal, no dia 27/05/2014. Os frutos foram coletados pela tarde no estado de maturação comercial (3/4 maturação), depois foram transportados para o Laboratório de PréProcessamento e Armazenamento de Produtos Vegetais, colocados sobre refrigeração, a $5^{\circ} \mathrm{C}$ por um período de aproximadamente 12 horas. No dia seguinte, os morangos foram devidamente selecionados, aqueles que apresentaram ferimentos ou lesões foram descartados e somente os frutos uniformes, sadios, sem defeitos foram submetidos ao processo de ozonização.

\subsection{Geração do ozônio e determinação da concentração do gás}

Para a geração do ozônio foi utilizado o gerador de ozônio, (Modelo O\&L 3.0-O2 $\mathrm{RM})$. O equipamento funciona entre dois eletrodos paralelos, entre eles existe um dielétrico, e um espaço livre por onde percorre o ar seco. Neste espaço é produzida uma descarga em forma de filamentos, constituída por elétrons com energia suficiente para ocasionar a quebra das moléculas de oxigênio, formando o ozônio $\left(\mathrm{O}_{3}\right)$. Neste processo de geração do ozônio, a matéria prima é o oxigênio $\left(\mathrm{O}_{2}\right)$, obtido do concentrador de oxigênio que se acopla ao gerador. A vazão adotada para a geração do ozônio foi de $2,0 \mathrm{~L} \mathrm{~min}^{-1}$, na temperatura de 25 ${ }^{\circ} \mathrm{C}$.

A quantificação da concentração inicial de ozônio foi determinada pelo método iodométrico, através da titulação indireta (CLESCERI, 2000). Esse método consiste no borbulhamento do ozônio residual durante 1 minuto, em $50 \mathrm{~mL}$ de solução de iodeto de potássio $(\mathrm{KI}) 1 \mathrm{~N}$, liberando iodo $\left(\mathrm{I}_{2}\right)$; adicionando $2,5 \mathrm{~mL}$ de ácido sulfúrico $1 \mathrm{~N}\left(\mathrm{H}_{2} \mathrm{SO}_{4}\right)$ 
0,01 N, reduzindo assim, o pH. Em seguida, é necessária a realização da titulação com tiossulfato de sódio $\left(\mathrm{Na}_{2} \mathrm{~S}_{2} \mathrm{O}_{3}\right)$ 0,1 M, até que a coloração amarela do iodo se torne clara de forma imediata. Por fim, foi adicionando amido $1 \%$, até o desaparecimento da coloração azul.

\subsection{Ozonização dos morangos}

Para a seleção dos tratamentos foi realizado um teste com diferentes doses e tempos de ozonização em morangos. Os frutos, devidamente selecionados, foram divididos em cinco lotes correspondendo aos tratamentos:

- Morangos não ozonizados - tratamento controle;

- Morangos ozonizados na concentração de 1000 ppm durante 30 minutos;

- Morangos ozonizados na concentração de 1000 ppm durante 60 minutos;

- Morangos ozonizados na concentração de 2000 ppm durante 30 minutos;

- Morangos ozonizados na concentração de 2000 ppm durante 60 minutos.

Os frutos foram colocados em recipientes de vidro com capacidade de $3,0 \mathrm{~L}$ de volume e submetidos ao processo de ozonização, com quatro repetições cada tratamento. Após a ozonização, os frutos foram colocados em embalagens de polietileno retangulares (12 $\mathrm{cm} \times 18 \mathrm{~cm}$ ), transparentes e com a devida identificação, sendo colocados 10 frutos por embalagem, correspondendo a aproximadamente $100 \mathrm{~g}$. Posteriormente, as embalagens contendo os frutos foram armazenadas aleatoriamente em uma câmara fria a $5{ }^{\circ} \mathrm{C}$. As análises microbiológicas dos frutos foram realizadas no dia da ozonização (tempo zero) e a cada três dias até 12 dias de armazenamento.

\subsection{Análises microbiológicas dos morangos submetidos ou não a ozonização}

\subsubsection{Recepção e preparo das amostras}

A metodologia utilizada na recepção e o preparo das amostras foi de acordo com Silva et al., ( 2001): Em um ambiente devidamente esterilizado as embalagens contendo $50 \mathrm{~g}$ de morango foram desinfetadas com álcool $70 \%$, depois a embalagem foi aberta para a retirada asséptica de $25 \mathrm{~g}$ de amostra coletadas em diferentes partes do fruto e colocadas em sacos plásticos devidamente identificados e mantidos em congelamento. 
As análises microbiológicas foram avaliadas segundo a metodologia oficial do Ministério de Agricultura Pecuária e Abastecimento - MAPA (BRASIL, 2003).

\subsubsection{Preparo das diliuçoes seriadas das amostras de morango}

Inicialmente $25 \mathrm{~g}$ de morangos foram diluídos em $225 \mathrm{~mL}$ de água peptonada a $0,1 \%$ $(\mathrm{p} / \mathrm{v})$ devidamente esterilizada, a fim de obter diluições seriadas para a realização destas análises. A homogenização foi realizada em homogenizador estomacher durante 2 minutos sendo esta a diluição $10^{-1}$ e a partir desta diluição foram feitas as diluições $10^{-2}$ e $10^{-3}$, para a inoculação nos diferentes meios de cultura, para a contagem de coliformes, Salmonella spp., bolores e leveduras e mesófilos aeróbios, conforme protocolo descrito pela Instrução Normativa número 62, do Ministério da Agricultura.

\subsubsection{Análise de Número Mais Provável de coliformes termotolerantes e coliformes a $35^{\circ} \mathrm{C}$}

Os coliformes foram quantificados usando a técnica de números mais prováveis (NPM), que baseia-se em duas fases:

Teste presuntivo: após a homogeneização inoculou-se a amostra padrão em três diluições decimais sucessivas $\left(10^{-1}, 10^{-2}\right.$ e $\left.10^{-3}\right)$, dentro de cada tubo de ensaio, que continha $10 \mathrm{~mL}$ de caldo lauril sulfato triptose CLST (Acumedia) e tubos indicadores de fermentação invertidos (Durham). Após a semeadura, os tubos foram colocados em estufa bacteriológica tipo BOD (Quimis) a $35^{\circ} \mathrm{C}$ durante 48 horas de incubação. Consideraram-se tubos positivos aqueles que apresentaram turvação e formação de gás.

Teste confirmativo coliformes totais: a partir dos tubos positivos de CLST obtido na fase presuntiva foi transferido $1 \mathrm{ml}$ para tubos de ensaio que continham o caldo verde brilhante (Acumedia) com tubos Durham invertidos, Em seguida, os tubos foram colocados em estufa tipo BOD a $35^{\circ} \mathrm{C}$ para coliformes totais

Teste confirmativo coliformes termotolerantes: dos mesmos tubos positivos de CLST obtidos no teste presuntivo foi transferida uma aliquaota para o caldo Escherichia coli (EC) (Acumedia) com tubos Durham invertidos, para a quantificação de coliformes termotolerantes, respectivamente. Em seguida, os tubos foram colocados em estufa 
bacteriológica a $45{ }^{\circ} \mathrm{C}$ (DE LEO) para Escherichia coli (EC) por 24 - 48 horas. Os resultados foram expressos em NMP $\mathrm{g}^{-1}$, segundo o protocolo descrito na Instrução Normativa número 62 de 2003 (BRASIL, 2003).

\subsubsection{Pesquisa de Salmonella spp.}

O pré-cultivo usado como amostra padrão dos coliformes, foi aproveitado e incubado por 24 horas em estufa bacteriológica a $35^{\circ} \mathrm{C}$, sendo transferidas alíquotas de $1 \mathrm{~mL}$ para tubos que continham $10 \mathrm{~mL}$ de caldo selenito cistina (Fluka Analytical) e $1 \mathrm{ml}$ para tubos de ensaio contendo $10 \mathrm{~mL}$ de caldo Rapaport - Vassiliadi (Acumedia), os quais foram incubados numa estufa a $35{ }^{\circ} \mathrm{C}$, durante 24 horas, para o enriquecimento seletivo. A etapa seguinte foi o plaqueamento diferencial, baseada nos tubos de enriquecimento seletivo, que com o auxílio de alçadas para cada meio foram repicadas em placas contendo Agar Salmonela Shigella (Acumedia) e depois as placas foram colocadas de forma invertida em estufa bacteriológica a $35^{\circ} \mathrm{C}$, durante 24 horas para confirmar a presença da bactéria. As placas nas quais se suspeitava conter Salmonella spp. foram selecionadas para as provas bioquímicas em ágar tríplice açúcar ferro (TSI), ágar lisina ferro (LIA) e caldo ureia, seguindo o protocolo descrito IN62 - 2003 (BRASIL, 2003) e os parâmetros RDC 12 (BRASIL, 2001).

\subsubsection{Contagem de bolores e leveduras}

Para contagem de bolores e leveduras foi utilizado o método de plaqueamento direto, em superfície das diluições $10^{-1}$ e $10^{-2}$. Em meio asséptico, alíquotas de $1 \mathrm{~mL}$ do inóculo inicial das diferentes diluições foram colocadas em placas petri, acrescidas de $0,2 \mathrm{mg} \mathrm{mL}-1 \mathrm{de}$ acido tartárico. Em seguida, colocou-se aproximadamente $10 \mathrm{~mL}$ do Ágar Batata Dextrose (BDA), previamente fundido e mantido a $45{ }^{\circ} \mathrm{C}$. As placas foram cuidadosamente homogeneizadas e incubadas a $25^{\circ} \mathrm{C}$ por um período de 4 a 5 dias. Então, foram quantificadas as colônias presentes na placa. Os resultados foram expressos pelo número de Unidades Formadoras de Colônia por grama de produto (UFC $\mathrm{g}^{-1}$ ) e posteriormente em log UFC $\mathrm{g}^{-1}$ (BRASIL, 2003). 


\subsubsection{Contagem de bactérias Mesofílicas Aeróbias.}

Foi empregada a metodologia da Contagem Total de Mesófilos Aeróbios. Para isso, foram utilizadas alíquotas de $1 \mathrm{~mL}$ do inóculo inicial das diluições a $10^{-1}$ e $10^{-2}$ em placas petri, sendo adicionado aproximadamente $10 \mathrm{~mL}$ de meio Plate Count Agar. Após a solidificação, as placas invertidas foram colocadas a $35{ }^{\circ} \mathrm{C}$, por $48 \mathrm{~h}$. A quantificação foi inicialmente expressa em Unidades Formadoras de Colônia por grama de produto (UFC g ${ }^{-1}$ ) e posteriormente em $\log \mathrm{UFC} \mathrm{g}^{-1}$, segundo a IN 62 - 2003 (BRASIL, 2003).

\subsection{Delineamento Experimental}

Adotou-se Delineamento Inteiramente Casualizado em esquema fatorial 5X5, sendo cinco tratamentos e cinco períodos de armazenamento (0, 3, 6, 9 e 12 dias), com quatro repetições. Inicialmente realizou-se análise de variância e posteriormente teste de Tukey a 5\% de probabilidade, utilizando o software Statystics Analysis Systems (SAS). 


\section{RESULTADOS E DISCUSSAO}

Apresentam-se, na Tabela 1, os resultados referentes à detecção de Samonella spp. e à quantificação de coliformes totais e coliformes termotolerantes em morangos submetidos a ozonização em diferentes combinações de concentração do gás e período de exposição e armazenados a $5{ }^{\circ} \mathrm{C}$. Com relação a Samonella spp., não foram detectados em nenhuma amostra de morango, independentemente da ozonização e do período de armazenamento. Resultado semelhante foi observado para os coliformes termotolerantes. No que tange aos coliformes totais, foram quantificados somente no dia zero do armazenamento no tratamento controle que apresentaram contagens superiores a $<0,3$ germes $\mathrm{g}^{-1}$ equivalentes a 2,32 NMP germes $\mathrm{g}^{-1}$.

Tabela 1 - Média da contagem de Salmonella spp., Coliformes totais e Coliformes termotolerantes em morangos ozonizados em diferentes combinações de concentração do gás (ppm) e período de exposição (min) e armazenados a $5^{\circ} \mathrm{C}$

\begin{tabular}{|c|c|c|c|c|c|c|}
\hline \multirow{2}{*}{ Tratamento } & \multirow{2}{*}{ Parâmetros } & \multicolumn{5}{|c|}{ Período de Armazenamento (dias) } \\
\hline & & 0 & 3 & 6 & 9 & 12 \\
\hline \multirow{3}{*}{ Controle } & Salmonella spp. (ausência/presença) & - & - & - & - & - \\
\hline & C. Totais (NMP germes $\mathrm{g}^{-1}$ ) & 2,32 & - & - & - & - \\
\hline & C. Termotolerantes (NMP germes $\mathrm{g}^{-1}$ ) & - & - & - & - & - \\
\hline \multirow{3}{*}{$1.000 \mathrm{ppm} / 30 \mathrm{~min}$} & Salmonella spp. (ausência/ presença) & - & - & - & - & - \\
\hline & C. Totais (NMP germes $\mathrm{g}^{-1}$ ) & - & - & - & - & - \\
\hline & C. Termotolerantes (NMP germes $\mathrm{g}^{-1}$ ) & - & - & - & - & - \\
\hline \multirow{3}{*}{$1.000 \mathrm{ppm} / 60 \mathrm{~min}$} & Salmonella spp. (ausência/ presença) & - & - & - & - & - \\
\hline & C. Totais (NMP germes $\mathrm{g}^{-1}$ ) & - & - & - & - & - \\
\hline & C. Termotolerantes (NMP germes $\mathrm{g}^{-1}$ ) & - & - & - & - & - \\
\hline \multirow{4}{*}{$2.000 \mathrm{ppm} / 30 \mathrm{~min}$} & & - & - & - & - & - \\
\hline & Salmonella spp. (ausência/ presença) & - & - & - & - & - \\
\hline & C. Totais (NMP germes $\mathrm{g}^{-1}$ ) & 0,1 & - & - & - & - \\
\hline & C. Termotolerantes (NMP germes $\mathrm{g}^{-1}$ ) & - & - & - & - & - \\
\hline \multirow{3}{*}{$2.000 \mathrm{ppm} / 60 \mathrm{~min}$} & Salmonella spp. (ausência/ presença) & - & - & - & - & - \\
\hline & C. Totais (NMP germes $/ \mathrm{g}^{-1}$ ) & - & - & - & - & - \\
\hline & C. Termotolerantes (NMP germes $/ \mathrm{g}^{-1}$ ) & - & - & - & - & - \\
\hline
\end{tabular}

$\mathrm{NPM} \mathrm{g}^{-1}=$ Número mais provável por grama em escala logarítmica; - = ausência 
Em função da ausência de Salmonella spp. e da inexpressiva contagem de coliformes totais e de coliformes termotolerantes, não foi possível avaliar o efeito da ozonização sobre esses grupos de microrganismos nos morangos produzidos em sistema orgânico. É importante ressaltar que de acordo com o Regulamento Técnico sobre Padrões Microbiológicos para Alimentos, no caso de morangos frescos e similares, "in natura", inteiros, selecionados ou não, é exigido ausência de Salmonella spp. e a tolerância máxima de coliformes $45^{\circ} \mathrm{C}$ é equivalente a $2 \times 10^{3} \mathrm{NMP} \mathrm{g}^{-1}$ (BRASIL, 2011).

Encontram-se, na Tabela 2, os valores médios referentes à contagem de bolores e leveduras ( $\log$ UFC $\mathrm{g}^{-1}$ ) em morangos submetidos a diferentes combinações de período de exposição (min) e concentração do gás (ppm), independentemente do período de armazenamento. Apesar de ter ocorrido redução na contagem de bolores e leveduras nos frutos ozonizados, em comparação com o tratamento controle (frutos não ozonizados), essa alteração não foi significativa, de acordo com o teste de Tukey, a 5\% de probabilidade. A máxima redução obtida foi de 0,82 ciclo log, nos frutos ozonizados na concentração de 2.000 ppm, por 60 minutos. Não houve variação significativa na contagem de bolores e leveduras nos morangos, em decorrência da interação entre tratamento e período de armazenamento ( $p>0,05)$. Entretanto, verificou-se variação significativa na contagem de bolores e leveduras, quando se analisou o efeito do tratamento e do período de armazenamento, separadamente $(\mathrm{p}<0,05)$.

Tabela 2 - Valores médios referentes contagem de bolores e leveduras (log UFC g ${ }^{-1}$ ) em morangos submetidos a diferentes combinações de concentração do gás (ppm) e período de exposição (min)

Tratamento

Controle $\quad 1.000 \mathrm{ppm} / 30 \mathrm{~min} \quad 1.000 \mathrm{ppm} / 60 \mathrm{~min} \quad 2.000 \mathrm{ppm} / 30 \mathrm{~min} \quad 2.000 \mathrm{ppm} / 60 \mathrm{~min}$

$\begin{array}{lllll}3,52 \mathrm{a} & 3,15 \mathrm{a} & 2,76 \mathrm{a} & 3,11 \mathrm{a} & 2,70 \mathrm{a}\end{array}$

Médias seguidas de mesma letra não diferem estatisticamente entre si, pelo Tukey a 5\% de probabilidade.

Na Tabela 3 são apresentados os valores médios referentes à contagem de bolores e leveduras ( $\log$ UFC $\mathrm{g}^{-1}$ ) em morangos durante o período de armazenamento, independentemente da exposição ao gás ozônio. O comportamento observado está de acordo 
com o esperado, ou seja, houve aumento na contagem de bolores e leveduras à medida que se elevou o período de armazenamento. A partir do sexto dia de armazenamento, foi obtido contagem superior a $3,00 \log \mathrm{UFC}^{-1}$.

Tabela 3 - Valores médios referentes ao contagem de bolores e leveduras (log UFC g ${ }^{-1}$ ) em morangos submetidos ozonização e armazenados por 12 dias a $5^{\circ} \mathrm{C}$

\begin{tabular}{lllll}
\hline \multicolumn{4}{l}{ Período de armazenamento (dias) } \\
\hline 0 & 3 & 6 & 9 & 12 \\
\hline $2,20 \mathrm{~b}$ & $2,38 \mathrm{~b}$ & $3,69 \mathrm{a}$ & $3,33 \mathrm{a}$ & $3,53 \mathrm{a}$ \\
\hline
\end{tabular}

Médias seguidas de mesma letra não diferem estatisticamente entre si, pelo Tukey a $5 \%$ de probabilidade.

Destaca-se que apesar de não ter ocorrido variação significativa na contagem de bolores e leveduras nos morangos em função da exposição ao ozônio, encontram-se na literatura diversos trabalhos que comprovam a eficácia do composto, aplicado tanto na forma gasosa quanto dissolvido na água, sobre esse grupo de microrganismos. Palou et al. (2001) aplicaram ozônio gasoso com o intuito de diminuir Penicilium digitatum e Penicilium italicum em citros. Os autores observaram retardamento de uma semana na incidência dos fungos nos frutos. Alexopoulos et al. (2013) avaliaram a eficiência de ozônio dissolvido na água no controle de bolores e leveduras em alface e obtiveram redução de 2,14 ciclos log, quando se adotou a concentração de $0,5 \mathrm{mg} \mathrm{L}^{-1}$, por período de exposição de 30 minutos. Alencar et al. (2014) ozonizaram peras com gás ozônio na concentração de 100 ppm, por 60 minutos, e não observaram aumento significativo na contagem de bolores e leveduras por até 13 dias de armazenamento. Entretanto, os autores obtiveram contagem equivalente a 3,0 log UFC $\mathrm{g}^{-1}$ nos frutos não submetidos a ozonização, depois de 13 dias de armazenamento.

No que tange a contagem de mesófilos aeróbios nos morangos, verificou-se variação significativa em decorrência da interação entre tratamento e período de armazenamento $(\mathrm{p}<0,05)$. Encontram-se, na Tabela 4, os valores médios referentes à contagem de mesófilos aeróbios (log UFC $\mathrm{g}^{-1}$ ) em morangos ozonizados em diferentes combinações de período de exposição (min) e concentração do gás (ppm) e armazenados a $5{ }^{\circ} \mathrm{C}$.

Verificou-se, no início do armazenamento, que a contagem de mesófilos aeróbios nos frutos ozonizados nas concentrações de 1.000 e 2.000 ppm, por 60 minutos, diferiram significativamente $(\mathrm{p}<0,05)$ da contagem obtida no tratamento controle (frutos não 
ozonizados), conforme apresentado na Tabela 4. Obteve-se reduções equivalentes a 0,65 e 1,01 ciclo log nos frutos ozonizados nas concentrações de 1.000 e 2.000 ppm, por 60 minutos, respectivamente.

Outra tendência observada foi a redução significativa $(\mathrm{p}<0,05)$ na contagem de mesófilos aeróbios no terceiro dia de armazenamento nos frutos ozonizados nas concentrações de 1.000 ppm, por 60 minutos, e 2.000 ppm, por 30 e 60 minutos, em comparação aos valores médios obtidos no início do armazenamento. A maior redução foi observada nos frutos ozonizados na concentração de 2.000 ppm, quando se adotou período de exposição ao gás de 30 minutos, sendo equivalente a 1,92 ciclo log. Posteriormente, ocorreu elevação na contagem de mesófilos aeróbios no tratamento citado anteriormente.

Tabela 4 - Valores médios referentes à contagem de mesófilos aeróbios (log UFC $\mathrm{g}^{-1}$ ) em morangos ozonizados em diferentes combinações de período de exposição (min) e concentração do gás (ppm) e armazenados a $5{ }^{\circ} \mathrm{C}$

\begin{tabular}{lccccc}
\hline \multirow{2}{*}{ Tratamento } & \multicolumn{5}{c}{ Período de armazenamento (dias) } \\
& 0 & 3 & 6 & 9 & 12 \\
\hline Controle & $2,91 \mathrm{Aa}$ & $2,98 \mathrm{Aa}$ & $2,64 \mathrm{Aa}$ & $2,64 \mathrm{Aa}$ & $2,84 \mathrm{Aa}$ \\
$1.000 \mathrm{ppm} / 30 \mathrm{~min}$ & $2,76 \mathrm{Aa}$ & $2,10 \mathrm{Aa}$ & $2,51 \mathrm{Aa}$ & $2,56 \mathrm{Aa}$ & $2,48 \mathrm{Aa}$ \\
$1.000 \mathrm{ppm} / 60 \mathrm{~min}$ & $2,26 \mathrm{Ba}$ & $1,00 \mathrm{Ab}$ & $1,91 \mathrm{Aab}$ & $2,65 \mathrm{Aa}$ & $2,72 \mathrm{Aa}$ \\
$2.000 \mathrm{ppm} / 30 \mathrm{~min}$ & $2,65 \mathrm{Aa}$ & $0,73 \mathrm{Bb}$ & $2,45 \mathrm{Aa}$ & $2,03 \mathrm{Aa}$ & $2,48 \mathrm{Aa}$ \\
$2.000 \mathrm{ppm} / 60 \mathrm{~min}$ & $1,90 \mathrm{Cab}$ & $1,36 \mathrm{Ab}$ & $2,58 \mathrm{Aa}$ & $2,42 \mathrm{Aa}$ & $2,96 \mathrm{Aa}$
\end{tabular}

Médias seguidas de mesma letra minúscula na linha e letra maiúscula na coluna não diferem estatisticamente entre si, pelo Tukey a $5 \%$ de probabilidade.

É importante ressaltar que esse comportamento observado na contagem de mesófilos aeróbios nos morangos entre o início e terceiro dia de armazenamento precisa ser elucidado. Uma possível razão para a redução observada na contagem de mesófilos aeróbios no terceiro dia é o efeito do gás na célula e/ou esporos dos microrganismos. O ozônio possui um elevado potencial oxidativo e é capaz de initivar ou inibir o desenvolvimento de microrganismos a partir da oxidação de componentes celulares vitais, tais como constituintes da membrana e da parede celular, como os ácidos graxos insaturados, assim como elementos do conteúdo celular, como enzimas e ácidos nucléicos. Os microrganismos são inativados pelo rompimento da célula, em decorrência da ação do ozônio molecular ou dos radicais livres gerados durante a decomposição do gás (GUZEL-SEYDIM et al., 2004; PASCUAL et al., 
2007; CULLEN et al., 2009). Encontram-se na literatura diversos trabalhos que comprovam que o ozônio é capaz de inativar bactérias Gram-positivas (Listeria monocytogenes, Staphylococcus aureus, Enterococcus faecalis) e bactérias Gram-negativas (Escherichia coli, Salmonella typhimurium, Yersinia enterocolitica e Pseudomonas aeruginosa (GRAHAM, 1997; WU et al., 2006; AGUIRRE; CÁNOVAS, 2013; SUNG et al., 2014; SONG et al., 2015). Dependendo da concentração e período de exposição ao gás, é possível que quantidade significativa de células e/ou esporos de microrganismos não sejam inativadas, mas o processo de multiplicação seja comprometido, inclusive o processo de esporulação. Nesse contexto, Vijayanandraj et al. (2008) expuseram esporos de Aspergillus niger ao ozônio e, apesar do tratamento com gás não evitar o processo de germinação dos mesmos, as colônias formadas se caracterizaram como não esporulantes.

\section{CONCLUSÕES}

Concluiu-se, a partir dos resultados obtidos, que: a ozonização, nas condições adotadas, não afeta significativamente a contagem de bolores e leveduras, apesar de ter ocasionado redução de 0,82 ciclo log, quando se adotou a concentração do gás de 2.000 ppm, por 60 minutos. A exposição dos morangos ao gás ozônio possibilita redução na contagem de mesófilos aeróbios. A ozonização se mostrou um método promissor, no que tange o controle de microrganismos em morangos produzidos em sistema orgânico. É importante a realização de outros trabalhos, adotando-se diferentes combinações de concentração e período de exposição ao gás, de tal forma que se consiga aumentar a eficácia do método no controle dos microrganismos, sobretudo de bolores e leveduras. 


\section{REFERENCIAS BIBLIOGRÁFICAS}

AGUAYO, E.; JANSASITHORN, R.; KADER, A.A. Combined effects of 1methylcyclopropene, calcium chloride dip, and/or atmospheric modification on quality changes in fresh-cut strawberries. Postharvet Biology and Technology, v.40, p.269-278, 2006.

AGUIRRE, D.B.; CÁNOVAS, G.V.B. Disinfection of selected vegetables under nonthermal treatments: Chlorine, acid citric, ultraviolet light and ozone. Food Control, v.29, p.82-90, 2013.

AKBAS, M.Y.; OZDEMIR, M. Application of gaseous ozone to control populations of Escherichia coli, Bacillus cereus and Bacillus cereus spores in dried figs. Food Microbiology, New York, v.25, p.386-391, 2008.

ALENCAR, E. R.; FARONI, L.R.D.; PINTO, M.S.; COSTA, A.R. Postharvest quality of ozonized nanicão cv. Bananas. Revista Ciência Agronômica, v.44, p. 107-114, 2013.

ALENCAR, E.R.; FARONI, L.R.D.; PINTO, M.S.; COSTA, A.R.; CARVALHO, A.F. Effectiveness of Ozone on Postharvest Conservation of Pear (Pyrus communis L.). Journal Food Processing \& Technology, v.5, p.317-321, 2014.

ALEXOPOULOS, A.; PLESSAS, S.; CECIU, S.; LAZAR, V.; MANTZOURANI, I.; VOIDAROU, C.; STAVROPOULOU, E.; BEZIRTZOGLOU, E.. Evaluation of ozone efficacy on the reduction of microbial population of fresh cut lettuce (Lactuca sativa) and green bell pepper (Capsicum annuum). Food Control, v.30, p.491-496, 2013.

BEUCHAT, L.R.; NAIL, B.V.; ADLER, B.B.; CLAVERO, M.R. Efficacy of spray application of chlorinated water in killing pathogenic bacteria on raw apples, tomatoes, and lettuce. Journal of Food Protection, v.61, n.10, p.1305-11, 1998.

BRASIL. Ministério da Agricultura, Pecuária e Abastecimento. Instrução Normativa $\mathrm{n}^{\circ}$ 62, de 26 de agosto de 2003. Métodos Analíticos Oficiais para Análises Microbiológicas para Controle de Produtos de Origem Animal e Água. Diário Oficial da União, Brasília, DF, 2003.

BRASIL. AGÊNCIA NACIONAL DE VIGILÂNCIA SANITÁRIA. Resolução RDC $\mathrm{n}^{\circ} 12$, de 02/01/2001. Regulamento Técnico sobre padrões microbiológicos para alimentos. Diário Oficial da República Federativa do Brasil, Brasília, DF, 10 jan. 2001, Seção I, p. 45-53.

CALVETE, E.O.; MARIANI, F.; WESP, C.L.; NIENOW, A.A.; CASTILHOS, T.; CECCHETTI, D.. Revista Brasileira de Fruticultura, v.30, n.2, p.396-401, 2008.

CLESCERI, L.S.; GREENBERG, A.E. EATON, A.D. Standard methods for the examination of water and wastewater. Denver: American Water Works Association, 1220p, 2000. 
CULLEN, P.J.; TIWARI, B.K.; O’DONNELL, C.P.; MUTHUKUMARAPPAN, K. Modelling approaches to ozone processing of liquid foods. Trends in Food Science \& Technology, Amsterdam, v.20, p.125-136, 2009.

FDA. Food and Drug Administration. Secondary direct food additives permitted in food for human consumption. Federal Register, v.66, n.123, p.33829-33830, 2001.

FRANCO, G. Tabelas de composição química dos alimentos. São Paulo: Atheneu, 2002, $303 p$.

GIAMPIERI, F.; TULIPANI, S.; ALVAREZ-SUAREZ, J.M.; QUILES, J.L.; MEZZETTI, B.; BATTINO, M. The strawberry: Composition, nutritional quality, and impact on human health. Nutrition, v.28, p. 9.12, 2012.

GRAHAM, D.M. Use of ozone for food processing. Food Technology, v.51, p.72-75, 1997.

GUZEL-SEYDIM, Z. B.; GREENE, A. K., \& SEYDIM, A. C. Use of ozone in the food industry. LWT - Food Science and Technology, 37, 453-460. 2004.

HENRIQUES, A.T.; BASSANI, V.L.; RASEIRA, M. do C.; ZUANAZZI, J.A. Antocianos e capacidade antioxidante de frutas. In: Simpósio Nacional do Morango, 2., Encontro De Pequenas Frutas E Frutas Nativas, 1., 2004, Pelotas. Anais... Pelotas: Embrapa Clima Temperado, 2004. p.271-282. (Documentos, 124).

HENZ GP; REIS A; SILVA KCC; PEREIRA SF. Incidência de Doenças de Pós-Colheita em Frutos de Morango Produzidos no Distrito Federal. Brasília: Embrapa Hortaliças. 2008. 13p.

KHADRE, M.A.; YOUSEF, A.E.; KIM, J.G. Microbiological Aspects of Ozone Applications in Food: A Review. Journal of Food Science, v.66, n.9, p.1242-1252, 2001.

KIM, J.G; YOUSEF, A.E.; DAVE, S. Application of ozone for enhancing the microbiological safety and quality of foods: a review. Journal Food Protection, v. 62, n. 9, p. 1071-1087, 1999.

LELIEVELD, H.L.M.; MOSTERT, M.A.; HOLAH, J.; WHITE, B. Hygiene in food processing. Boca Raton: CRC Press, 2003. 421p.

MUSTAFA, M.G. Biochemical basis of ozone toxicity. Free Radical Biology and Medicine, v.9, p.245-265, 1990.

NASCIMENTO, M.S.; SILVA, N. Tratamentos químicos na sanitização de morango (Fragaria vesca L). Brazilian Journal of Food Technology. v.13, n.1, p.11-17. 2010.

NOTERMANS, S.; ZNADVOORT-ROELOFSEN, J. S. V.; BARENDSZ, A. W.; BECZNER, J. Risk profile for strawberries. Food Protection Trends. v. 24, n. 10, p.730-739, 2004. 
OSKAN, R.; SMILANICK, J.L.; KARABULUT, O.A. Toxicity of ozone gas to conidia of Penicillium digitatum, Penicillium italicum, and Botrytis cinerea and control of gray mold on table grapes. Postharvest Biology and Technology, v. 60, p. 47-51, 2011.

PALOU, L.; SMILANICK, J. L.; CRISOSTO, C.H.; MANSOUR, M. Effect of gaseous ozone on the development of green and blue molds on cold stored citrus fruit. Plant Disease, v. 85, p. 632-638, 2001.

PASCUAL, A.; LLORCA, L.; CANUT, A. Use of ozone in food industries for reducing the environmental impact of cleaning and disinfection activities. Trends in Food Science \& Technology, v. 18, p. S29-S35, 2007.

PATIL, S.; VALDRAMISIS, V.; FRIAS, J.M.; CULLEN, P.; BOURKE, P. Ozone inactivation of acid stressed Listeria monocytogenes and Listeria innocua in orange juice using a bubble column. Food Control, v. 21, n. 13, p. 1723-1730, 2010.

PROTEGGENTE, A.R.; PANNALA, A.S.; PAGANGA, G.; VAN BUREN, L.; WAGNER, E.; WISEMAN, S.; VAN DE PUT, F.; DACOMBE, C.; RICE-EVANS, C.A. The antioxidant activity of regularly consumed fruits and vegetables reflects their phenolic and vitamin $\mathrm{C}$ composition. Free Radical Research, v.36, p.217-233, 2002.

RAILA, A.; LUGAUSKAS, A.; STEPONAVIČIUS, D.; RAILIENÉ, M.; STEPONAVIČIENE, A.; ZVICEVIČIUS, E. Application of ozone for reduction of mycological infection in wheat grain. Annals of Agricultural and Environmental Medicine, v.13, n.2, p.287-294, 2006.

ROCHA, D.A.; ABREU, C.M.P.; CORRÊA, A.D.; SANTOS, C.D.; FONSECA, E.W.N. Análise comparativa de nutrientes funcionais em morangos de diferentes cultivares da região de Lavras-MG. Revista Brasileira de Fruticultura, v.30, n.4, p.1124-1128, 2008.

SEERAM, NP.; ADAMS, LS.; ZHANG, Y.Blackberry, black raspberry, blueberry, cranberry red raspberry, and strawberry extracts inhibit growth and stimulate apoptosis of human cancer cells in vitro. Journal of Agricultural and Food Chemistry, v. 54, p. 9329-9339, 2006.

SILVA, JR., E. A. Manual de controle higiênico sanitário em alimentos. São Paulo: Livraria Varela, 2001.

SIVAPALASINGAM, S.; FRIEDMAN, C.R.; COHEN, L.; TAUXE, R.V. Fresh produce: a growing cause of outbreaks of foodborne illness in the United States, 1973 through 1997. Journal of Food Protection, v.67, n.10, p.2342-2353, 2004.

SONG, W.J.; SUNG, H.J.; KANG, D.H. Inactivation of Escherichia coli O157:H7 and Salmonella typhimurium in apple juices with different soluble solids content by combining ozone treatment with mild heat. Journal of Applied Microbiology, v. 118, p.112-122, 2015. 
STEENSTRUP, L.D.; FLOROS, J. Inactivation of E. coli O157:H7 in apple cider by ozone at various temperatures and concentrations. Journal of Food Processing and Preservation, v. 28, n. 2, p. 103-116, 2004.

SUNG, H.J.; SONG, W.J.; KIM, K.P.; RYU, S.; KANG, D.H. Combination effect of ozone and heat treatments for the inactivation of Escherichia coli O157:H7, Salmonella typhimurium, and Listeria monocytogenes in apple juice. International Journal of Food Microbiology, v.171, p.147-153, 2014.

TORLAK, E.; SERT, D.; ULCA, P. Efficacy of gaseous ozone against Salmonella and microbial population on dried oregano. International Journal of Food Microbiology, v. 165, n. 3, p. 276-280, 2013.

VIJAYANANDRAJ, V.R.; PRASAD, D.N.; MOHAN, N.; GUNASEKARAN, M. Effect of ozone on Aspergillus niger causing black rot disease in onion. Ozone: Science and Engineering, 28: 347-350, 2006.

WU, J.; DOAN, H.; CUENCA, M.A. Investigation of gaseous ozone as an anti-fungal fumigant for stored wheat. Journal of Chemical Technology \& Biotechnology, v. 81, n. 7, p. 1288-1293, 2006.

ZAMBOLIM, L.; COSTA. H. Manejo integrado de doenças do morangueiro. In: CARVALHO, S. P. (Coord.).Boletim do morango: cultivo convencional, segurança alimentar, cultivo orgânico. Belo Horizonte: CEASA Minas, 2005. p. 55-96.

ZOTTI, M.; PORRO, R.; VIZZINI, A.; MARIOTTI, M.G. Inactivation of Aspergillus spp. by ozone treatment. Ozone-Science \& Engineering, v. 30, n. 6; p. 423-430, 2008. 
CAPITULO II

EFEITO DO OZÔNIO NA QUALIDADE PÓS-COLHEITA DE MORANGOS PRODUZIDOS EM SISTEMA ORGÂNICO 


\section{EFEITO DO OZÔNIO NA QUALIDADE PÓS-COLHEITA DE MORANGOS PRODUZIDOS EM SISTEMA ORGÂNICO}

\section{RESUMO}

Apesar da ozonização ainda não é permitida no Brasil para alimentos orgânicos, é importante a obtenção de dados com comprovem a capacidade do ozonização na manutenção da qualidade pós-colheita de alimentos produzidos em sistema orgânico de tal forma a subsidiar a inclusão dessa técnica dentre as permitidas. Em vista disso, objetivou-se com este trabalho avaliar o efeito do ozônio aplicado em diferentes condições na qualidade pós-colheita de morango produzido em sistema orgânico. Foram utilizados morangos orgânicos da variedade "Festival". Os morangos foram divididos em cinco lotes correspondendo aos tratamentos: morangos não ozonizados - controle; morangos ozonizados na concentração de 1000 ppm durante 30 min; morangos ozonizados na concentração de 1000 ppm durante 60 min; morangos ozonizados na concentração de 2000 ppm durante 30 min; morangos ozonizados na concentração de 2000 ppm durante 60 min. Após a ozonização, os frutos foram armazenados em câmara fria a $5{ }^{\circ} \mathrm{C}$ por 12 dias. As avaliações qualitativas dos frutos foram realizadas no dia da ozonização (tempo zero) e a cada três dias de armazenamento. As variáveis avaliadas foram percentual de perda de massa fresca, $\mathrm{pH}$, teor de Vitamina $\mathrm{C}$, sólidos solúveis totais, acidez titulável, acidez titulável, relação entre sólidos solúveis totais, saturação, tonalidade e diferença de cor. Adotou-se Delineamento Inteiramente Casualizado em esquema fatorial 5X5, sendo cinco tratamentos e cinco períodos de armazenamento (0, 3, 6, 9 e 12 dias), com quatro repetições. Inicialmente realizou-se análise de variância e posteriormente análise de regressão. O percentual de perda de massa fresca foi menos intenso nos frutos ozonizados. Em geral, as variáveis pH e sólidos solúveis totais apresentaram mesma tendência em frutos ozonizados ou não. Não houve variação significativa em função da exposição ao ozônio nas variáveis acidez titulável, relação entre sólidos solúveis totais, saturação, tonalidade de cor. Com relação a diferença de cor, ocorreu aumento menos intenso nos frutos ozonizados. É possível concluir, a partir dos resultados obtidos, que a ozonização pode ser considerada é uma importante alternativa para a manutenção da qualidade pós-colheita de morangos produzidos em sistema orgânico.

Palavras-chave: ozônio, qualidade, armazenamento, morango orgânico. 


\section{OZONE'S EFFECT ON THE QUALITY OF STRAWBERRY POSTHARVEST PRODUCED IN ORGANIC SYSTEM}

\section{ABSTRACT}

Despite the ozonation still not be allowed in Brazil to organic foods, it is important to obtain data to prove the ozonation of capacity in maintaining food postharvest quality produced in organic system in such a way to support the inclusion of this technique that is permitted. Considering this, the aim of this work was to evaluate the effect of ozone applied in different conditions in the strawberry postharvest quality produced in an organic system. Organic strawberries variety used in this research were Festival type. The strawberries were divided into five lots corresponding to the treatments: not ozonated strawberries - control; strawberries ozonized at 1000 ppm for $30 \mathrm{~min}$; strawberries ozonized at $1000 \mathrm{ppm}$ for $60 \mathrm{~min}$; strawberries ozonized at a concentration of 2,000 ppm for $30 \mathrm{~min}$; strawberries ozonized at a concentration of 2,000 ppm for $60 \mathrm{~min}$. After ozonation, the fruits were stored in cold storage at $5^{\circ} \mathrm{C}$ for 12 days. The qualitative assessments of fruits were held on the ozonation (time zero) and every three days of storage. The variables: percentage of weight loss, $\mathrm{pH}$, vitamin $\mathrm{C}$ content, total soluble solids, titratable acidity, titratable acidity, soluble solids ratio, saturation, hue and color difference. completely randomized design in factorial 5x5 was adopted, with five treatments and five storage periods $(0,3,6,9$ and 12 days), with four replications. Initially analysis was performed by ANOVA and subsequent regression analysis. The mass loss rate was less intense in ozonated fruit. In general, $\mathrm{pH}$ and soluble solids showed the same trend ozonized fruits or not. There was no significant variation due to exposure to ozone in the variables titratable acidity, ratio of total soluble solids, saturation or color tone. Regarding the color difference, it has been less intense increase in ozonated fruit. Considering the results, the ozonation is an important alternative to maintaining strawberries post-harvest quality produced in the organic system.

Keywords: ozone, quality, storage, organic strawberry 


\section{INTRODUÇÃO}

Atualmente a produção mundial do morango (Fragaria Ananassa Duch.) é de aproximadamente 4,52 milhões de toneladas (FAO, 2014). A produção brasileira estimada em 2007 foi de cerca de 100 mil toneladas, com expansão significativa a cada ano (PONCE et al., 2010; RANDIN et al., 2011).A produção do Distrito Federal é de cerca de 6.500 toneladas (EMATER-DF, 2014). Devido aos vantajosos atributos próprios do fruto que são uma conjugação de componentes como: a cor vermelha, o brilho, sabor, textura e odor são muito apreciados pelos consumidores; além de possuir 2,3\% de fibras, 92,8\% de água, 39 calorias e 72,80 mg de vitamina C em 100 g de frutos, vitaminas B1, B2, e B5 e compostos fenólicos que atuam como antioxidantes e estão ligados à redução da maioria das doenças crônicas de risco, principalmente as degenerativas (FRANCO, 2002; HENRIQUES et al., 2004).

O consumidor apresenta uma preferência de consumo in natura da fruta, sendo um dos fatores mais importantes frutos isentos de resíduos de pesticidas que garantam a segurança do alimento onde a demanda por o consumo de produtos orgânicos cada vez é maior (KADER; BARRET, 2005). Considera-se também um grande problema do morango é a alta susceptibilidade à deterioração ou contaminação dos frutos nas diferentes etapas de cultivo o que provoca uma curta vida pós-colheita, e sem a devida segurança sanitária. É importante garantir um adequado manejo de cultivo. As medidas de controle das podridões dos frutos devem iniciar nos campos de plantio, passando pela colheita e embalagem cuidadosa (ZAMBOLIM; COSTA, 2005). Aproximadamente um 40\% do total da produção do morango acontece nas fases de pós-colheita e armazenamento (CANER; ADAY; DEMIR, 2008).

Os métodos de sanitização são utilizados como parte da cadeia produtiva na conservação e sanidade do produto até chegar ao consumidor. Atualmente o cloro e seus produtos derivados são os mais utilizados na higienização das verduras e frutas. A legislação brasileira tem aceitado o uso do cloro na sanitização dos alimentos, na etapa pós-colheita. No entanto, Lazarova (1999) menciona que as principais desvantagens do processo de sanitização com cloro é a formação de subprodutos químicos mutagênicos, em água e alimentos.

Uma das técnicas que tem sido proposta como alternativa na manutenção da qualidade pós-colheita de produtos de origem vegetal é a ozonização. O ozônio se destaca por seu elevado potencial oxidativo, o que o torna eficiente na inativação de microrganismos, tais como bactérias, fungos e vírus (DOSTI et al., 2005). Diversos trabalhos indicam que o ozônio 
é capaz de inativar bactérias Gram-positivas (Listeria monocytogenes, Staphylococcus aureus, Enterococcus faecalis), bactérias Gram-negativas (Escherichia coli, Salmonella typhimurium, Yersinia enterocolitica, Pseudomonas aeruginosa), vírus, fungos (Cândida parapsilosis, Candida tropicalis e dos generos dos gêneros Fusarium, Geotrichum, Myrothecium e Mucor, dentre outros (GRAHAM, 1997; RAILA et al., 2006; WU et al., 2006).

No que se refere a alimentos produzidos em sistema orgânicos, salienta-se que o ozônio gasoso ainda não é permitido pela legislação brasileira. Entretanto, é permitido o uso de atmosfera modificada com gás nitrogênio ou dióxido de carbono (BRASIL, 2014). Nesse sentido, a obtenção de dados com comprovem a capacidade do ozonização na manutenção da qualidade pós-colheita de alimentos produzidos em sistema orgânico poderá subsidiar a inclusão dessa técnica dentre as permitidas. Outro aspecto que deve ser mencionado, é que o ozônio é gerado a partir do oxigênio e o produto de sua degradação é esse mesmo elemento (NOVAK; YUAN, 2007).

Diante do exposto, objetivou-se com este trabalho avaliar o efeito do ozônio aplicado em diferentes condições na qualidade pós-colheita de morango produzido em sistema orgânico. 


\section{MATERIAL E MÉTODOS}

O experimento foi conduzido no Laboratório de Pré-Processamento e Armazenamento de Produtos de Vegetais, no Laboratório de Análise de Alimentos e no Laboratório de Microbiologia de Alimentos (LAMAL), todos localizados na Faculdade de Agronomia e Medicina Veterinária, na Universidade de Brasília, UnB, localizada no Distrito Federal.

\subsection{Obtenção dos morangos}

Os morangos (Fragaria ananassa Duch) da variedade "Festival" foram adquiridos diretamente de um produtor orgânico da região administrativa de Brazlândia no Distrito Federal, no dia 27/05/2014. Os frutos foram coletados pela tarde no estado de maturação comercial (3/4 maturação), depois foram transportados para o Laboratório de PréProcessamento e Armazenamento de Produtos Vegetais, colocados sobre refrigeração, a $5^{\circ} \mathrm{C}$ por um período de aproximadamente 12 horas. No dia seguinte, os morangos foram devidamente selecionados, aqueles que apresentaram ferimentos ou lesões foram descartados e somente os frutos uniformes, sadios e sem defeitos foram submetidos ao processo de ozonização.

\subsection{Geração do ozônio e determinação da concentração do gás}

Na geração do ozônio foi utilizado o gerador de ozônio, Modelo O\&L 3.0-O2 RM). O equipamento funciona entre dois eletrodos paralelos, entre eles existe um dielétrico, e um espaço livre por onde percorre o ar seco. Neste espaço é produzida uma descarga em forma de filamentos, constituída por elétrons com energia suficiente para ocasionar a quebra das moléculas de oxigênio, formando o ozônio $\left(\mathrm{O}_{3}\right)$. Neste processo de geração do ozônio, a matéria prima é o oxigênio $\left(\mathrm{O}_{2}\right)$, obtido do concentrador de oxigênio que se acopla ao gerador. A vazão adotada para a geração do ozônio foi de $2,0 \mathrm{~L} \mathrm{~min}^{-1}$, na temperatura de 25 ${ }^{\circ} \mathrm{C}$.

A quantificação da concentração inicial de ozônio foi determinada pelo método iodométrico, através da titulação indireta (APHA, 1985). Esse método consiste no borbulhamento do ozônio residual durante 1 minuto, em $50 \mathrm{~mL}$ de solução de iodeto de potássio $(\mathrm{KI}) 1 \mathrm{~N}$, liberando iodo $\left(\mathrm{I}_{2}\right)$; adicionando $2,5 \mathrm{~mL}$ de ácido sulfúrico $1 \mathrm{~N}\left(\mathrm{H}_{2} \mathrm{SO}_{4}\right)$ 
0,01 N, reduzindo assim, o pH. Em seguida, é necessária a realização da titulação com tiossulfato de sódio $\left(\mathrm{Na}_{2} \mathrm{~S}_{2} \mathrm{O}_{3}\right) \quad 0,1 \mathrm{M}$, até que a coloração amarela do iodo se torne clara de forma imediata, por fim, foi adicionando amido $1 \%$,até o desaparecimento da coloração azul.

\subsection{Ozonização dos morangos}

Os morangos, devidamente selecionados, foram divididos em cinco lotes correspondendo aos tratamentos:

- Morangos não ozonizados - tratamento controle;

- Morangos ozonizados na concentração de 1000 ppm durante 30 minutos;

- Morangos ozonizados na concentração de 1000 ppm durante 60 minutos;

- Morangos ozonizados na concentração de 2000 ppm durante 30 minutos;

- Morangos ozonizados na concentração de 2000 ppm durante 60 minutos.

Os frutos foram colocados em recipientes de vidro com capacidade de $3,0 \mathrm{~L}$ de volume e submetidos ao processo de ozonização, com quatro repetições cada tratamento. Após a ozonização, os frutos foram colocados em embalagens de polietileno retangulares (12 cm x $18 \mathrm{~cm}$ ), transparentes e com a devida identificação, sendo colocados 10 frutos por embalagem, correspondendo a aproximadamente (100 g). Posteriormente, as embalagens contendo os frutos foram armazenadas aleatoriamente em uma câmara fria a $5{ }^{\circ} \mathrm{C}$. As avaliações qualitativas dos frutos foram realizadas no dia da ozonização (tempo zero) e a cada três dias até 12 dias de armazenamento.

\subsection{Avaliação da qualidade pós-colheita dos morangos submetidos à ozonização em diferentes condições}

\subsubsection{Perda de massa fresca (PMF)}

A perda de massa fresca foi estimada, em porcentagem (\%), pela diferença da massa registrada no momento no início do experimento (dia zero) e os diferentes dias de armazenamento (3, 6, 9 e 12 dias). A perda de massa foi calculada utilizando-se a Equação 1:

$$
\begin{array}{ll}
\text { Perda de massa }(\%)=\frac{M_{1}-M_{f}}{M_{1}} 100 \quad \text { Equação } 1
\end{array}
$$




\subsubsection{Potencial Hidrogeniônico $(\mathrm{pH})$}

$\mathrm{O}$ pH foi determinado com o potenciômetro Digimed Mod. DM21. Utilizou-se aproximadamente 10 gramas de amostra triturada e homogeneizada em $100 \mathrm{~mL}$ de água destilada.

\subsubsection{Teor de Vitamina $\mathrm{C}$}

Para a determinação do teor de vitamina $\mathrm{C}$, os morangos foram triturados e homogeneizados com $50 \mathrm{ml}$ de água destilada, sendo adicionados $20 \mathrm{ml}$ de solução de ácido sulfúrico $0,002 \mathrm{M}, 1 \mathrm{ml}$ de amido (usado como indicador) e para a titulação foi utilizado Iodeto de Potássio 0,02 M, até que a solução passou da cor vermelha para azul escuro.

\subsubsection{Sólidos Solúveis Totais (SST)}

Os sólidos solúveis totais foram determinados no refratômetro digital Atago (Modelo 1T). Os resultados foram expressos em ${ }^{\circ}$ Brix, segundo a técnica AOAC (2002).

\subsubsection{Acidez titulável (AT)}

A análise de acidez titulável foi determinada conforme a normas descritas pelo Instituto Adolfo Lutz (BRASIL, 2005). Utilizou-se aproximadamente 10 gramas de amostra triturada e homogeneizada em $100 \mathrm{~mL}$ de água destilada, usando como indicador $1 \mathrm{~mL}$ de amido e como titulador a solução de hidróxido de sódio $(\mathrm{NaOH})$ 0,1 N. Os resultados foram expressos em porcentagem de ácido cítrico.

\subsubsection{Relação entre Sólidos Solúveis Totais e Acidez Titulável (SST/AT)}

A partir dos valores obtidos referentes a Sólidos Solúveis Totais e Acidez Titulável foi possível a obtenção da relação SST/AT. 


\subsubsection{Avaliação da coloração dos morangos}

A cor externa do morango foi avaliada usando um colorímetro (Minolta CR 400, Minolta Corporation, Osaka, Japão). O equipamento foi devidamente calibrado e os valores foram tomados em três pontos diferentes de cada fruto, realizando-se três leituras de três morangos selecionados ao acaso de cada amostra obtendo-se os valores de L, a e b.

Com os valores das coordenadas $\mathrm{L}$, a e b foi possível obter parâmetros relacionados à saturação da cor ou croma (C), Equação 2, à tonalidade (h), Equação 3, e diferença de cor (AE), Equação 4 (LITTLE, 1975, FRANCIS, 1975, MCLELLAN et al., 1995, MASKAN, 2001).

$$
\begin{aligned}
& \mathrm{C}=\sqrt{\left(\mathrm{a}^{2}+\mathrm{b}^{2}\right)} \\
& \mathrm{h}=\operatorname{arctang}(\mathrm{b} / \mathrm{a}) \\
& D E=\sqrt{\left[\left(L-L_{0}\right)^{2}+\left[\left(a-a_{0}\right)^{2}+\left[\left(b-b_{0}\right)^{2}\right]\right.\right.}
\end{aligned}
$$

em que:

$\mathrm{h}=$ tonalidade da cor;

$\mathrm{C}=$ saturação da cor ou croma;

$\mathrm{a}=$ mensurável em termos de intensidade de vermelho e verde; e

$\mathrm{b}=$ mensurável em termos de intensidade de amarelo e azul.

$L_{0}, a_{0}$ e $b_{0}$ são os valores obtidos no tempo zero.

\subsection{Delineamento experimental}

Adotou-se Delineamento Inteiramente Casualizado em Esquema Fatorial 5X5, sendo cinco tratamentos e cinco períodos de armazenamento $(0,3,6,9$ e 12 dias), com quatro repetições. Inicialmente realizou-se análise de variância e posteriormente análise de regressão.

Utilizou-se o software Statystics Analysis Systems (SAS) na análise de variância e o software Sigma Plot para a obtenção das equações e plotagem dos gráficos. 


\section{RESULTADOS E DISCUSSÃO}

Obteve-se diferença significativa $(p<0,05)$ em decorrência da interação tratamento e período de armazenamento para a variável percentual de perda de massa fresca. Verificou-se incremento do percentual da perda de massa fresca dos frutos ao longo do armazenamento, sendo essa tendência mais acentuada no tratamento controle (frutos não ozonizados). Incremento menos acentuado ao longo do armazenamento foi observado na Figura 1 frutos ozonizados nas concentrações de 1.000 e 2.000 ppm por 30 minutos.

$\mathrm{Na}$ Tabela 1. são apresentadas as equações das regressões ajustadas e os respectivos coeficientes de determinação referentes ao porcentual de perda de massa fresca nos diferentes tratamentos em função do período de armazenamento.

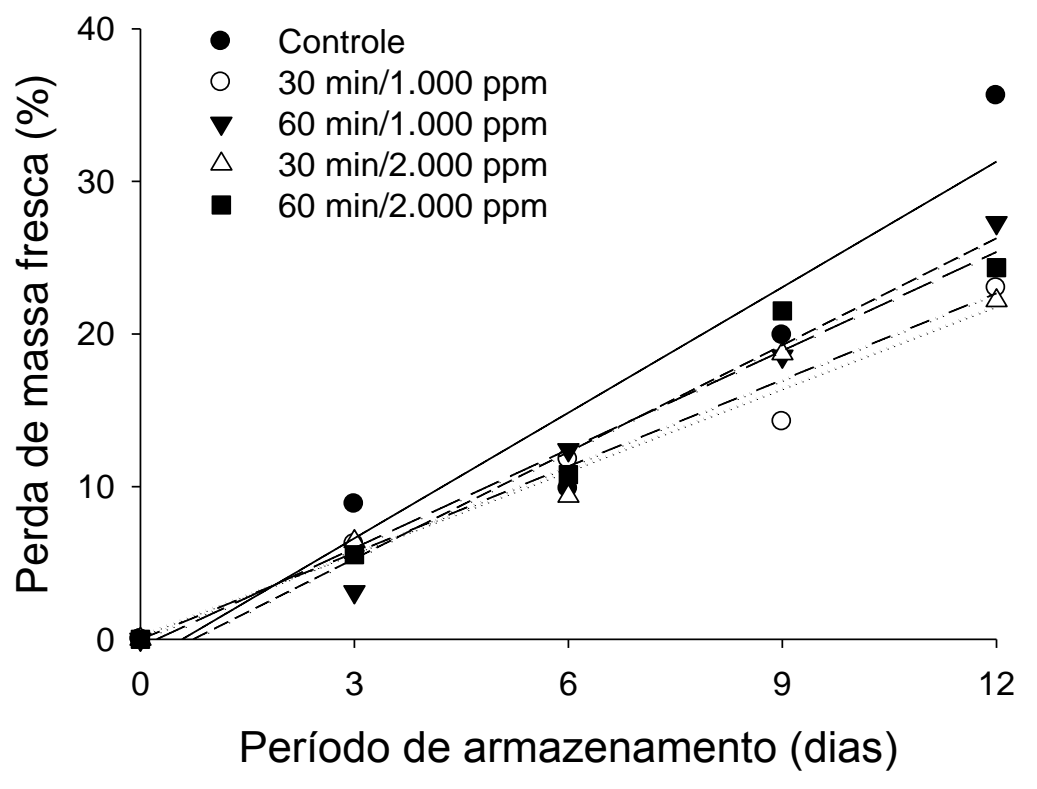

Figura 1 - Perda de massa fresca (\%) em morangos ozonizados em diferentes combinações de concentração do gás (ppm) e período de exposição (min) e armazenados a $5{ }^{\circ} \mathrm{C}$. 
Tabela 1 - Equações de regressão ajustadas e respectivos coeficientes de determinação referentes à perda de massa fresca $(\%)$ em morangos ozonizados em diferentes combinações de concentração do gás (ppm) e período de exposição (min) e armazenados a $5{ }^{\circ} \mathrm{C}$

\begin{tabular}{lcc}
\hline Tratamento & $\begin{array}{c}\text { Equação de regressão } \\
\text { ajustada }\end{array}$ & $\mathrm{R}^{2}$ \\
\hline Controle & $\hat{y}=-1,611+2,742^{*} X$ & 0,92 \\
$1.000 \mathrm{ppm} / 30 \mathrm{~min}$ & $\hat{y}=0,247+1,800^{*} X$ & 0,97 \\
$1.000 \mathrm{ppm} / 60 \mathrm{~min}$ & $\hat{y}=-1,723+1,729^{*} X$ & 0,98 \\
$2.000 \mathrm{ppm} / 30 \mathrm{~min}$ & $\hat{y}=-0,006+1,889^{*} X$ & 0,98 \\
$2.000 \mathrm{ppm} / 60 \mathrm{~min}$ & $\hat{y}=-0,495+2,156^{*} X$ & 0,97
\end{tabular}

**Significativo a $1 \%$ de probabilidade pelo teste $\mathrm{F}$. ${ }^{*}$ Significativo a $5 \%$ de probabilidade pelo teste F.

Resultados semelhantes aos encontrados neste trabalho foram obtidos por outros autores. Holtz (2006) observou perda de massa fresca inferior durante o armazenamento em morangos ozonizados em comparação com frutos submetidos a sanitização com cloro orgânico. Nadas et al. (2003) observaram menor percentual de perda de massa fresca em morangos tratados com $\mathrm{O}_{3}$ e armazenados a $2{ }^{\circ} \mathrm{C}$ por três dias que aqueles não ozonizados. Estes últimos autores consideraram que é provável que o $\mathrm{O}_{3}$ reduziu a perda de massa fresca devido decréscimo na taxa de respiração dos morangos associado a refrigeração.

Por outro lado, Spencer (2003) aplicou ozônio em duas cultivares de batata (Norland e Russet Burbank), e evidenciou perda de massa fresca mínima no controle. Já nas batatas ozonizadas em três diferentes concentrações, o autor verificou que, quanto maior a concentração maior a perda de massa durante o armazenamento. Efeitos análogos foram relatados por Palou et al (2002) no armazenamento de pêssegos que foi exposto a 0,3 ppm de ozônio, a $5{ }^{\circ} \mathrm{C}$ com uma umidade relativa de $90 \%$ durante 6 semanas, observou-se maior perda de massa fresca do que os pêssegos armazenados num ambiente não ozonizado a partir da segunda semana de armazenamento. Esses resultados auxiliam a elucidar o motivo pelo qual houve incremento na perda de massa quando se elevou o período de ozonização (Figura 3). O ozônio possui um alto potencial oxidativo (NOVAK e YUAN, 2007) e elevando-se a concentração do gás ou período de exposição, provavelmente provocou-se danos nos frutos e consequentemente maior perda de massa fresca ao longo do armazenamento.

Outro aspecto que deve ser mencionado é o elevado percentual de perda de massa ao longo do armazenamento em todos os tratamentos. Tal comportamento pode ser explicado 
pelo valor médio de umidade relativa no interior da câmara climática na qual os frutos foram armazenados, que foi equivalente a aproximadamente 70\%. Rahman (2014) avaliou cinco genótipos de morango na fase de pós-colheita. Este estudo incluiu a cultivar Festival que apresentou perdas de massa fresca no primeiro dia de 4,30\% e no quarto dia incrementou a $14,20 \%$, destacando que a taxa da perda de água é largamente controlada pela temperatura e umidade do armazenamento. Umidade relativa baixa produz uma maior gradiente de pressão de vapor de água entre seus tecidos e o ambiente externo. Esses efeitos foram observados em trabalhos desenvolvidos por Finger; Viera (1997); Farinha (2008).

Com relação a variável pH (Figura 2), obteve-se diferença significativa em decorrência da interação entre tratamento e período de exposição $(\mathrm{p}<0,05)$. Entretanto, de acordo com a análise de regressão, Tabela 2, somente para os frutos ozonizados na concentração de 1.000 ppm, por 60 minutos, um dos coeficientes foi significativo a $5 \%$ de probabilidade.

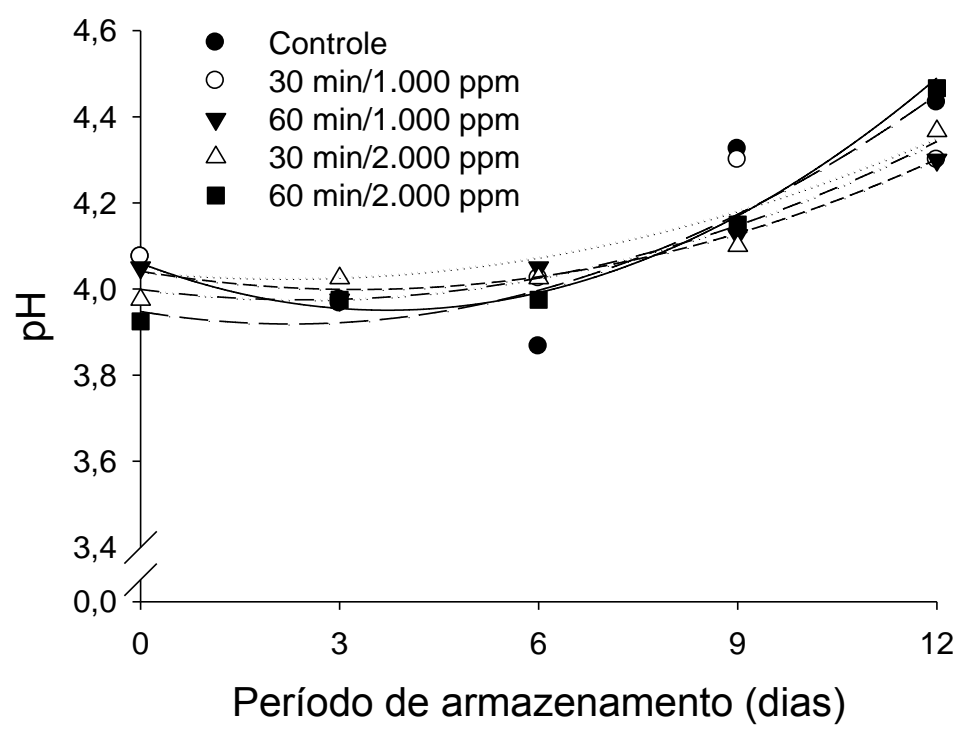

Figura 2 - Curvas referentes ao pH em morangos ozonizados em diferentes combinações de concentração do gás (ppm) e período de exposição (min) e armazenados a $5{ }^{\circ} \mathrm{C}$. 
Tabela 2 - Equações de regressão ajustadas e respectivos coeficientes de determinação referentes ao $\mathrm{pH}$ em morangos ozonizados em diferentes combinações de concentração do gás (ppm) e período de exposição (min) e armazenados a $5{ }^{\circ} \mathrm{C}$

\begin{tabular}{lcc}
\hline Tratamento & \multicolumn{1}{c}{ Equação de regressão ajustada } & $\mathrm{R}^{2}$ \\
\hline Controle & $\hat{y}=4,060-0,059^{n s} X+0,008^{n s} X^{2}$ & 0,81 \\
$1.000 \mathrm{ppm} / 30 \mathrm{~min}$ & $\hat{y}=4,040-0,015^{n s} X+0,003^{n s} X^{2}$ & 0,76 \\
$1.000 \mathrm{ppm} / 60 \mathrm{~min}$ & $\hat{y}=4,041-0,026^{n s} X+0,004^{*} X^{2}$ & 0,98 \\
$2.000 \mathrm{ppm} / 30 \mathrm{~min}$ & $\hat{y}=3,999-0,020^{n s} X+0,004^{n s} X^{2}$ & 0,94 \\
$2.000 \mathrm{ppm} / 60 \mathrm{~min}$ & $\hat{y}=3,948-0,026^{n s} X+0,006^{n s} X^{2}$ & 0,98
\end{tabular}

${ }^{n s}$ Não Significativo a $5 \%$ de probabilidade pelo teste F. *Significativo a $5 \%$ de probabilidade pelo teste F.

Destaca-se que os valores de $\mathrm{pH}$ registrados durante os 12 dias de armazenamento dos morangos nos diferentes tratamentos variaram de 3,46 até 4,46. Esta tendência de aumento do pH durante o armazenamento foi verificado também por Aday; Caner (2014) que usaram 3 técnicas de sanitização (ultrassom, ozônio e dióxido de cloro) na pós-colheita do morango, onde houve um incremento do $\mathrm{pH}$ de 3,32 até 3,81 durante quatro semanas de armazenamento. Resultados semelhantes foram encontrados por Heleno (2013) que usou a ozonização em três concentrações e observou que as amostras de morango controle e ozonizadas apresentaram $\mathrm{pH}$ inicial em torno de 3,3 chegando a um valor médio de 3,6 durante 10 dias de armazenamento.

A vitamina C consiste parte importante dos ácidos orgânicos e é conhecida por suas funções antioxidantes. No que tange ao teor de vitamina $\mathrm{C}$, obteve-se diferença significativa em função da interação tratamento e período de armazenamento. As curvas que descrevem o comportamento do teor der vitamina $\mathrm{C}$ nos frutos submetidos ou não a ozonização encontramse na Figura 3. Nos frutos não ozonizados (tratamento controle) e naqueles ozonizados na concentração de 2.000 ppm por 60 minutos, observou-se tendência de elevação do teor de vitamina $\mathrm{C}$ até o sexto dia de armazenamento, com posterior decréscimo. Por outro lado, nos frutos ozonizados na concentração de 1.000 ppm, por 60 minutos, e na concentração de 2.000 ppm, por 30 minutos, houve tendência de elevação do teor de vitamina $\mathrm{C}$ durante todo período de armazenamento. 
Encontram-se na Tabela 3, as equações de regressão ajustadas e os respectivos coeficientes de determinação referentes ao teor de vitamina $\mathrm{C}$ em morangos ozonizados em diferentes combinações de período de exposição (min) e concentração do gás (ppm) e armazenados a $5{ }^{\circ} \mathrm{C}$.

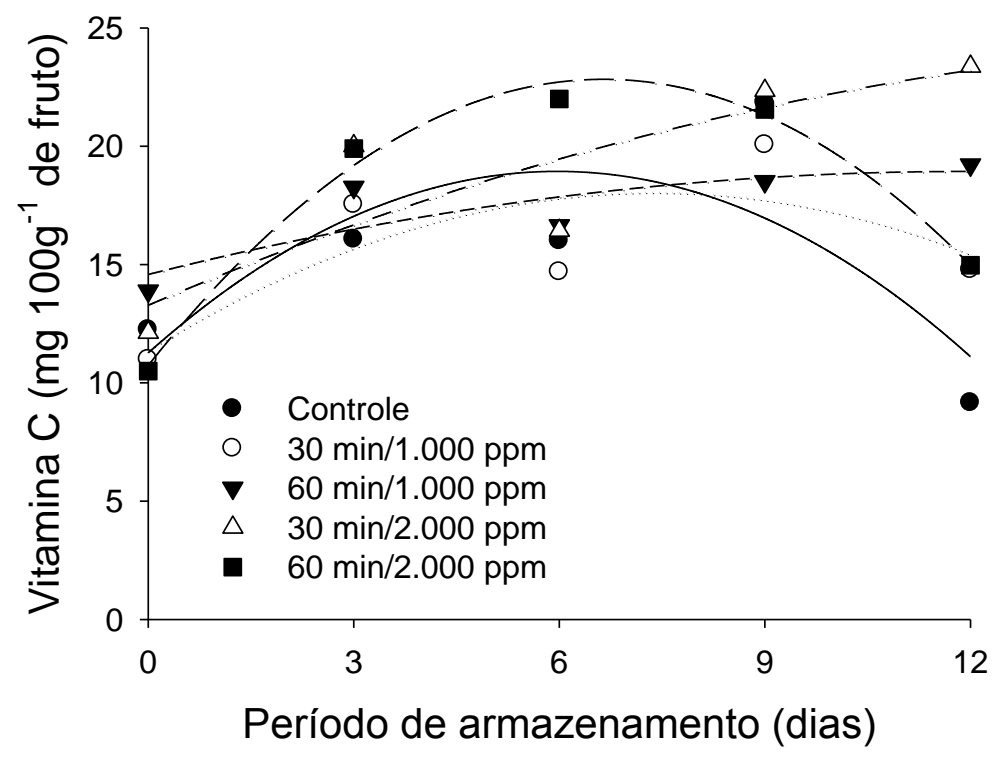

Figura 3 - Teor de Vitamina C (mg $100 \mathrm{~g}^{-1}$ de fruto) em morangos ozonizados em diferentes combinações de concentração do gás (ppm) e período de exposição (min) e armazenados a 5 ${ }^{\circ} \mathrm{C}$.

Tabela 3 - Equações de regressão ajustadas e respectivos coeficientes de determinação referentes à concentração de Vitamina $\mathrm{C}\left(\mathrm{mg} 100 \mathrm{~g}^{-1}\right.$ de fruto) em morangos ozonizados em diferentes combinações de concentração do gás ( $\mathrm{ppm}$ ) e período de exposição (min) e armazenados a $5{ }^{\circ} \mathrm{C}$

\begin{tabular}{lcl}
\hline Tratamento & Equação de regressão ajustada & $\mathrm{R}^{2}$ \\
\hline Controle & $\hat{y}=7,914-0,317^{n s} X+0,026^{n s} X^{2}$ & 0,58 \\
$1.000 \mathrm{ppm} / 30 \mathrm{~min}$ & $\hat{y}=7,430+0,139^{n s} X+0,016^{*} X^{2}$ & 0,59 \\
$1.000 \mathrm{ppm} / 60 \mathrm{~min}$ & $\hat{y}=7,661-0,214^{n s} X+0,018^{\mathrm{ns}} X^{2}$ & 0,71 \\
$2.000 \mathrm{ppm} / 30 \mathrm{~min}$ & $\hat{y}=7,479-0,222^{n s} X+0,019^{n s} X^{2}$ & 0,74 \\
$2.000 \mathrm{ppm} / 60 \mathrm{~min}$ & $\hat{y}=7,438-0,087^{n s} X+0,008^{n s} X^{2}$ & 0,99 \\
\hline
\end{tabular}

${ }^{n s}$ Não Significativo a $5 \%$ de probabilidade pelo teste F. * Significativo a $5 \%$ de probabilidade pelo teste F. 
O decréscimo do teor de vitamina $\mathrm{C}$ durante o armazenamento, semelhante ao observado nos frutos não ozonizados e naqueles ozonizados na concentração de 2.000 ppm por 60 minutos, é um comportamento esperado e está associado ao processo de deterioração, tendo sido observado por outros autores (ALEXANDRE et al., 2012; CARDOSO et al., 2012). De acordo com Cardoso et al. (2012), o decréscimo do teor de vitamina C pode ser explicado pela alta atividade da enzima ácido ascórbico oxidase ou à menor capacidade dos vegetais de sintetizar esse ácido durante o período pós-colheita. Nesse sentido, a ozonização retardou o decréscimo do teor de vitamina $\mathrm{C}$ quando se adotaram as concentrações de $1.000 \mathrm{e}$ $2.000 \mathrm{ppm}$, por 60 e 30 minutos, respectivamente.

Os teores de sólidos solúveis totais estão expressos na Figura 4. Apesar da análise de variância indicar variação significativa pela interação tratamento e período de armazenamento $(p<0,05)$, em geral os coeficientes das equações de regressão não foram significativos $(\mathrm{p}>0,05)$.

Observa-se na Tabela 4 as equações de regressão ajustadas referentes aos teores de sólidos solúveis totais em morangos ozonizados em diferentes combinações de período de exposição (min) e concentração do gás (ppm) e armazenados a $5^{\circ} \mathrm{C}$.

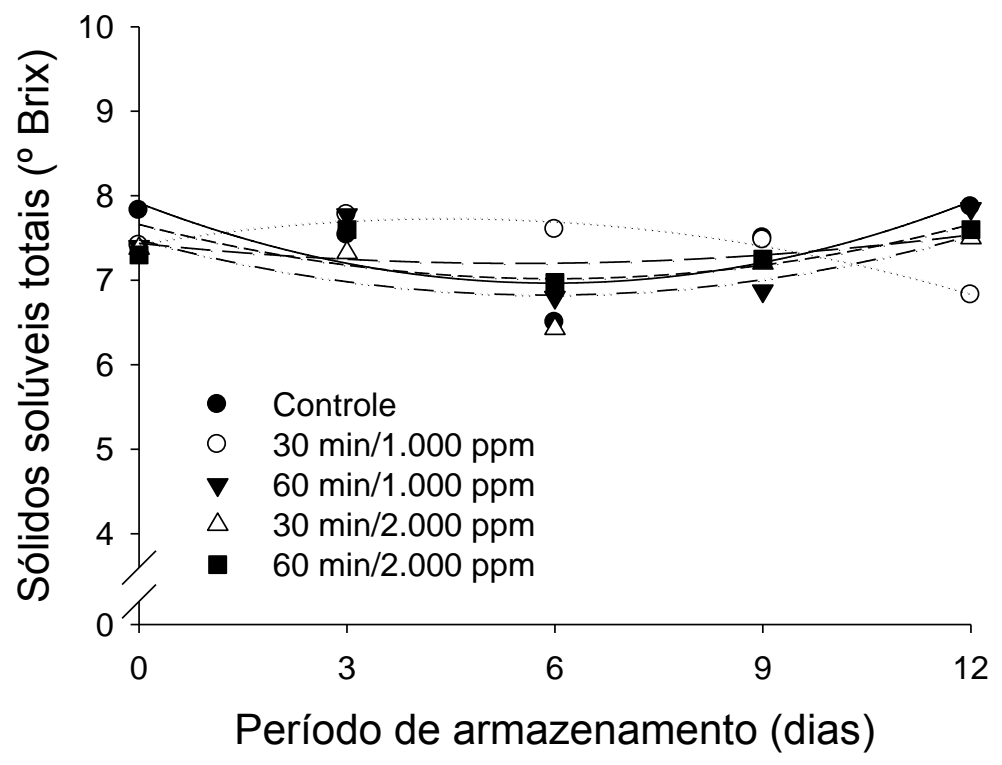

Figura 4- Sólidos Solúveis Totais ( ${ }^{\circ}$ Brix) em morangos ozonizados em diferentes combinações de concentração do gás (ppm) e período de exposição (min) e armazenados a 5 ${ }^{\circ} \mathrm{C}$. 
Tabela 4- Equações de regressão ajustadas e respectivos coeficientes de determinação referentes a Sólidos Solúveis Totais ( ${ }^{\circ}$ Brix) em morangos ozonizados em diferentes combinações de concentração do gás (ppm) e período de exposição (min) e armazenados a 5 ${ }^{\circ} \mathrm{C}$

\begin{tabular}{lcc}
\hline Tratamento & \multicolumn{1}{c}{ Equação de regressão ajustada } & $\mathrm{R}^{2}$ \\
\hline Controle & $\hat{y}=7,914-0,317^{n s} X+0,026^{n s} X^{2}$ & 0,65 \\
$1.000 \mathrm{ppm} / 30 \mathrm{~min}$ & $\hat{y}=7,430+0,139^{n s} X+0,016^{*} X^{2}$ & 0,96 \\
$1.000 \mathrm{ppm} / 60 \mathrm{~min}$ & $\hat{y}=7,661-0,214^{n s} X+0,018^{\mathrm{ns}} X^{2}$ & 0,37 \\
$2.000 \mathrm{ppm} / 30 \mathrm{~min}$ & $\hat{y}=7,479-0,222^{n s} X+0,019^{n s} X^{2}$ & 0,55 \\
$2.000 \mathrm{ppm} / 60 \mathrm{~min}$ & $\hat{y}=7,438-0,087^{n s} X+0,008^{n s} X^{2}$ & 0,28
\end{tabular}

ns Não Significativo a $5 \%$ de probabilidade pelo teste F.*Significativo a $5 \%$ de probabilidade pelo teste $\mathrm{F}$.

Salienta-se que os valores médios de sólidos solúveis totais permaneceram na faixa entre 6,80 e 7,80. Galletta et al. (1995) obtiveram teor de sólidos solúveis em morangos na faixa de $7-12 \%$ e Motero et al. (1996) na faixa de 4,5 a $15 \%$. Dentre os fatores que influenciam o teor de sólidos solúveis totais destacam-se fatores climáticos e os diferentes genótipos.

No que tange às variáveis acidez titulável e relação sólidos solúveis e acidez titulável (SST/AT), não obteve-se variação significativa em decorrência da interação tratamento e período de exposição ( $p>0,05)$. Os valores médios de acidez titulável obtidos neste trabalho são apresentados na Tabela 5 e permaneceram na faixa entre 0,77 e 0,92\% de ácido cítrico. Esses resultados são semelhantes aos observados por Nadas et al. (2003) e por Rahman et al. (2014). Os valores médios referentes a relação SST/AT permaneceram na faixa entre 7,65 e 9,64 (Tabela 6). 
Tabela 5 - Valores médios de acidez total titulável (\% de acido cítrico) em morangos ozonizados em diferentes combinações de concentração do gás (ppm) e período de exposição (min) e armazenados a $5^{\circ} \mathrm{C}$

\begin{tabular}{lccccc}
\hline \multicolumn{1}{c}{ Tratamento } & \multicolumn{5}{c}{ Período de armazenamento (dias) } \\
& $\mathbf{0}$ & $\mathbf{3}$ & $\mathbf{6}$ & $\mathbf{9}$ & $\mathbf{1 2}$ \\
\hline Controle & 0,92 & 0,92 & 0,94 & 0,91 & 0,84 \\
1.000ppm/30min & 0,83 & 0,91 & 0,81 & 0,87 & 0,85 \\
1.000ppm/60min & 0,87 & 0,81 & 0,82 & 0,89 & 0,87 \\
$2.000 \mathrm{ppm} / 30 \mathrm{~min}$ & 0,91 & 0,84 & 0,79 & 0,94 & 0,87 \\
$2.000 \mathrm{ppm} / 60 \mathrm{~min}$ & 0,82 & 0,93 & 0,77 & 0,86 & 0,92 \\
\hline
\end{tabular}

Tabela 6 - Valores médios de relação sólidos solúveis totais ( $\left.{ }^{\circ} B r i x\right)$ e acidez total titulável (\% acido cítrico) em morangos ozonizados em diferentes combinações de concentração do gás (ppm) e período de exposição (min) e armazenados a $5^{\circ} \mathrm{C}$

Tratamento

$$
\text { Período de armazenamento (dias) }
$$

\begin{tabular}{lccccc} 
& 0 & 3 & 6 & 9 & 12 \\
\hline Controle & 8,54 & 8,16 & 7,65 & 7,89 & 8,26 \\
$1.000 \mathrm{ppm} / 30 \mathrm{~min}$ & 8,97 & 8,61 & 8,91 & 8,57 & 8,02 \\
$1.000 \mathrm{ppm} / 60 \mathrm{~min}$ & 8,05 & 9,28 & 8,38 & 7,78 & 9,03 \\
$2.000 \mathrm{ppm} / 30 \mathrm{~min}$ & 8,08 & 8,81 & 8,22 & 7,73 & 9,64 \\
$2.000 \mathrm{ppm} / 60 \mathrm{~min}$ & 8,90 & 8,19 & 9,14 & 8,58 & 9,27 \\
\hline
\end{tabular}

Não houve variação significativa das variáveis saturação de cor (croma) e tonalidade de cor $\left(h^{\circ}\right)$ em decorrência da interação tratamento e período de armazenamento ( $\left.p>0,05\right)$. Na Tabela 7 encontram-se os valores médios de saturação de cor obtidos em morangos submetidos ou não a ozonização e armazenados na temperatura de $5{ }^{\circ} \mathrm{C}$ por 12 dias. Os valores permaneceram na faixa entre 22,17 e 37,54 .

Entretanto, obteve-se variação significativa $(\mathrm{p}<0,05)$, quando se analisou o efeito do período de armazenamento na variável saturação de cor, independentemente da exposição ou não ao gás ozônio. Ocorreu decréscimo da saturação de cor à medida que se elevou o período 
de armazenamento (Figura 5). De acordo com McGuire (1992) e Joromi et al. (2003), saturação de cor expressa a intensidade da cor, de tal forma que valores próximos a zero para cores neutras (cinza) e ao redor de 60 para cores vívidas.

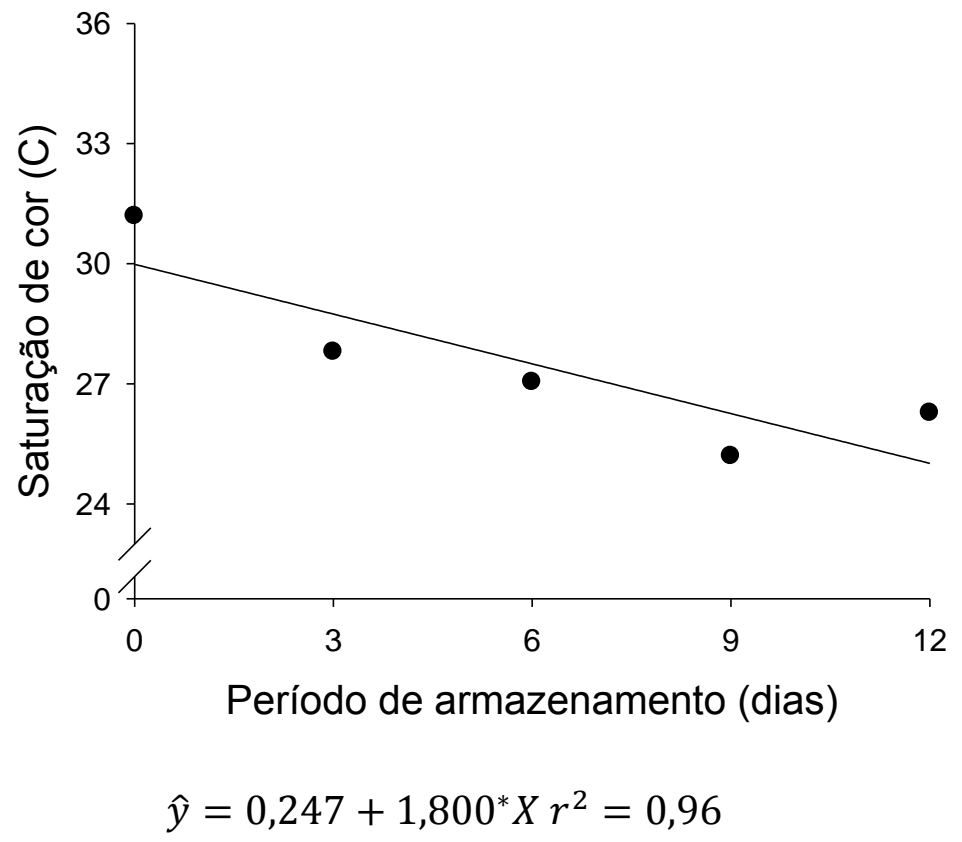

Figura 5 - Saturação de cor em morangos ozonizados em diferentes combinações de concentração do gás (ppm) e período de exposição (min) e armazenados a $5{ }^{\circ} \mathrm{C}$

Tabela 7 - Valores médios de saturação de cor (Croma) em morangos ozonizados em diferentes combinações de concentração do gás ( $\mathrm{ppm}$ ) e período de exposição (min) e armazenados a $5{ }^{\circ} \mathrm{C}$

\begin{tabular}{lccccc}
\hline \multirow{2}{*}{ Tratamento } & \multicolumn{5}{c}{ Período de armazenamento (dias) } \\
& 0 & 3 & 6 & 9 & 12 \\
\hline Controle & 31,76 & 23,37 & 25,32 & 24,37 & 22,29 \\
$1.000 \mathrm{ppm} / 30 \mathrm{~min}$ & 29,24 & 26,43 & 28,45 & 26,96 & 28,59 \\
$1.000 \mathrm{ppm} / 60 \mathrm{~min}$ & 27,78 & 26,27 & 28,06 & 24,64 & 28,04 \\
$2.000 \mathrm{ppm} / 30 \mathrm{~min}$ & 37,54 & 30,12 & 28,37 & 27,84 & 25,76 \\
$2.000 \mathrm{ppm} / 60 \mathrm{~min}$ & 29,63 & 32,81 & 25,02 & 22,17 & 26,70 \\
\hline
\end{tabular}


Encontram-se, na Tabela 8, os valores médios referentes a tonalidade de cor $(\mathrm{h})$ em morangos ozonizados em diferentes combinações de período de exposição (min) e concentração do gás (ppm) e armazenados a $5{ }^{\circ} \mathrm{C}$. Os valores de tonalidade de cor permaneceram na faixa entre $27,51^{\circ}$ e $39,03^{\circ}$. Valores de tonalidade de cor $\left(h^{\circ}\right)$ mais próximos de zero indicam frutos mais vermelhos, ao passo que valores mais próximos de $90^{\circ}$ indicam frutos com predominância de cor amarela.

Tabela 8 - Valores médios de tonalidade de cor $\left(h^{\circ}\right)$ em morangos ozonizados em diferentes combinações de concentração do gás (ppm) e período de exposição (min) e armazenados a 5 ${ }^{\circ} \mathrm{C}$

\begin{tabular}{lccccc}
\hline \multirow{2}{*}{ Tratamento } & \multicolumn{5}{c}{ Período de armazenamento (dias) } \\
& 0 & 3 & 6 & 9 & 12 \\
\hline Controle & 31,68 & 31,69 & 32,00 & 26,95 & 32,92 \\
$1.000 \mathrm{ppm} / 30 \mathrm{~min}$ & 32,30 & 34,58 & 26,38 & 29,46 & 27,51 \\
$1.000 \mathrm{ppm} / 60 \mathrm{~min}$ & 36,90 & 35,94 & 26,01 & 29,64 & 29,91 \\
$2.000 \mathrm{ppm} / 30 \mathrm{~min}$ & 39,03 & 31,34 & 27,01 & 28,91 & 29,14 \\
$2.000 \mathrm{ppm} / 60 \mathrm{~min}$ & 29,22 & 34,83 & 25,33 & 28,43 & 28,72 \\
\hline
\end{tabular}

No que se refere à diferença de cor $(\Delta \mathrm{E})$, Figura 6 , obteve-se diferença significativa em decorrência da interação entre tratamento e período de armazenamento $(\mathrm{p}<0,05)$. Verificou-se aumento da diferença de cor à medida que se elevou o período de armazenamento, sendo essa tendência mais acentuada nos frutos não ozonizados (tratamento controle). Ressalta-se que a variável diferença de cor foi obtida a partir dos valores de L, a e b, em um determinado período de armazenamento e os valores correspondentes a um padrão, que no presente trabalho, referiu-se aos frutos no início do armazenamento. Dessa forma, uma maior elevação da diferença de cor implica em um distanciamento mais pronunciado da cor inicial, comportamento observado nos frutos não ozonizados.

Encontram-se, na Tabela 9, as equações de regressão ajustadas e os respectivos coeficientes de determinação referentes a diferença de cor $(\Delta \mathrm{E})$ em morangos ozonizados em diferentes combinações de período de exposição (min) e concentração do gás (ppm) e armazenados a $5^{\circ} \mathrm{C}$. 


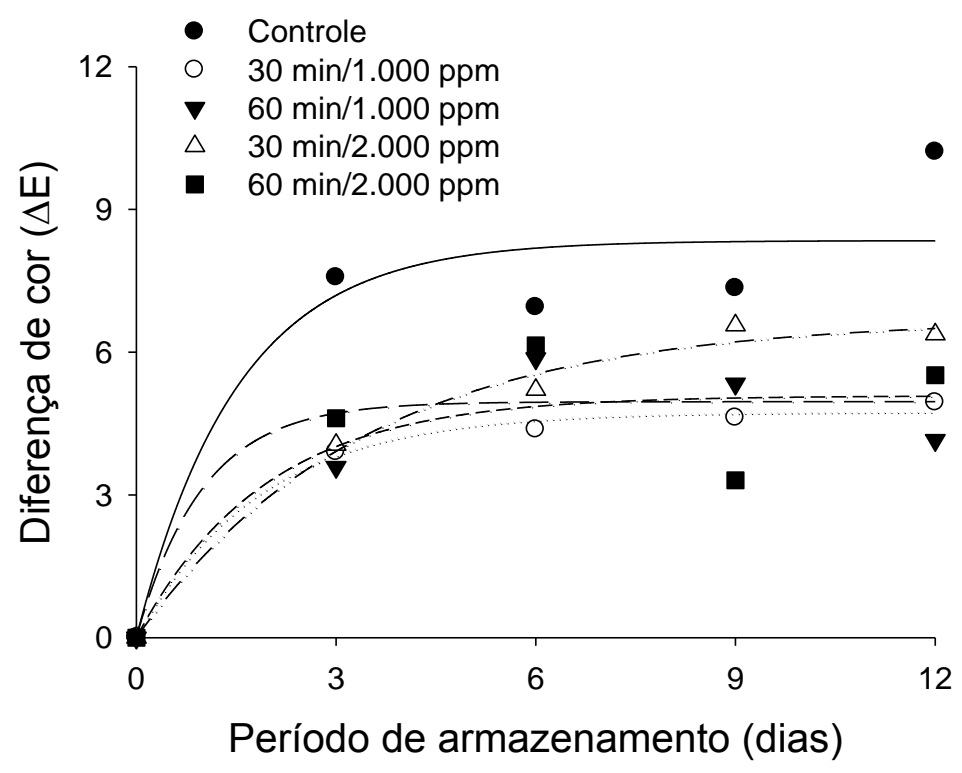

Figura 6 - Diferença de cor $(\Delta \mathrm{E})$ em morangos ozonizados em diferentes combinações de concentração do gás (ppm) e período de exposição (min) e armazenados a $5^{\circ} \mathrm{C}$.

Tabela 9- Equações de regressão ajustadas e respectivos coeficientes de determinação referentes a diferença de cor $(\Delta \mathrm{E})$ em morangos ozonizados em diferentes combinações de período de exposição (min) e concentração do gás (ppm) e armazenados a $5{ }^{\circ} \mathrm{C}$

\begin{tabular}{lcc}
\hline Tratamento & Equação de regressão ajustada & R2 \\
\hline Controle & $\hat{\mathrm{y}}=8,344\left(1-\mathrm{e}^{(-0,660 \mathrm{X})}\right)$ & 0,89 \\
$1.000 \mathrm{ppm} / 30 \mathrm{~min}$ & $\hat{\mathrm{y}}=4,745\left(1-\mathrm{e}^{(-0,546 \mathrm{X})}\right)$ & 0,99 \\
$1.000 \mathrm{ppm} / 60 \mathrm{~min}$ & $\hat{\mathrm{y}}=5,083\left(1-\mathrm{e}^{(-0,520 \mathrm{X})}\right)$ & 0,90 \\
$2.000 \mathrm{ppm} / 30 \mathrm{~min}$ & $\hat{\mathrm{y}}=6,696\left(1-\mathrm{e}^{(-0,293 \mathrm{X})}\right)$ & 0,99 \\
$2.000 \mathrm{ppm} / 60 \mathrm{~min}$ & $\hat{\mathrm{y}}=4,959\left(1-\mathrm{e}^{(-1,006 \mathrm{X})}\right)$ & 0,81 \\
\hline
\end{tabular}

Salienta-se que a cor é um importante atributo para a aquisição de um produto pelo consumidor e é importante a adoção de um método de conservação que amplie a vida de prateleira sem alterar esta característica. Segundo Calderon (2010) a deterioração da cor é também dependente de fatores como a variedade da fruta, umidade relativa, estágio de maturação e situações operacionais do processo de conservação. Farinha (2008) avaliou raízes de cenoura armazenadas em ambientes com diferentes umidades relativas. $\mathrm{O}$ autor observou que alteração de cor mais intensa à medida que a umidade relativa foi reduzida. Essa tendência foi associada a perda de água pelas raízes. Nesse sentido, o fato de ocorrer menor perda de água nos frutos ozonizados deve ter influenciado positivamente a variável diferença de cor. 


\section{CONCLUSÕES}

É possível concluir, a partir dos resultados obtidos, que a ozonização pode ser considerada uma importante alternativa para a manutenção da qualidade pós-colheita de morangos produzidos em sistema orgânico. Foi possível verificar nos frutos ozonizados menor percentual de perda de massa fresca e alteração de cor menos intensa ao longo do armazenamento. Além disso, quando se ozonizou os frutos nas concentrações de 1.000 e 2.000 ppm, e períodos de ozonização ao gás equivalentes a 60 e $30 \mathrm{~min}$, houve retardamento no decréscimo de vitamina C. Salienta-se que é fundamental que sejam avaliadas outras combinações de concentração e período de exposição ao gás em morango produzidos em sistema orgânico, de tal forma a comprovar a viabilidade técnica da ozonização nesse tipo de produto. 


\section{REVISÃO BIBLIOGRAFICA}

ADAY, M. S.; CANER, C. Individual and combined effects of ultrasound, ozone and chlorine dioxide on strawberry storage life. LWT - Food Science and Technology. v. 57, p. 344$355,2014$.

ALEXANDRE, E. M. C.; BRANDÃO, T. R. S.; SILVA, C. L. M. Efficacy of non-thermal technologies and sanitizer solutions on microbial load reduction and quality retention of strawberries. Journal of Food Engineering, v. 108, p. 417-426, 2012.

BRASIL MINISTÉRIO DA SAÚDE - Agencia Nacional de Vigilancia Sanitária. Métodos Físico Quimicas para análise de alimentos. Ministério da Saúde, p. 1018, 2005.

CALDERON, M.; M. Internal quality profile and influence of packaging conditions on fresh-cut pineapple. Universidade Lleida. Escola Técnica Superior de Enginyeria Agrária. Departament de Tecnologia de Alimentos. (menção PhD), p. (230). Espanha, 2010.

CANER, C.; ADAY, M. S.; DEMIR, M. Extending the quality of fresh strawberries by equilibrium modified atmosphere packaging. European Food Research and Technology, Berlin, v. 227, p. 1575-1583, 2008.

CARDOSO. L. M.; DEUS, V. A.; ANDRADE, V. C.; PINTO, N. A.V. Quallidade póscolheita de morangos cultivar Diamante, tratados com Cloreto de cálcio. Alim. Nutr. v. 23, n. 4, p. 583-588, 2012.

DOSTI,B.; GUZEL, Z.; GREENE, A. Effectiveness of ozone, heat and chlorine for destroying common food spoilage bacteria in synthetic media and biofilms. International Journal of Dairy Technology, v. 58, p. 19-24, 2005.

EMATER-DF. Empresa de Assistência Técnica e Extensão Rural do Distrito Federal. Produção Agropecuária 2011. http://www.emater.df.gov.br/ Acesso: 02 de maio 2014.

FAO, Food and Agriculture Organization of the United Nations. Food and Agricultural commodities production, http://faostat.fao.org/site/339/default.aspx. Acesso: 20 de janeiro 2015 .

FARINHA, L. R. L. Características físicas na perda da matéria fresca e evolução das propriedades reológicas e cor da cenoura cv. Brasília no armazenamento. Dissertação Universidade Federal de Viçosa (UFV). Viçosa, Minas Gerais, p. 111, 2008.

FINGER, L. F.; VIEIRA, G. Controle da perda pós-colheita de água em produtos hortícolas. Viçosa, Minas Gerais. Universidade Federal de Viçosa, p. 29 (Caderno Didáctico, v.19) 1997.

FRANCIS, F.J. The origin of $\tan ^{-1}$ a/b. Journal of Food Science, v. 40, p. 412, 1975.

FRANCO, G. Tabelas de composição química dos alimentos. São Paulo: Atheneu, 2002, $303 p$.

GALLETTA, G. J.; ENNS, J. M.; MASS, J. L. Strawberry cultivar responses to variations in planting time, stock, and mulches. HotScience, v. 31, p. 5, 1996. 
GRAHAM, D.M. Use of ozone for food processing. Food Technology, v. 6, n. 51, p. 72-75, 1997.

HELENO, F. F. Ozonização: Uma estratégia para remoção de resíduos de agrotóxicos em alimentos. 2013. 86 f. Tese (Doutorado em Agroquímica) - Universidade Federal de Viçosa. Viçosa - MG. 2013.

HENRIQUES, A.T.; BASSANI, V.L.; RASEIRA, M. do C.; ZUANAZZI, J.A. Antocianos e capacidade antioxidante de frutas. In: Simpósio Nacional do Morango, 2., Encontro De Pequenas Frutas E Frutas Nativas, 1., 2004, Pelotas. Anais... Pelotas: Embrapa Clima Temperado, 2004. p.271-282. (Documentos, 124).

HOLTZ, S., G.; Aplicação de ozônio e de revestimentos comestíveis em morangos (Fragaria ananassa Duch,) minimamente processados. Dissertação Pós-graduação em Microbiologia Agrícola Magister Scientiae Universidade Federal de Viçosa. Minas Gerais Brasil, 2006. p, 81.

JOMORI, M. L. L.; KLUGE, R. A.; JACOMINO, A. P.; TAVARES, S. Conservação refrigerada de lima ácida 'Tahiti': Uso de 1-metilciclopropeno, ácido giberélico e cera. Revista Brasileira de Fruticultura, Jaboticabal - SP, v. 25, n. 3, p. 406-409, 2003.

KADER, A. A.; D. M. BARRETT. Classification, composition of fruits and postharvest maintenance of quality. In: Barrett, D. M.; Laszlo, S.; Hosahalli, R. Processing Fruits. Boca Raton, 2005. . p. 3-22.

LAZAROVA, V.; SAVOYE, P.; JANEX, M. Advanced wastewater disinfection technologies: state of the art and perspectives. Water Science and technology, v. 40. p. 201213. 1999.

LITTLE, A. Off on a tangent. Journal of Food Science, Chicago, v.40, p.410-411, 1975.

MASKAN, M. Kinetics of colour change of kiwifruits during hot air and microwave drying. Journal of Food Engineering, v.48, p.169-175, 2001.

McGUIRE, R.G. Reporting of objective colour measurements. HortScience, Alexandria, v.27, p.1254-1255, 1992.

MCLELLAN, M.R.; LIND, L.R.; KIME, R.W. Hue angle determinations and stastistical analysis for multiquadrant hunter L, a, b data. Journal of Food Quality, v.18, n.3, p.235-240, 1995.

MONTERO, T. M.; MOLLÁ, E. M.; ESTEBAN, R. M.; ANDRÉU, F. J. L. Quality attributes of strawberry during ripening. Scientia Horticulturae, v. 65, p. 239-250, 1996.

NADAS, A.; OLMO, M.; GARCÍA, J. M. Growth of Botrytis cinerea and strawberry quality in ozone enriched atmospheres. Journal of Food Science, v.68, n.5, p. 1798-1802, 2003.

NOVAK, J.S.; YUAN, J.T.C. The Ozonation Concept: Advantages of Ozone Treatment and Commercial Developments. In: Tewari, G.; Juneja, V.K. (Eds.) Advances in Thermal and Non-Thermal Food Preservation. Ames: Blackwell Publishing, 2007, p.185-193. 
PALOU, L.; CRISOSTO, C. H.; SMILANICK, J. L.; ADASKAVEG, J. E.; ZOFFOLI, J. P. Effects of continuous $0.3 \mathrm{ppm}$ ozone exposure on decay development and physiological responses of peaches and table grapes in cold storage. Posharvest Biology and Technology, v. 24, p. 39-48, 2002.

PONCE, A.; BASTIANI, M.; MINIM, V.; VANETTI, M. Características físico-químicas e microbiológicas de morango minimamente processado. Ciência e Tecnologia de Alimentos, v.30, n.01, p. 113-118, 2010.

RADIN, B.; LISBOA, B.B.; WITTER, S.; BARNI, V.; REISSER JUNIOR, C.; MATZENAUER, R.; FERMINO, M.H. Desempenho de quatro cultivares de morangueiro em duas regiões climáticas do Rio Grande do Sul. Horticultura Brasileira, v.29, p.287-291, 2011.

RAHMAN, M. M; MONIRUZZAMAN, M.; AHMAD, M. R.; SARKER, B. C.; ALAM, K. M. Maturity stages affect the postharvest quality and shelf-life of fruits of strawberry genotypes growing in subtropical regions. Journal of the Saudi Society of Agricultural Sciences. p. 10, 2014.

RAILA, A.; LUGAUSKAS, A.; STEPONAVIČIUS, D.; RAILIENÉ, M.; STEPONAVIČIENE, A.; ZVICEVIČIUS, E. Application of ozone for reduction of mycological infection in wheat grain. Annals of Agricultural and Environmental Medicine, v. 13, n. 2, p. 287-294, 2006.

WU, J.; DOAN, H.; CUENCA, M.A. Investigation of gaseous ozone as an anti-fungal fumigant for stored wheat. Journal of Chemical Technology \& Biotechnology, v. 81, n. 7, p.1288-1293, 2006.

ZAMBOLIM, L.; COSTA. H. Manejo integrado de doenças do morangueiro. In: CARVALHO, S. P. (Coord.).Boletim do morango: cultivo convencional, segurança alimentar, cultivo orgânico. Belo Horizonte: CEASA Minas, 2005. p. 55-96. 